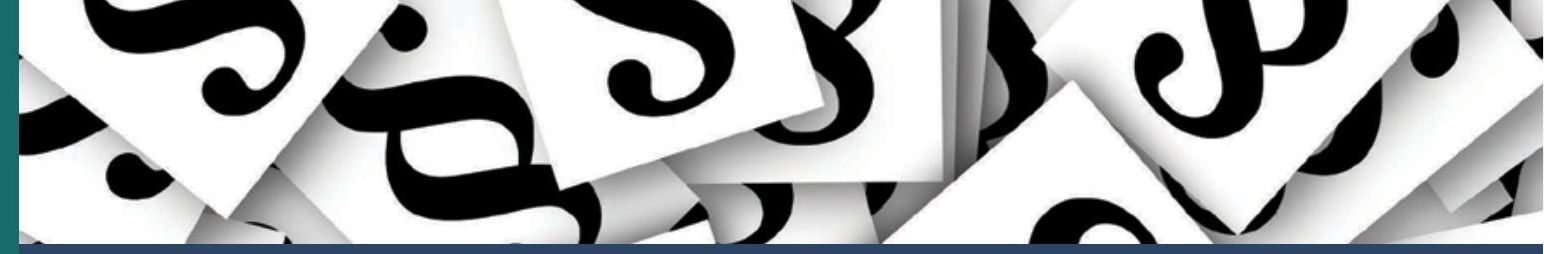

Aktualność

filozofii prawa Herberta Harta jako krytyki

pierwotnego pozyływizmu prawnego oraz jej otwartość

na koncepcję racjonalności praktycznej

Mariusz Leleno-Czarnak

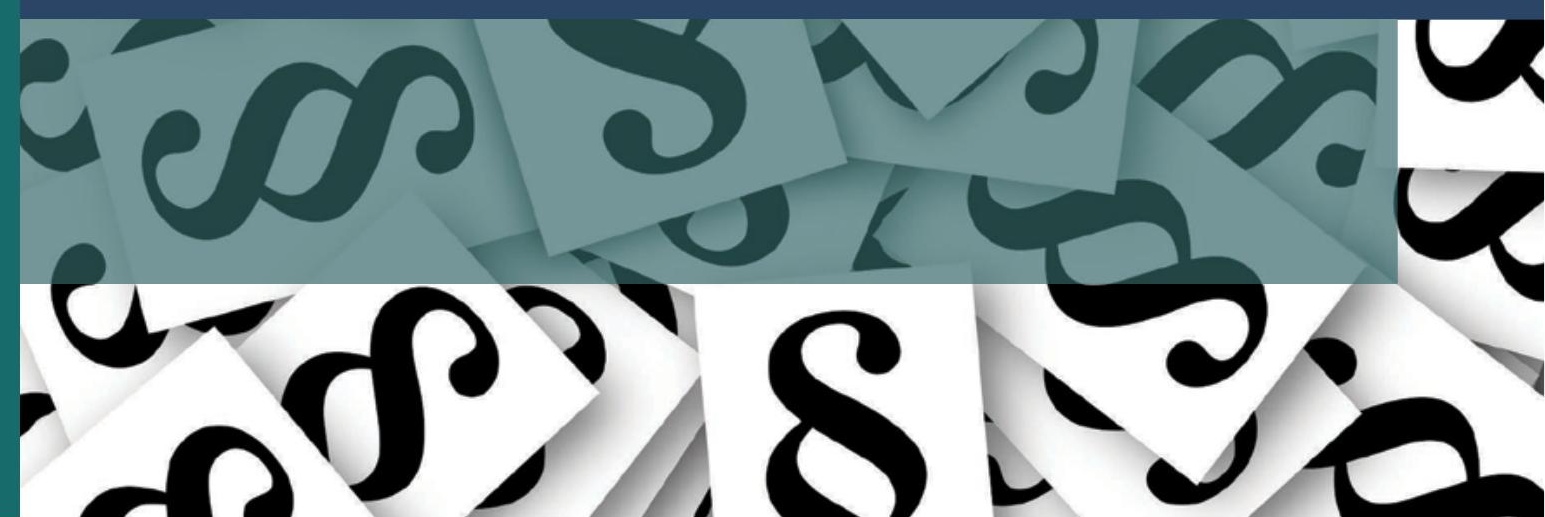





\section{Aktualność \\ filozofii prawa Herberta Harta \\ jako krytyki \\ pierwotnego pozytywizmu prawnego \\ oraz jej otwartość \\ na koncepcję racjonalności praktycznej}

\section{Mariusz Leleno-Czarnak}





\section{LIBER}

\section{Aktualność}

filozofii prawa Herberta Harta jako krytyki

pierwotnego pozyływizmu prawnego oraz jej otwartość

na koncepcję racjonalności praktycznej

Mariusz Leleno-Czarnak 
Mariusz Leleno-Czarnak

Aktualność filozofii prawa Herberta Harta jako krytyki pierwotnego pozytywizmu prawnego oraz jej otwartość na koncepcję racjonalności praktycznej

Recenzenci:

prof. dr hab. Maria Szyszkowska (WSM w Warszawie)

ks. prof. dr hab. Ryszard Moń (Akademia Teologiczna w Warszawie)

Projekt okładki:

Dominika Karaś

Ilustracja na okładce:

pixabay.com

Korekta językowa:

Małgorzata Najderska

Skład i łamanie:

Studio DTP Academicon | Patrycja Waleszczak

dtp@academicon.pl | dtp.academicon.pl

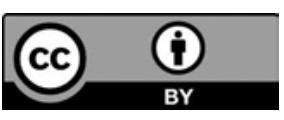

Publikacja jest udostępniona na licencji Creative Commons Uznanie autorstwa 4.0

Treść licencji jest dostępna na stronie: https://creativecommons.org/licenses/by/4.0/

Wydawnictwo Liberi Libri, 2021

www.LiberiLibri.pl

ISBN: 978-83-63487-49-2

DOI: $10.47943 /$ lib.9788363487492 
Dziękuję Panu Dr. Andrzejowi Waleszczyńskiemu za pomoc w wydaniu publikacji oraz Pani Mgr Joannie Ziajkowskiej za korekte podsumowania w języku angielskim. 



\section{Spis treści}

Wstęp 9

ROZDZIAŁ 1. NACZELNE TWIERDZENIA POZYTYWIZMU PRAWNEGO

15

1.1 Zagadnienia wprowadzające 15

1.2 Pierwotny (twardy) pozytywizm prawny 19

1.3 Podstawy wyrafinowanego (miękkiego) pozytywizmu prawnego 26

ROZDZIAŁ 2. WYBRANE ZAGADNIENIA POLSKIEGO SYSTEMU PRAWNEGO

JAKO ILUSTRACJA FILOZOFII PRAWA HERBERTA HARTA 35

2.1 Wspólna geneza europejskich kultur prawnych 36

2.2 Język prawny a prawniczy 38

2.3 Przykłady oczywistej otwartości struktury polskiego języka prawnego

44

ROZDZIAŁ 3. ELEMENTY FILOZOFII PRAWA HERBERTA HARTA 47

3.1 Uwagi wprowadzające 48

3.2 Specyfika rozumienia przez Herberta Harta pojęć prawnych $\quad 53$

3.3 Prawo jako związek reguł pierwotnych i wtórnych $\mathbf{5 5}$

3.4 Związek prawa i moralności w filozofii Herberta Harta 63

3.5 Koncepcja minimalnej treści prawa natury 74

3.6 Aktualność filozofii prawa Herberta Harta 79

ROZDZIAŁ 4. KONCEPCJA ROZUMNOŚCI PRAKTYCZNEJ JAKO UZUPEŁNIENIE POZYTYWIZMU PRAWNEGO HERBERTA HARTA $\mathbf{8 7}$

4.1 Zarys koncepcji tzw. nowej teorii prawa naturalnego 87

4.2 Rozumność praktyczna jako konieczny element teorii prawa pozytywnego 94

Zakończenie 99

Bibliografia 103

Summary 107 



\section{Wstęp}

Monografia wydana została staraniem wydawnictwa związanego z Uniwersytetem Kardynała Stefana Wyszyńskiego, który jako następca Akademii Teologii Katolickiej ma szczególne zasługi dla rozwoju i zachowania filozofii prawa w Polsce. Ta dziedzina wiedzy była bowiem w czasach PRL-u wyrugowana $\mathrm{z}$ uniwersytetów jako niezgodna $\mathrm{z}$ marksizmem i nienaukowa. Jedynymi ośrodkami, gdzie uprawiano oficjalnie filozofię prawa, były w tym czasie Akademia Teologii Katolickiej oraz Katolicki Uniwersytet Lubelski. Niniejsza publikacja wpisuje się zatem w tradycję uniwersytetu, w ramach działalności którego jest pisana.

Temat wybrany został z uwagi na doświadczenia zawodowe autora i rolę pozytywizmu prawnego $\mathrm{w}$ kształtowaniu sposobu myślenia prawników oraz w praktyce sądowej. Bezpośrednią inspiracją były dyskusje prowadzone z doktorem Andrzejem Waleszczyńskim na zajęciach ze Współczesnych nurtów filozofii prawa.

Celem monografii jest przedstawienie współczesnego rozumienia pojęcia „pozytywizm prawny”. Przede wszystkim wskazać należy na aktualność tego sposobu myślenia. Na gruncie opisu jest to bowiem najbardziej trafne ujęcie zjawisk prawych. Ponadto jest to filozofia, która w największym stopniu formuje prawników, a co za tym idzie, kreuje naszą kulturę. Krytyczna ocena pozytywizmu prawnego ma zatem doniosły wymiar praktyczny. Jest ona konieczna $\mathrm{z}$ uwagi na niewystarczalny charakter tego sposobu myślenia o prawie.

Uzupełnieniem zarysowanego wyżej celu jest propozycja przedstawienia podstawowych założeń tzw. nowej teorii prawa naturalnego opartej na koncepcji racjonalności praktycznej - w kształcie nadanej jej głównie przez Johna Finnisa - jako teorii wzbogacającej pozytywizm prawny. Jest to zatem próba przezwyciężenia klasycznej dychotomii pozytywizmu prawnego oraz prawa natury.

Wskazać należy na potrzebę podkreślenia różnicy pomiędzy pierwotnym (twardym) pozytywizmem prawnym Johna Austina a wyrafinowanym (miękkim) pozytywizmem prawnym Herberta Harta. Myśl tego drugiego mieści się w tej samej tradycji filozoficznej, co publikacje Austina. Dokonana 
przez Harta krytyka pierwotnego pozytywizmu prawnego ma zatem znaczenie doniosłe, spowodowała bowiem zmianę znaczenia pojęcia „pozytywizm prawny". Dorobek Harta sprawił, że nie jest już możliwy powrót do założeń pierwotnego pozytywizmu prawnego. Innymi słowy, Hart niepodważalnie i, co ważne, na gruncie metody pozytywizmu prawnego, wykazał błędy filozofii Austina.

Ma to znaczenie istotne, albowiem pomimo tego, że polski system prawny wykracza poza Austinowską koncepcję, to z doświadczeń autora niniejszej publikacji wynika, że wpływy pierwotnego pozytywizmu prawnego na myślenie prawnicze są wciąż ogromne, co nie znajduje już uzasadnienia we współczesnej filozofii. Z publikacji Harta płynie postulat większej otwartości sędziów na pozaprawne systemy normatywne - nie w tym sensie, że norma prawna miałaby być niżej w hierarchii od normy etycznej, ale w tym, że nie sposób zrozumieć treści normy prawnej bez odniesienia do innych systemów normatywnych.

$\mathrm{Z}$ uwagi na fundamentalną rolę pozytywizmu prawnego w kształtowaniu polskiej kultury prawnej, niezwykle ważne jest wykazanie, że z pozytywizmu prawnego płynie zarówno postulat uwzględnienia przez metodę prawoznawstwa zasad prawa, jak i prawa natury (choć w szczątkowej formie), co - na gruncie pozytywizmu prawnego - było błędem przed zmianami dokonanymi za sprawą Herberta Harta.

Istotne jest ponadto ukazanie granic, których pozytywista prawny przekroczyć nie jest zdolny, a zatem wskazanie ograniczeń tego sposobu myślenia, a w konsekwencji poszukiwanie sposobów na jego uzupełnienie.

Niniejsza publikacja uzasadnia tezę o aktualności pozytywizmu prawnego - pomimo jego ograniczeń - w formie, jaka nadana mu została przez Herberta Harta. Wiele problemów poruszanych na gruncie filozofii prawa zostało jedynie zasygnalizowanych. Przede wszystkim należy wskazać, że interesujące uzupełnienie niniejszego tekstu stanowiłaby analiza społecznego pozytywizmu Josepha Raza ${ }^{2}$. Wskazać ponadto należy, że obecne w publikacji nawiązania do polskiego sytemu prawnego stanowią ilustracje poglądów Herberta Harta, a ich celem jest wykazanie prawdziwości tezy o aktualności jego filozofii, nie zaś całościowa analiza obowiązującego w Polsce prawa.

1 Zob. A. Waleszczyński, Ronalda Dworkina teoria interpretacji i jej rola w filozofii prawa i polityki, „Politeja” 2006, t. 2, nr 6, s. 312.

2 "Społeczny” pozytywizm prawny w odniesieniu do filozofii Raza zaproponował na gruncie polskiej filozofii prawa dr Kozłowski, podkreślając fundamentalną rolę tzw. tezy społecznej w poglądach Raza. Zob. T. Kozłowski, Społeczny pozytywizm Josepha Raza, „Studia Iuridica” 1998, t. XXXVI, s. $93-101$. 
Metoda zastosowana przy pisaniu niniejszej monografii wykracza poza ramy metody analityczno-syntetycznej. Filozofia Harta została odniesiona do podstawowych cech polskiego sytemu prawnego w celu ukazania jej doniosłego i aktualnego znaczenia dla namysłu nad filozofią prawa w Polsce. W publikacji wykorzystane zostały również elementy wiedzy psychologicznej, co podyktowane jest empirycznym ukierunkowaniem Harta. Łatwiej bowiem polemizować $\mathrm{z}$ autorem na tym samym polu, niż wprowadzać całkowicie odmienną perspektywę, która zostałaby przez niego odrzucona.

Rozdział pierwszy stanowi wprowadzenie w tematykę filozoficzno-prawną. Ukazana w nim będzie różnica pomiędzy pierwotnym a wyrafinowanym pozytywizmem prawnym. Wprowadzenie to jest konieczne dla zrozumienia teorii Herberta Harta.

$\mathrm{W}$ rozdziale drugim przedstawione zostaną istotne z punktu widzenia filozofii Harta elementy polskiego sytemu prawnego. Omówione będą powody, dla których uprawnione jest łączenie namysłu nad systemami prawa kontynentalnego oraz Common Law. Następnie przedstawione zostanie rozróżnienie pomiędzy językiem prawnym a prawniczym, co jest jednym z fundamentalnych zagadnień filozofii prawa. W celu ukazania trafności opisowej warstwy filozofii Harta omówione zostaną podstawowe przykłady otwartości polskiego języka prawnego.

Rozdział trzeci stanowić będzie zasadniczą część monografii, ukazującą poglądy filozoficzno-prawne Herberta Harta. Rozpoczną go uwagi wprowadzające. Podyktowane jest to potrzebą korekty poglądów, której dokonał Hart w replice na krytykę Dworkina. Koncepcja Harta zostaną ukazane przez pryzmat tej repliki. Przedstawiona zostanie również specyfika rozumienia przez Harta pojęć prawnych, jako że znacznie odbiega ona od tej przyjętej w Polsce. W szczególności inny jest pogląd Harta na istotę definicji w prawie. Następnie omówiona zostanie koncepcja prawa jako związku reguł pierwotnych i wtórnych. W dalszych podrozdziałach rozdziału trzeciego przedstawione będą związki prawa i moralności oraz koncepcja minimalnej treści prawa natury jako koniecznie wspólnego zakresu prawa i moralności. Rozdział ten zawierał będzie również omówienie najważniejszych wniosków płynących z analizy filozofii Harta odniesionych do realiów polskiego sytemu prawnego, a także krytyczny komentarz autora niniejszego tekstu.

Rozdział czwarty ukaże możliwość uzupełnienia filozofii Harta przez koncepcję racjonalności praktycznej stanowiącą rdzeń tzw. nowej teorii prawa naturalnego. W tym celu przedstawiony zostanie zarys tej koncepcji, a następnie wskazane będą argumenty przemawiające za koniecznością 
uwzględnienia teorii rozumności praktycznej przez prawoznawstwo, a zatem połączenia prawoznawstwa z elementami teorii moralności.

Zakończenie wskaże na powody, dla których filozofia prawa Herberta Harta oraz Nowa Teoria Prawa Naturalnego mogą być rozumiane jako koncepcje uzupełniające się.

Wskazać należy, że przykłady Harta odnoszące się do brytyjskiego sytemu prawnego lub mające charakter ogólny zostały w niniejszej publikacji zastąpione lub uzupełnione przykładami odnoszącymi się do obowiązujących przepisów prawa polskiego.

Dodać także należy, że w niniejszej monografii zrezygnowano z rozróżnienia na „prawo natury” oraz "prawo naturalne”. Jego zachowanie w odniesieniu do nowej teorii prawa naturalnego jest dyskusyjne z uwagi na specyficzne rozumienie na jej gruncie metafizyki oraz jej roli w uzasadnianiu poglądów filozoficznych. Zrezygnowano również z przyjętego w części literatury przedmiotu określania koncepcji prawno-naturalnych mianem „jusnaturalizmu”, a także z konwencji językowej, zgodnie z którą legal positivism tłumaczy się jako „pozytywizm prawniczy”, nie zaś „prawny”.

Abstrahując od wywodu dotyczącego pozytywizmu prawnego, warto dla celów poznawczych sformułować tezę odmienną do wynikającej z tej dziedziny filozofii prawa. Mianowicie, prawo jest częścią kultury nakierowaną na realizację idei sprawiedliwości. Jest zatem realizacją projektu ludzkiego umysłu zwróconego ku wartościom wyższym. W tym ujęciu prawo nie służy wyłącznie realizacji celów biologicznych czy utylitarnych, ale porządkuje życie społeczne tak, by urzeczywistnić ideę sprawiedliwości. Interesującym jest to, że proces kreacji idei prawa zawiera dwa elementy. Pierwszy, oczywisty, polega na próbie zdefiniowania ideału. Drugi, mniej oczywisty, polega na identyfikacji symbolicznej, czyli na tym, z jakiej perspektywy pragniemy, by oceniane były postępy naszego dążenia ku sprawiedliwości ${ }^{4}$. Możliwych perspektyw jest wiele. Trzy najważniejsze to kantyzm, tomizm i pozytywizm prawny.

W przywołanym sensie kantyzm i tomizm są perspektywami zbliżonymi. Ich przedstawiciele spierać się będą o charakter ideałów ${ }^{5}$, ale nie

3 Zob. A. Kobyliński, Problem fundamentu praw człowieka w myśli Norberta Bobbia, w: R. Moń, A. Kobyliński (red.), Prawa człowieka i świat wartości, Warszawa 2011, s. 208.

4 Identyfikacja symboliczna jest pojęciem używanym na gruncie psychoanalizy, w szczególności tej nawiązującej do tradycji Jacques’a Lacana. Wykorzystywane jest ono jednak także przez przedstawicieli takich nauk jak filozofia czy socjologia.

5 Należy pamiętać, że: „Nonsensem jest spotykane twierdzenie, że etyka sformułowana przez Kanta nie jest etyką wartości, lecz etyką obowiązku i powinności. Wszak obowiązek, czynienie zadość powinności bezwzględnej stanowi fundamentalną wartość”. M. Szyszkowska, Etyka, Białystok 2010, s. 59-60. 
o to, że prawo powinno być ich realizacją. Co więcej, chociaż założenia ich rozumowań nie są możliwe do pogodzenia, to wnioski z nich płynące wydają się, co do zasady, tożsame. Pozytywizm prawny powszechnie uznawany jest za perspektywę całkowicie odmienną. Istotne jest to, że w procesie praktycznych działań zarówno kantysta, jak i tomista musi wiedzieć, czym jest pozytywizm prawny, jakie są jego zalety oraz ograniczenia. Jest on bowiem na tyle silnie wpisany w europejską kulturę prawną, że każdy z nas świadomie lub nie operuje pojęciami pozytywizmu prawnego, nawet jeśli deklaruje inną postawę. Warto zatem uświadomić sobie rolę pozytywizmu prawnego we współczesnej kulturze. Tylko tak bowiem możliwe jest kreowanie innej niż pozytywistyczna wizji świata. Należy mieć również na uwadze, że uprawnione są twierdzenia, w myśl których ograniczenia pozytywizmu prawnego w swoisty sposób legitymizują teorie prawa natury. Bezsprzecznie przykładem tego jest koncepcja minimalnej treści prawa natury. Szczegółowa analiza myśli Harta wskazuje jednak, że mechanizm ten jest dalece szerszy, czego ilustracją jest próba ukazania w niniejszej publikacji zarysów nowej teorii prawa naturalnego opartej na koncepcji racjonalności praktycznej jako uzupełnienia wyrafinowanego pozytywizmu prawnego. 



\section{Naczelne twierdzenia pozytywizmu prawnego}

Celem niniejszego rozdziału jest wprowadzenie czytelnika w tematykę filozoficzno-prawną, a w szczególności w założenia koncepcji pozytywizmu prawnego. W tym celu w podrozdziale 1.1 ukazana zostanie pokrótce różnorodność koncepcji filozoficzno-prawnych.

W podrozdziale 1.2 przedstawione zostaną założenia pozytywizmu prawnego pierwotnego (twardego) oraz jego rola we współczesnej praktyce sądowej. Dla pełnego zrozumienia tego nurtu przedstawione będą, w zarysie, przyczyny jego rozwoju oraz różnorodność mieszczących się pod tym pojęciem stanowisk.

W podrozdziale 1.3 opisane zostaną założenia wyrafinowanego (miękkiego) pozytywizmu prawnego na tle rozwoju filozofii języka. Filozofia Herberta Harta jest bowiem wynikiem przewrotu językowego i bez jego omówienia nie sposób jej zrozumieć.

\subsection{ZAGADNIENIA WPROWADZAJĄCE}

Rdzeń pozytywizmu prawnego od czasu sformułowania jego założeń w XIX w. przez Johna Austina stanowi odpowiedź na problem natury etycznej. Mianowicie, czym jest norma prawa stanowionego i jaki jest jej 
stosunek do normy etycznej. Nie znając odpowiedzi na powyższe pytanie, nie sposób określić granic etyki, a co za tym idzie, nie jest możliwym wykazanie zasadności jakiejkolwiek krytyki porządku prawnego z pozycji etycznych.

Wskazanie głównych założeń pozytywizmu prawnego podyktowane jest względami natury praktycznej. Jest to bowiem koncepcja najsilniej oddziałująca na środowisko prawnicze. Wystarczy powiedzieć, że na jednym z najlepszych w Polsce wydziałów prawa założenia pozytywizmu prawnego wpajane są studentom przez pierwsze cztery lata studiów, niemal jako dogmat. Dopiero na ostatnim roku studiów studenci zapoznawani są z innymi koncepcjami filozoficznymi.

Szczególnie istotna z punktu widzenia etyki jest ewolucja pozytywizmu prawnego od tzw. pozytywizmu prawnego twardego, przez który rozumie się przede wszystkim teorię nakazową Johna Austina (który w skrócie rozumiał prawo jako nakaz suwerena zabezpieczony przymusem państwa) do tzw. pozytywizmu prawnego miękkiego wypracowanego przez Herberta Harta, który uznał, że Austinowska norma prawna jest niewystarczająca do opisu rzeczywistości prawnej. Dla Harta prawem jest związek reguł pierwotnych i wtórnych. Przy czym - co zostanie wyjaśnione w dalszym toku wywodu - reguły wtórne mieszczą w sobie minimum prawa natury, które oparte jest na prostej obserwacji, a mianowicie, że wszyscy dążymy do przetrwania. Prawo zatem nie może stać temu dążeniu na przeszkodzie. Twierdzenie o minimalnej treści prawa natury przybliża współczesny pozytywizm prawny do teorii prawno-naturalnych. Zaciera się zatem wielowiekowa dychotomia między wskazanymi sposobami myślenia o prawie. Niektórzy autorzy wręcz formułują pogląd o śmierci pozytywizmu prawnego z uwagi na odejście od jego pierwotnych założeń'.

Krytyka pozytywizmu prawnego będzie przedmiotem dalszych rozważań. Należy jednak zauważyć, że słuszną wydaje się myśl o możliwości zaistnienia konsensusu pomiędzy przedstawicielami teorii prawno-naturalnych i pozytywistycznych ${ }^{2}$.

Jako że nie sposób zrozumieć pozytywizmu prawnego bez odniesienia do koncepcji prawno-naturalnych, konieczne jest krótkie omówienie tych stanowisk, jak też wskazanie na ich zróżnicowanie.

1 Por. L. Morawski, Pozytywizm „twardy”, pozytywizm „miękki” i pozytywizm martwy, „Ius et Lex” 2003 , t. 1, s. 320-345.

2 Słowo „pozytywizm” użyte jest w niniejszej publikacji w znaczeniu „pozytywizm prawny”. Pozytywizm jako stanowisko ogólnofilozoficzne nie jest jej przedmiotem. 
Należy wskazać, że zwolennicy prawa natury uważają, że normy prawa stanowionego podlegają normom wyższego rzędu, czy to moralnym, czy też innego rodzaju. Ową supremację wywodzi się w ogromnej większości albo z twierdzeń ontologicznych, jak w teorii tomistycznej, albo twierdzeń epistemologicznych, jak w teorii kantowskiej.

Klasycznym i powszechnie znanym jest twierdzenie Tomasza z Akwinu: lex naturalis nihil aliud est quam participatio legis aeternae in rationali creatura. Innymi słowy, prawo naturalne jest w tej koncepcji odciśnięciem myśli Boga w stworzeniu rozumnym. Natomiast prawo stanowione wynika $\mathrm{z}$ prawa naturalnego $\mathrm{w}$ dwojaki sposób: przez dedukcję i przez dookreślenie (determinatio). W przypadku determinatio, ogólna, stała i niezmienna idea jest dookreślana w wyniku interpretacji ${ }^{3}$.

Nie zagłębiając się w szczegóły, należy stwierdzić, że teoria tomistyczna - w jej klasycznej interpretacji - wymaga przyjęcia za prawdziwe założeń realizmu poznawczego oraz utożsamienia bytu z powinnością.

Kant natomiast zaprzeczył temu, że to w bycie znajduje się podstawa poznania pewnego. Odnalazł ją w podmiocie poznającym, co doprowadziło m.in. do rozgraniczenia przez niego sfery bytu i powinności. Moralnym jest dla Kanta zachowanie kierowane przez wolną wolę (oderwaną od popędów - działającą wyłącznie z czystego obowiązku). Istotnym jest, że owa wolna i zarazem dobra wola musi działać zgodnie z obiektywnym imperatywem (w języku kantowskim kategorycznym - czy w innej formie - praktycznym). Wynika on nie z celu danego czynu, ale z samej formy i zasady. Nie ma tu miejsca na szczegółowe omawianie teorii Kanta, warto natomiast zauważyć, że podstawą moralności jest dla niego autonomiczny podmiot działający z czystego obowiązku, zaś prawem natury nazywał nakazy rozumu praktycznego w sferze noumenalnej, nie zaś w sferze fenomenów. W tej ostatniej funkcjonują normy prawa pozytywnego ${ }^{4}$.

Istotnym jest, że w Kantowskiej koncepcji prawo stanowione (pozytywne) stwarza warunki zaistnienia czynu moralnego, albowiem prawo pozytywne zapewnia każdemu tę samą sferę wolności, a jak wiadomo, czyn jako moralny lub nie rozważany może być wyłącznie w sytuacji wolnego wyboru. W tym sensie prawo pozytywne jest warunkiem moralności. Prawo pozytywne bowiem (w sferze fenomenów) gwarantuje wolność, którą Kant wyraźnie odróżnia od samowoli panującej w stanie przedprawnym.

3 Por. J. Finnis, Prawo naturalne i uprawnienia naturalne, Warszawa 2001, s. 319.

4 Por. M. Zirk-Sadowski, Wprowadzenie do filozofii prawa, Kraków 2000, s. 35-45. 
Należy również podkreślić, że z punktu widzenia historii filozofii, sformułowania "prawa natury” nie można utożsamiać z prawem niezmiennym. Koncepcje prawa natury o zmiennej treści zostały stworzone, niezależnie, przez Rudolfa Stammlera oraz Leona Petrażyckiego (spór o pierwszeństwo pozostał nierozstrzygnięty). Systemy te różnią się diametralnie, łączy je natomiast przekonanie o zmienności norm prawa natury, które winny być dostosowane do warunków danej epoki ${ }^{5}$.

Najwybitniejszym zaś przedstawicielem nurtu prawa natury o zmiennej treści jest Gustav Radbruch. Stworzył on na gruncie neokantyzmu koncepcję filozoficzną, która obok pozytywizmu prawnego miała największy wpływ na praktykę sądowniczą XX w. Wystarczy wspomnieć, że w oparciu o jego koncepcję uzasadniano prawomocność procesów norymberskich. Ponadto tzw. „formuła Radbrucha” wykorzystywana była przez Federalny Trybunał Konstytucyjny w odniesieniu do obowiązywania prawa nazistowskiego, a także później - w latach '90 - w toku rozliczania przeszłości NRD'6.

Ponadto nie należy mylić prawa natury o zmiennej treści z wywodzącymi się z tomizmu dynamicznymi koncepcjami prawa natury, wedle których niezmienny pozostaje rdzeń normy, zmianie ulega jedynie jej interpretacja.

Odrębnym nurtem są koncepcje tzw. nowego prawa natury, których najbardziej znanym przedstawicielem jest John Finnis7. Stanowią one interpretację filozofii Tomasza $\mathrm{z}$ Akwinu, podkreślając rolę rozumności praktycznej jako źródła metody prawno-naturalnej. Co istotne, sprzeciwiają się one wyprowadzaniu twierdzeń o powinnościach z twierdzeń dotyczących realnie istniejącej rzeczywistości. W rozumieniu ich przedstawicieli prawo natury jest metodą pozwalającą wskazać racjonalne cele ludzkiej woli za pomocą oczywistych i niewywiedzionych pierwszych zasad rozumności praktycznej ${ }^{8}$. Zagadnienie rozumności praktycznej będzie przedmiotem dalszej analizy w rozdziale 4 .

5 M. Szyszkowska, Zarys europejskiej filozofii prawa, Białystok 2004, s. 78-79.

6 Por. M. Zirk-Sadowski, Wprowadzenie do filozofii prawa, s. 173.

7 Zob. J. Finnis, Prawo naturalne i uprawnienie naturalne.

8 Ibidem, s. 24, 116. 


\subsection{Pierwotny (TWARdy) POZytywizm PRAWNy}

Tak zwany twardy pozytywizm prawny, zwany także pierwotnym, dziś ma znaczenie głównie jako punkt odniesienia dla późniejszych koncepcji. Jest on odpowiedzią na XIX-wieczny system sprawowania władzy, w którym władza królewska, a co za tym idzie - tradycja feudalna - ustępowała miejsca aparatowi biurokratycznemu, koniecznemu $\mathrm{z}$ uwagi na poszerzenie kompetencji państwa wynikające $\mathrm{z}$ rewolucji przemysłowej. Dla tworzenia prawa miało to takie konsekwencje, że relacje społeczne, jako główny czynnik prawotwórczy, ustąpiły miejsca racjonalnemu aparatowi państwowemu kierującemu się zasadami racjonalności instrumentalnej. Nowy zaś sposób uchwalania norm prawa stanowionego skutkował swoistym rozłączeniem źródeł prawa pozytywnego oraz norm moralnych, które w systemie feudalnym były nierozłączne. W literaturze pojawia się zatem pogląd o usamodzielnieniu się prawa względem innych części kultury ${ }^{9}$. Tradycyjnie przyjmuje się, że wraz z rozwojem biurokratycznego aparatu państwowego także uprawnienie do stosowania przymusu zaczęto przypisywać wyłącznie państwu. Oczywiście próby wprowadzenia dominacji państwa w dziedzinie stosowania przemocy podejmowane były co najmniej od czasów rzymskich. Niemniej dopiero w czasach pozytywizmu prawnego udało się ten postulat omnipotencji państwa w dziedzinie przymusu w pełni usankcjonować teorią filozoficzną.

Wskazane wyżej zmiany doprowadziły do stworzenia nowego sposobu myślenia o prawie. Zaczęto je postrzegać jako „fakt”10, którego poznanie zapewnia analiza samego aktu prawodawczego.

Drugim niezmiernie ważnym dla powstania pozytywizmu prawnego impulsem było usamodzielnienie się prawoznawstwa jako nauki o własnym systemie pojęć zaczerpniętym z prawa rzymskiego. Usamodzielnienie to oraz postrzeganie prawa jako faktu, stanowiły podstawę, na której wypracowana została metoda formalno dogmatyczna utożsamiana z pozytywizmem prawnym lub, zdaniem wielu badaczy, stanowiąca jego najważniejszy element.

$\mathrm{Na}$ metodę formalno-dogmatyczną składają się dwa elementy. Po pierwsze, rozumienie aktu prawodawczego jako aktu woli suwerena pozostającego poza jakąkolwiek krytyką. Uznawany jest on za dogmat. Po drugie,

9 M. Zirk-Sadowski, Wprowadzenie do filozofii prawa, s. 174-175.

10 Traktowanie prawa jako faktu tłumaczy nazwę „pozytywizm prawny” i stanowi konsekwencję programu sformułowanego przez Augusta Comte’a. Nie jest zatem prawdziwym twierdzenie, że pozytywizm prawny nie ma punktów wspólnych z pozytywizmem znanym z filozofii ogólnej. 
uznanie, że wszelkie operacje myślowe dokonywane na materiale prawnym mają charakter wyłącznie formalny. Prawo jest systemem w rozumieniu logiki klasycznej, a zatem jest spójne i zupełne. Wszelka interpretacja norm prawnych oraz ich wykładnia ogranicza się do operacji logicznych, które nie dodają żadnych nowych treści. Innymi słowy, na drodze formułowania wniosków z przesłanek - jakimi jest wola suwerena - nie następuje żaden proces twórczy. Owe operacje logiczne przeprowadzane są na drodze wnioskowań prawniczych, czy też metod wykładni wyprowadzonych z twierdzeń logiki klasycznej. Dla przykładu można wymienić wnioskowania: a maiori ad minus, a minori ad maius, a contrario, czy takie elementy wykładni jak: lex posterior derogat legi priori, lex specialis derogat legi generali itd.

Należy podkreślić, że zgodnie z klasycznymi twierdzeniami pozytywizmu, w systemie prawnym nie istnieją luki, albowiem zawsze można wywieść normę poprzez analogię z regulacji dotyczącej podobnego zagadnienia (analogia legis) bądź z całości sytemu prawnego (analogia iuris) ${ }^{11}$. Oczywiście jest to element pozytywizmu prawnego poddawany szerokiej krytyce. Przede wszystkim należy zaznaczyć, że wnioskowanie przez analogię uważane jest przez wielu za element twórczej wykładni funkcjonalnej. Jeszcze wyraźniej problem rysuje się przy stosowaniu wykładni teleologicznej oraz historycznej, wykorzystywanych często przez Sądy Najwyższe i Trybunały Konstytucyjne, gdzie obecność elementu twórczego jest oczywista.

Również proces orzekania oparty jest wyłącznie na operacjach logicznych. Mówi się w tym przypadku o tzw. sylogizmie prawniczym, w którym przesłankę większą stanowi generalna i abstrakcyjna norma prawna, zaś przesłankę mniejszą konkretne zdarzenie lub zachowanie objęte regulacją norm czy normy prawnej. Wnioskiem zaś jest konkretne orzeczenie. Za prosty przykład przesłanki większej może posłużyć norma: „kto zabija człowieka, podlega karze x”. Przesłanką mniejszą będzie: „Jan Kowalski dokonał zabójstwa Iksińskiego”. Wnioskiem zaś: „Jan Kowalski zostaje skazany na karę x"12.

11 Analogia jest niedopuszczalna w prawie karnym (nulla poena sine lege). Spójność logiczna sytemu zachowana jest przez skierowaną do sądu zasadę in dubio pro reo. Zgodnie z nią, jeśli sąd na drodze wnioskowań logicznych nie może rozstrzygnąć wątpliwości w sprawie, ma obowiązek rozstrzygnąć je na korzyść oskarżonego. Zob. art. 1 oraz art. $5 \$ 2$ Kodeksu postępowania karnego (tekst jednolity: Dz.U. 2020 poz. 30 z późn. zm.).

12 W rzeczywistości wnioskowania te są daleko bardziej skomplikowane, a formuła orzeczeń jest inna od podanej. 
Stosowanie sylogizmu prawniczego nazywane jest subsumpcją. Polega ona na przyporządkowaniu stanu faktycznego generalnej i abstrakcyjnej normie prawnej w celu wyprowadzenia normy indywidualnej.

Należy nadmienić, że w literaturze przedmiotu wskazuje się, że rozumowania prawnicze nie mieszczą się w zakresie nazwy „wnioskowania logiczne", albowiem ich przesłanką w większości przypadków są wypowiedzi normatywne, które nie są zdaniami w sensie logicznym ${ }^{13}$. Normom bowiem nie przypisuje się wartości logicznej. Nie opisują one rzeczywistości. Jest to stanowisko prawdziwe na gruncie poglądu nonkognitywistycznego, a zatem wskazującego na brak możliwości poznania wartości logicznej norm. Jako wypowiedzi niedeskryptywne można je oceniać wyłącznie w kategoriach słuszny - niesłuszny, skuteczny - nieskuteczny, obowiązujący - nieobowiązujący.

Stanowisko nonkognitywistyczne wydaje się być słusznym, problem ten nie będzie jednak rozważany w dalszej części monografii. Warto jedynie zasygnalizować, że koncepcji pozytywizmu prawnego także można zarzucić tzw. błąd naturalizmu. Powszechnie kojarzony jest on z koncepcjami prawno-naturalnymi, polega na wyprowadzaniu norm prawa natury z faktów naturalnych. Natomiast pozytywistom zarzuca się wyprowadzanie norm prawa stanowionego $\mathrm{z}$ faktów polityczno społecznych. Nie jest to publikacja z zakresu logiki. Spór w powyższej materii nie został rozstrzygnięty.

Założenia pierwotnego pozytywizmu prawnego najlepiej poznać na przykładzie jego twórcy Johna Austina. Należy podkreślić - co często umyka współczesnym badaczom - że Austin nie był przeciwnikiem prawa natury. Uważał jedynie, że przedmiotem jurysprudencji może być jedynie prawo pozytywne ${ }^{14}$. Rozróżniał on prawa ustanowione przez Boga dla ludzi oraz ustanowione przez ludzi dla nich samych. „Całość norm prawnych ustanowionych przez Boga dla człowieka utożsamia $\operatorname{się}^{15} \mathrm{z}$ prawem naturalnym (natural law) albo prawem natury (law of nature). Jedynie o prawie naturalnym można mówić bez użycia metafor i wymieszania pojęć, które winny być wyraźnie rozgraniczone. Ale odrzucając niejednoznaczne wyrażenie prawo naturalne (natural law), nazywam te prawa czy reguły, zbiorczo, prawami boskimi, albo prawami Boga"16. Jak widać, Austin nie tylko nie

13 M. Zirk-Sadowski, Wprowadzenie do filozofii prawa, s. 179.

14 J. Austin, The Province of Jurisprudence Determined, London 1832, s. 1. Skan książki na dzień 17 września 2020 r. znajduje się pod adresem internetowym: https://archive.org/stream/provincejurispr04austgoog\#page/n9/mode/lup

15 W oryginale znajduje się zwrot "frequently styled".

16 J. Austin, The Province..., s. 2. 
odrzucał idei prawa natury, ale utożsamiał je z prawem boskim ${ }^{17}$. Niemniej nie zajmował się nim szerzej.

Twierdził on, że prawo pozytywne jest rodzajem rozkazu o charakterze ogólnym, pochodzącym od suwerena. Jeśli adresat normy nie dostosuje się do owego rozkazu, suweren może zastosować sankcję jako konieczny element prawa, poddany zaś nie może się od niej uchylić18.

Suwerenność Austin rozumie poprzez wskazanie nawyku posłuszeństwa, który powinna posiadać większość członków społeczeństwa. Nawyk ten skłania ich do wypełniania woli suwerena, który może być zarówno jedno-, jak i wieloosobowy. Co interesujące, ów suweren sam nie ma nawyku posłuszeństwa wobec innego podmiotu ${ }^{19}$. Przy czym władza suwerena jest absolutna i nieograniczona.

Uzasadnienie obowiązywania prawa wyprowadza się zatem z pewnego faktu polityczno-społecznego polegającemu na tym, że większość społeczeństwa ulega woli podmiotu tworzącego prawo. Jest to tzw. teza społeczna pozytywizmu, przez niektórych uważana za naczelne twierdzenie tego systemu filozoficznego.

Traktowanie prawa jako rozkazu suwerennej władzy, zabezpieczonej przymusem państwa wywołuje wiele problemów interpretacyjnych. Słusznie na przykład podkreśla się, że trudno traktować w kategoriach rozkazu prawo zobowiązań i znakomitą część pozostałych norm prawa cywilnego. Poza Austinowską definicją znajdzie się też prawo międzynarodowe (według Austina jest to jedynie pozytywna moralność), albowiem nie jest możliwym wyróżnienie w tej gałęzi prawa suwerena ${ }^{20}$.

Wskazać należy, że prawo międzynarodowe w ostatnich dziesięcioleciach ulega przemianom, niemniej sankcja wciąż nie jest uważana za jego część składową. Nie zmienia to faktu, że sankcje usprawiedliwia się często za pomocą argumentów prawno-międzynarodowych. Ponadto, obok umów międzynarodowych, źródłem prawa międzynarodowego jest zwyczaj $\mathrm{w}$ rozumieniu stałej i niezmiennej praktyki w obrocie międzynarodowym.

17 Na marginesie należy stwierdzić, że na gruncie tomizmu utożsamienie prawa natury z prawem boskim jest błędem, albowiem prawo boskie jest prawem bezpośrednio danym człowiekowi przez Boga i reguluje stosunki Bóg-człowiek. Przykładem jest tu 10 przykazań. Na gruncie tomizmu z prawa wiecznego (myśli Boga) wynikają trzy gałęzie praw: prawo naturalne, prawa przyrody oraz prawo boskie. Każde z nich ma swą domenę, i podlega wyłącznie prawu wiecznemu.

18 J. Austin, The Province..., s. 13-15.

19 J. Austin, Lectures on Jurisprudence: Or The Philosophy of Positive Law, London 1885, s. 91-92. Skan książki na dzień 17 września 2020 r. znajduje się pod adresem internetowym: https://archive.org/ stream/lecturesonjuris00campgoog\#page/n8/mode/2up

20 K. Chojnicka, H. Olszewski, Historia doktryn politycznych i prawnych, Poznań 2004, s. 235. 
W ramach Austinowskiej definicji nie mieści się także znakomita część prawa stanowionego przez organizmy, takie jak Unia Europejska (jest to odmienna od prawa międzynarodowego gałąź prawa).

Podkreślić należy, że pierwotny pozytywizm prawny nie był nurtem jednolitym. Na uwagę zasługuje rozwój tej koncepcji w XIX-wiecznej niemieckiej nauce prawa. Kluczowe są tu postacie Rudolfa von Iheringa oraz Georga Jellinka. Pierwszy z nich rozumiał prawo jako normy chroniące interesy tak jednostek, jak społeczeństwa. Naczelnym celem prawa było zapewnienie realizacji tych interesów. Opowiadał się on zatem za prymatem stosowania wykładni teleologicznej. Wzgląd na interes zbliża jego system do utylitarystycznych poglądów Benthama.

Konieczność zapewnienia realizacji przez system prawny interesu prywatnego zmusiła także Iheringa do łączenia elementów pozytywizmu prawnego z elementami socjologii. W myśl poglądów Iheringa prawo tworzy się na drodze konfliktu interesów poszczególnych grup społecznych. Walka ta nigdy nie dobiegnie końca. Norma prawna, by stać się obowiązującą, musi być poparta siłą lub też wypracowany musi być kompromis. Niemniej każda norma prawna napotyka na opór, który musi być przełamany ${ }^{21}$.

Ihering podkreślał, że powszechna zgoda uzyskana na drodze racjonalnej debaty jest naiwnością. Jest to myśl szczególnie istotna w dzisiejszych czasach, w których ponownie pojawiają się nierealne pomysły na osiągnięcie porozumienia na drodze dyskursu czy debaty. Działania podejmowane przez tzw. filozofię dyskursu są z góry skazane na porażkę, albowiem prawo nie jest tworzone na drodze racjonalnej dyskusji, ale na drodze ścierania się interesów.

Podkreślić należy, że Ihering, jako profesor prawa rzymskiego, początkowo nie wykraczał poza ramy pierwotnego pozytywizmu prawnego. Co więcej, opracował on teorię metody formalno-dogmatycznej. W wyniku jednak dalszych przemyśleń, wykroczył on poza sztywne ramy pozytywizmu prawnego, tworząc zarysowaną wyżej filozofię zwaną jurysprudencją pojęććc

Warto mieć na uwadze to, że już w XIX w. sztywne ramy pierwotnego pozytywizmu prawnego zostały przekroczone przez samych przedstawicieli tego nurtu. Wydaje się, że fakt ten umyka wielu komentatorom, którzy zbyt często abstrahują od dokonań filozofii kontynentalnej, zapominając, że pozytywizm prawny miał na kontynencie swych wybitnych przedstawicieli.

21 Por. ibidem, s. 236.

22 Por. H. Izdebski, Historia myśli politycznej i prawnej, Warszawa 2007, s. 252-253. 
Analizując założenia pozytywizmu, nie sposób pominąć dokonań Georga Jellinka. Rozróżniał on trzy cechy charakteryzujące normę prawną i zarazem odróżniające ją od norm moralnych i religijnych. Po pierwsze, norma prawna dotyczy zachowań zewnętrznych człowieka i to tylko wtedy, gdy zachowania te odnoszą się do interakcji z innymi przedstawicielami gatunku. Po drugie, pochodzi od uznanego autorytetu zewnętrznego. Po trzecie, ich obowiązywanie zagwarantowane jest przez zewnętrzną siłę. Jego koncepcja wykracza daleko poza sztywne ramy pozytywizmu Austinowskiego. Przede wszystkim uważał on, że chociaż o konkretnej treści prawa decyduje państwo, to istotny i pierwotny wpływ na jego obowiązywanie ma praktyka społeczna. Prawo zawdzięcza swe obowiązywanie faktom, które są zakorzenione w świadomości ludzi i rozpoznawane jako prawo. Warto zauważyć, że odwołanie się do świadomości prawnej wykracza poza ramy pierwotnego pozytywizmu, w którym nie ma miejsca na psychologizm. Psychologizm doprowadził Jellinka do sformułowania poglądu o normatywnej sile faktów. Mianowicie twierdził on, że prawo wynika z faktów społecznych, poprzez częstotliwość ich występowania ${ }^{23}$. Teza ta może być traktowana jako inspiracja dla Harta, który opracował koncepcję reguły uznania.

Jak wynika z powyższego wywodu, pierwotny pozytywizm prawny nie jest nurtem jednolitym. Rzadko też można odnaleźć wszystkie jego elementy - uznane za kluczowe dla tego nurtu - u jednego autora. Problematyczny jest też wybór filozofów, których twórczość wchodzi w skład przedmiotowego nurtu, np. normatywizm Hansa Kelsena uważany jest często za nurt pozytywizmu twardego. Inni badacze uznają jego teorie czystego prawa za odrębny kierunek, którego nie należy łączyć z pozytywizmem. Z kolei sam Herbert Hart zalicza Kelsena do przedstawicieli tzw. pozytywizmu miękkiego.

Niemniej za rdzeń sposobu myślenia o prawie zwanego pierwotnym (twardym) pozytywizmem prawnym uznaje się następujące tezy:

1. za prawo uważa się normy ustanowione lub uznane przez kompetentny autorytet, przy zastosowaniu odpowiedniej procedury (tzw. teza społeczna);

2. prawo i moralność to odrębne porządki normatywne (przede wszystkim obowiązywanie normy prawa stanowionego nie zależy od jej zgodności z normą moralną; tzw. teza o rozdziale);

3. każdą normę prawa stanowionego można zidentyfikować poprzez wskazanie aktu prawnego, w którym jest opublikowana, a ponadto

23 Por. ibidem, s. 253. 
poprzez wskazanie autorytetu normodawczego, który ja uchwalił bądź uznał (tzw. test pochodzenia);

4. prawa należy bezwzględnie przestrzegać, a zwolnić z tego obowiązku może jedynie inna norma prawna (tzw. pozytywistyczna zasada rządów prawa ${ }^{24}$;

5. prawo jest systemem $\mathrm{w}$ rozumieniu logiki klasycznej, a zatem jest spójne i zupełne, a jego stosowanie sprowadza się do wykorzystywania sylogizmu prawniczego (jako wyłącznie odtwórczych operacji logicznych) $)^{25}$

6. właściwą metodą badania prawa jest metoda analityczna, oraz tzw. teza o nonkognitywizmie, zakładająca, że z twierdzeń o faktach nie można wywodzić norm i odwrotnie ${ }^{26}$.

Test pochodzenia stanowi konsekwencję tezy społecznej, albowiem jeśli za prawo uznajemy normy pochodzące od kompetentnego autorytetu normodawczego, to prawem nie mogą być normy pochodzące $\mathrm{z}$ innego źródła, nawet gdy są to powszechnie akceptowane normy moralne.

W literaturze przedmiotu twierdzi się, że pozytywistyczna wersja rządów prawa stanowi uzupełnienie tezy o rozdziale prawa i moralności. Skoro bowiem prawo obowiązuje niezależnie od norm moralnych, to normy moralne nie mogą zwalniać $\mathrm{z}$ obowiązku przestrzegania prawa ${ }^{27}$.

Punkt 6. powyższego wyliczenia zawiera tezy o charakterze metodologicznym. Są one niemal powszechnie podzielane przez przedstawicieli twardego pozytywizmu prawnego, aczkolwiek problematyczne jest ich zaliczenie do zbioru wyróżników tego nurtu myśli filozoficznej. Poglądy te bowiem charakteryzują większość nurtów filozoficznych obejmujących swym zakresem zagadnienia prawne. W szczególności powszechna jest teza o rozdziale bytu i powinności, obecna już w Kantowskim spojrzeniu na prawo, a w pełni rozwinięta w koncepcji Gustava Radbrucha. Zatem teza o nonkognitywizmie cechuje także szereg koncepcji prawno-naturalnych. Jednym z wyjątków są

24 Rządy prawa (rule of law) pełnią w tradycji anglosaskiej podobną funkcję co konstrukcja państwa prawnego (Rechtsstaat) w tradycji kontynentalnej, mają jednak odmienną genezę. Przez rządy prawa rozumie się zazwyczaj poddanie się prawu stanowionemu przez sądy (nie dowolnie), a jego rodowód wywodzi się wprost z tradycji średniowiecznej. Natomiast państwo prawne jest liberalną odpowiedzią na konstrukcje państwa policyjnego, powszechnego w ustroju monarchii absolutnej, jego rdzeń stanowił postulat sądowej kontroli decyzji administracyjnych, a korzenie tkwią w myśli Kanta, a następnie Roberta von Mohla. Obecnie, także w polskim systemie prawnym, używa się pojęcia „demokratyczne państwo prawne", którego rozwój związany jest z rozwojem konstytucjonalizmu.

25 Poglądu tego nie podzielał na przykład Kelsen, przez niektórych błędnie zaliczany do przedstawicieli pozytywizmu twardego.

26 Por. L. Morawski, Pozytywizm „twardy”..., s. 326.

27 L. Morawski, Główne problemy współczesnej filozofii prawa, Warszawa 2000, s. 16. 
tu koncepcje tomistyczne i neotomistyczne. Także w naukach społecznych niemal powszechnie przyjmuje się pogląd o nonkognitywizmie.

Twierdzenia pozytywizmu twardego zostały zrewidowane i przeformułowane, bądź odrzucone przez kolejne pokolenia pozytywistów prawnych, $\mathrm{w}$ efekcie czego w literaturze przedmiotu powszechnie wyróżnia się tzw. pozytywizm miękki.

\subsection{Podstawy Wyrafinowanego (MięKkiego) POZYTYWIZMU PRAWNEGO}

Za twórcę pozytywizmu wyrafinowanego uważa się Herberta Harta. Dokonał on (poczynając od lat ' $50 \mathrm{XX}$ w.) aktualizacji oraz przeformułowania Austinowskiej koncepcji prawa, która stała się anachroniczna. W szczególności nie uwzględniała języka jako zjawiska pośredniczącego pomiędzy suwerenem a adresatami normy prawnej.

Austinowska teoria prawa nie bierze pod rozwage podstawowych wyników badań fenomenologii, a mianowicie wyróżnienia „znaczenia”28 od psychiki człowieka. Źródłem tego poglądu jest wniosek z badań fenomenologicznych - teza o intencjonalnym charakterze aktów świadomości (stałego nakierowania świadomości na obiekt). W wyniku tego przyjęto, że „znaczenie” stanowi intencjonalny obiekt świadomości. Co ważne, owo „znaczenie” winno być badane za pomocą analiz językowych, bowiem „znaczenie” (jako nakierowanie świadomości na coś, co nie jest nią samą) pojawia się w języku, zaś człowiek zawsze myśli za pomocą jakiegoś języka. Stąd wniosek, że świat jawi się poprzez język. Świat zatem poznać możemy za pomocą analizy samego języka, a mówiąc precyzyjniej - za pomocą znaczeń w tym języku zawartych ${ }^{29}$.

Filozofia języka nie jest tematem niniejszej publikacji. Z uwagi jednak na to, że pozytywizm prawny miękki stworzony został w wyniku rozwoju tej dziedziny filozofii, konieczne jest przedstawienie najbardziej istotnych z tego punktu widzenia tez tzw. „Zwrotu językowego” dokonanego na

28 „Znaczenie” rozumie się tu jako nakierowanie świadomości ukierunkowanej na rozumienie „znaku” poza nią samą. Tak rozumiane „znaczenie” staje się wyodrębnionym przedmiotem nieutożsamionym ze zjawiskiem psychicznym, co uczyniło je przedmiotem analiz lingwistycznych. W konsekwencji twierdzono, że świat jawi się poprzez „znaczenia”.

29 Por. M. Zirk-Sadowski, Wprowadzenie do filozofii prawa, s. 95. 
przełomie XIX i XX w., a najpełniej wyrażonego przez neopozytywistów zgromadzonych w Kole Wiedeńskim.

Rdzeniem owego zwrotu są dwie wspomniane wcześniej tezy: (1) pogląd, że człowiek postrzega świat za pomocą języka oraz (2) związana z nim teza o braku możliwości odróżnienia wypowiedzi językowych od treści świadomości. Prowadzi to do fundamentalnego wniosku, zgodnie z którym nie tylko poznajemy świat poprzez język, ale także używając określonego języka, narzucamy sobie formy poznania świata. Teza ta ma kluczowe znaczenie dla współczesnej filozofii języka. $\mathrm{Na}$ jej podstawie stworzona została później koncepcja tzw. wypowiedzi performatywnych, stanowiących zarówno jeden z kluczowych elementów współczesnej filozofii języka, jak i nieodłączny element wyrafinowanego pozytywizmu prawnego.

Skutkiem wspomnianego zwrotu językowego było całkowite odrzucenie przez neopozytywistów z Koła Wiedeńskiego możliwości badania wszelkich wypowiedzi o charakterze nie tylko metafizycznym, ale i aksjologicznym czy epistemologicznym, jako pozbawionych sensu. Sens posiadały jedynie wypowiedzi, którym można nadać wartość prawdy bądź fałszu. Prawdę rozumieli oni na sposób klasyczny - jako zgodność sądu z rzeczywistością. Przy czym prawdziwe bądź fałszywe mogło być jedynie zdanie opisowe, nie zaś normatywne. Za pomocą tych ostatnich nie opisujemy bowiem rzeczywistości, ale wartościujemy bądź postulujemy jakiś stan rzeczy. Ich antykognitywizm przybrał skrajną formę. Postulowali oni „oczyszczenie” filozofii z wszelkich wypowiedzi oceniających czy normujących. Zgodnie z tym poglądem, poza granicami filozofii znajdować miała się zarówno aksjologia, jak i filozofia prawa. Postulowali oni stworzenie filozofii jako nauki opartej na zdaniach protokolarnych. Zdania te miały być sprawozdaniami z czystego doświadczenia, co stanowiło najsłabszy i skutecznie podważany element tej teorii ${ }^{30}$. Nie istnieje bowiem doświadczenie oderwane od teorii. Każdy sąd zawiera w sobie pojęcia teoretyczne, a zatem stworzenie zdań protokolarnych jest postulatem niemożliwym do spełnienia. Innymi słowy, nie istnieje czyste doświadczenie. Tezę tę autor niniejszego tekstu wywodzi z rozważań Kanta ${ }^{31}$. Niemniej odwołanie do teorii epistemologicznej nie jest w tym przypadku konieczne, ponieważ teza o braku możliwości czystej obserwacji (lub jej nieprzydatności) jest powszechnie przyjmowana przez przedstawicieli nauk szczegółowych. Wskazuje się na przykład na „konstrukty teoretyczne” jako

30 Por. ibidem, s. 96-97.

31 I. Kant, Krytyka czystego rozumu. Tom 1, Warszawa 1957, s. 78, B17. 
byty idealne, a zatem nie mające odpowiedników w świecie empirycznym (np.: inteligencja, osobowość itp. ${ }^{32}$. Na marginesie warto również wskazać, że ignorancją byłoby określanie współczesnych badań prowadzonych na gruncie fizyki czy innych nauk przyrodniczych jako czystej obserwacji ${ }^{33}$.

Warto w tym miejscu zauważyć, że utożsamienie języka z treścią świadomości budzi uzasadnione wątpliwości. Przede wszystkim nikt w dziejach żadnej z uprawianych przez człowieka dziedzin wiedzy nie podał chociażby zbliżonej do satysfakcjonującej definicji świadomości. Formułowanie zatem kategorycznych wniosków o związkach świadomości z językiem pozbawione jest podstaw. Także język rozumiany jest rozmaicie. Najbardziej trafna - ze względu na jej zakres, treść oraz precyzję - jest definicja zaczerpnięta z psychologii, traktująca język jako „system kodowania znaczeń poprzez wykorzystanie skończonego zbioru symboli”34.

Rozważając tezę o koniecznym związku wypowiedzi językowych i treści świadomości, warto odnieść się w tym zakresie do aktualnego stanu wiedzy $\mathrm{w}$ dziedzinie psychologii, albowiem to $\mathrm{z}$ jej dokonań niejednokrotnie w tym przedmiocie korzysta filozofia.

Psychologia zajmuje się m.in. badaniem związków między mową (termin węższy od języka) i myśleniem (na potrzeby niniejszego tekstu utożsamia się myślenie ze świadomością, jest to jednak uproszczenie, samo myślenie to jeden $\mathrm{z}$ wielu procesów poznawczych, które zostały tu pominięte).

Problem sprowadza się do pytania, czy język determinuje myślenie, czy też procesy myślenia są od języka niezależne. Pierwszy z poglądów określa się jako hipotezę determinizmu językowego lub hipotezę Sapira-Whorfa. Zakłada ona, że język decyduje o przetwarzaniu informacji, postrzeganiu rzeczywistości, wykorzystywaniu zasobów pamięciowych oraz, co ważne, o sposobie formułowania sądów ${ }^{35}$.

Obecnie odrzuca się mocną wersję hipotezy determinizmu językowego, przyjmując, że nie ma dowodów empirycznych na twierdzenie, iż wszelkie myślenie zawsze determinowane jest przez język. W szczególności podważa się zasadność wielu badań, na które wciąż powołują się niektórzy przedsta-

32 P. Francuz, R. Mackiewicz, Liczby nie wiedza, skąd pochodzą. Przewodnik po metodologii i statystyce nie tylko dla psychologów, Lublin 2007, s. 18.

33 Przykładem może być Wielki Zderzacz Hadronów (LHC). Prosty zapis danych z pracy tego urządzenia zapełniłby w ciągu kilkudziesięciu godzin pracy pamięć wszystkich komputerów świata. Innymi słowy, byłoby to urządzenie całkowicie bezużyteczne. Aby pracowało ono zgodnie z jego celem, konieczna jest teoria dokonująca selekcji zapisywanych danych (na marginesie należy dodać, że nawet prosty zapis danych zawiera w sobie teorię).

34 E. Nęcka, J. Orzechowski, B. Szymura, Psychologia poznawcza, Warszawa 2007, s. 590.

35 Por. ibidem, s. 599. 
wiciele innych nauk. Na przykład argument jakoby Eskimosi dysponowali kilkunastoma różnymi określeniami śniegu, ale nie znali pojęcia nadrzędnego, wynika, jak się okazało, ze słabej znajomości ich języka ${ }^{36}$. Wskazuje się, że mają oni około 12 słów mogących opisać śnieg. Nie jest to liczba znacząco odbiegająca od słów używanych innych językach, jeśli uwzględni się wyrażenia typu: „zamieć”, czy „zawieja”"

Nie zmienia to faktu, że w wielu językach istnieją pojęcia, których nie sposób przełożyć na inne, co różnicuje sposób postrzegania otoczenia w odniesieniu do użytkowników odmiennych języków, a zatem ma determinować sposób poznania. Często przytacza się także badania z zakresu percepcji barw, wskazujące, że ludzie z różnych kultur inaczej nazywają kolory oraz inaczej sytuują granice między kolorami. Części z tych badań zarzuca się błędy metodologiczne, jednak najnowsze analizy potwierdzają hipotezę determinacji językowej w odniesieniu do percepcji kolorów ${ }^{38}$.

Za hipotezą tą przemawia także fakt, że pacjenci $\mathrm{z}$ afazją, polegającą na utracie nazw kolorów, mają w znacznym stopniu zaburzoną zdolność ich postrzegania. Powyższą hipotezę potwierdza też skuteczność manipulacji językowych. Dobór słów wpływa bowiem na postrzeganie opisanego przez nie zjawiska. Inaczej ludzie odnoszą się do zaleceń politycznej poprawności, inaczej zaś do cenzury, choć słowa te opisują to samo zjawisko ${ }^{39}$.

Istnieją również argumenty podważające zasadność tezy o determinacji. Wskazuje się na przykład na istnienie wad rozwojowych powodujących niepełnosprawność intelektualną, które nie zawsze wiążą się z upośledzeniem funkcji językowych ${ }^{40}$. Opisany jest na przykład przypadek sawanta ${ }^{41}$, który posługiwał się biegle 16 językami (tłumaczył z zachowaniem form gramatycznych) - przy upośledzeniu wszystkich innych funkcji intelektualnych ${ }^{42}$. Krytyka tezy o determinacji językowej płynie również z koncepcji tzw. języka myśli Fodora, który jest niezależny od języka etnicznego oraz z koncepcji wrodzonej kompetencji językowej (gramatyki generatywnej) Chomsky’ego ${ }^{43}$.

36 Ibidem, s. 602.

37 P. Francuz, R. Mackiewicz, Liczby nie wiedza..., s. 18.

38 E. Nęcka, J. Orzechowski, B. Szymura, Psychologia poznawcza, s. 600.

39 Ibidem, s. 601.

40 Ibidem, s. 602.

41 Człowiek niepełnosprawny intelektualnie o wybitnych uzdolnieniach w wąskim wycinku rzeczywistości, na przykład posiadający niezwykle wydajną pamięć przy braku zdolności do samodzielnego funkcjonowania w społeczeństwie.

42 I. Kurcz, Psychologia języka i komunikacji, Warszawa 2005, s. 182-183.

43 Ibidem, s. 186. 
Na gruncie aktualnych badań psychologicznych zasadną wydaje się być teza, że język w ogromnym stopniu kształtuje ludzkie poznanie, lecz nie determinuje go w sposób absolutny. Mówiąc ściślej, „język i myślenie są niezależne od siebie, ale wzajemnie na siebie wpływają" ${ }^{\text {"4 }}$. Istnieje zatem poznanie oderwane od języka, co obala stanowisko przedstawicieli Koła Wiedeńskiego.

Kolejnym etapem zwrotu językowego, którego nie sposób pominąć, była twórczość tzw. „wczesnego Wittgensteina” (okres Traktatu logiczno-filozoficznego). Była to nieudana próba odnalezienia wspólnej formy języka i świata przy pomocy narzędzi logiki formalnej, albowiem logika ta, zdaniem Wittgensteina, stanowiła najgłębszą strukturę języka ${ }^{45}$. Innymi słowy, poszukiwano logicznej struktury zawartej w języku, co miało umożliwić poznanie świata.

Z punktu widzenia filozofii prawa istotnym jest wniosek z powyższego wywodu. Wittgenstein, uznając istnienie logicznej formy wspólnej dla świata i języka, musiał przyznać, że czym innym jest sensowność zdania rozumiana jako jego poprawność z punktu widzenia logicznej składni, a czym innym jego prawdziwość ${ }^{46}$. Doprowadziło to do stworzenia tzw. „modeli logicznych”, a zatem zdań poprawnych logicznie (sensownych), odnoszących się do światów możliwych, nie zaś do świata realnego. Na tej podstawie podjęto nieudaną próbę przezwyciężenia nonkognitywizmu poprzez stworzenie rachunku zdań zbudowanego z tzw. wypowiedzi deontycznych, czyli wypowiedzi, które same nie będąc normami, relacjonują ich treść lub stwierdzają ich obowiązywanie (mówiąc ściślej, określają dany czyn jako nakazany, zakazany, dozwolony, fakultatywny albo indyferentny z punktu widzenia obowiązującego sytemu prawnego). Zdania te nie są zatem powinnościami, lecz relacją z powinności. Można więc przypisać im wartość logiczną. Przykładem może być zamiana zdania będącego normą, „kto zabiera w celu przywłaszczenia cudzą rzecz

44 Ibidem, s. 178.

45 W tym sensie, że do poznania prawdziwości zdania wystarczające jest posłużenie się symbolami - nie jest potrzebne odwołanie się do rzeczywistości. Z tego faktu wywodzi Wittgenstein równoprawną pozycję wszystkich praw logicznych (każde da się sprowadzić do tautologii).

46 Wittgenstein rozróżnia sensowne zdania oznajmujące oraz prawdziwe zdania oznajmujące. Pierwsze są prezentacją stanu rzeczy, drugie - faktu. Przy czym stan rzeczy jest jedynie możliwym powiązaniem przedmiotów, zaś fakt jest prawdziwym powiązaniem przedmiotów. Warto zaznaczyć, że dla Wittgensteina przedmioty dają się pomyśleć tylko w relacji do innych przedmiotów. W swych dziennikach przytacza on przykład rozróżnienia pręta od kuli. Pręt - w odróżnieniu od kuli - można oprzeć o ścianę. Możliwość oparcia o ścianę jest częścią istoty pręta. O istocie decydują zatem możliwości występowania w określonych stanach. Takie możliwości nazwał Wittgenstein wewnętrznymi właściwościami przedmiotu, a ich zbiór całkowity - formą przedmiotu. Właściwości zewnętrzne to według niego faktyczne powiązania z innymi przedmiotami. Zob. E. Coreth, P. Ehlen, G. Haeffner, F. Ricken, Filozofia XX wieku, Kęty 2004, s. 153. 
ruchomą, podlega karze x” na zdanie stanowiące relację z tej normy: „w polskim systemie prawnym obowiązuje norma mówiąca, że ten, kto dokonuje zaboru w celu przywłaszczenia cudzej rzeczy ruchomej, podlega karze x". Przy czym, jak zostało wskazane, na gruncie nonkognitywizmu wartość logiczną przypisać można tylko zdaniu drugiemu ${ }^{47}$.

Wskazać jednak należy, że logika deontyczna ma w zakresie tak rozumowań prawniczych, jak i innych, ograniczony zakres stosowania. Stosowanie jej rodzi szereg paradoksów, które powodują konieczność komplikacji zasad rachunku zdań, a te z kolei prowadzą do kolejnych paradoksów, co rodzi ponowną potrzebę rozbudowy teorii itd.

Nie zagłębiając się w szczegóły, wskazać należy, że logika deontologiczna jest jednym z systemów logiki norm. Zdaniem profesora Ziembińskiego, „nie zbudowano dotąd takiego systemu logiki norm, który byłby tak powszechnie przyjęty, jak rachunek zdań w logice formalnej. Sprawa zbudowania logiki norm jest nadzwyczaj zawiła, trudna i dyskusyjna"48.

Ponadto koncepcja wczesnego Wittgensteina niezgodna jest z oczywistą obserwacją - nie sposób wskazać jednego języka, który miałby posiadać wspólną ze światem formę. Język bowiem jest wytworem kultury, a zatem jest zmienny w czasie i różnorodny. Istnieje wiele systemów kodowania znaczeń (wiele języków). Systemy te są wzajemnie powiązane oraz zależne od sposobu ich użytkowania i kontekstu tego użycia. Mówiąc języka Wittgensteina, można powiedzieć, że znaczenia funkcjonują w swoistej scenerii gier językowych ${ }^{49}$. Co więcej, znaczenia słów nie sposób „uchwycić od ra$\mathrm{zu}^{\text {"50 }}$, jawią się one jedynie w wyniku uczestnictwa w danej grze językowej.

Prowadzi to do kluczowego dla filozofii prawa wniosku: treść i zakres pojęć prawnych zależna jest od kontekstu ich użycia. Innymi słowy, zachowania użytkowników języka wpływają na rozumienie pojęć definiowanych przez ustawodawcę czy obecnych w praktyce orzeczniczej. Teza ta stanowiła punkt wyjścia dla filozoficznych dociekań Herberta Harta ${ }^{51}$.

W filozofii tzw. późnego Wittgensteina John Langshaw Austin dostrzegł kluczową dla późniejszych wywodów Harta performatywną funkcję języka. Zauważył, że język nie zawsze jedynie opisuje rzeczywistość. Często ją również tworzy. Takie wypowiedzi Austin nazywa performatywnymi, wskazując, że ich wygłoszenie ,jest wykonaniem jakiejś czynności, jest czymś, o czym

47 M. Zirk-Sadowski, Wprowadzenie do filozofii prawa, s. 98-99.

48 Z. Ziembiński, Logika praktyczna, Warszawa 2002, s. 247.

49 L. Wittgenstein, Dociekania filozoficzne, Warszawa 1972, § 179.

50 Ibidem, $\$ 191$

51 Por. M. Zirk-Sadowski, Wprowadzenie do filozofii prawa, s. 101. 
nie myśli się normalnie jako tylko o powiedzeniu czegoś”52. Innymi słowy, wypowiedź taka „nie mówi czegoś, lub nie wyłącznie mówi, lecz coś robi”"53.

Istotnym jest, że wypowiedzi performatywnej nie można przypisać wartości logicznej. Może być ona oceniana jedynie w kategoriach „udana nieudana”, nie zaś „prawdziwa - fałszywa” ${ }^{4}$. Wskazuje to na niemożliwość ujęcia rzeczywistości prawnej wyłącznie za pomocą zdań opisowych, znanych logice klasycznej.

Na marginesie wskazać należy, że John Langshaw Austin wprowadził rozróżnienie na czynności lokucyjne, illokucyjne oraz perlokucyjne. Wszystkie one polegają na działaniu, różni je natomiast sposób ingerencji w zastaną rzeczywistość. Czynność lokucyjna polega na wypowiedzeniu zdania z pewnym sensem i odniesieniem. Illokucyjna polega na wypowiadaniu zdań mających moc konwencjonalną i na jej podstawie wywołujących zmianę w rzeczywistości użytkowników języka, np.: przyrzekanie, ostrzeganie, rozkazywanie. Zaś czynność perlokucyjna jest tym, co osiągamy za pomocą wypowiadania zdań, np.: perswadowanie, powstrzymywanie czy wprowadzanie w błąd $\mathrm{d}^{55}$.

W literaturze przedmiotu wskazuje się, że opisany wyżej rozwój filozofii języka spowodował konieczność nowego sposobu postrzegania prawa. Prawo stanowione nie mogło być już jedynie materiałem analizy logicznej. Konieczne stało się zbadanie jego fenomenu z perspektywy użytkownika i podmiotu aktywnie uczestniczącego w grze językowej. Przede wszystkim zaś należało uwzględnić język jako element pośredniczący pomiędzy twórcą prawa a odbiorcą prawa oraz uwzględnić fakt, że uczestnicząc w owej grze, stajemy się jednocześnie jej współtwórcami, co doprowadziło do odejścia od Austinowskiego pojęcia suwerena jako niezależnego prawodawcy ${ }^{56}$. Zdaniem Harta należało uwzględnić wewnętrzny, krytyczno-refleksyjny punkt widzenia ${ }^{57}$.

Biorąc pod uwagę powyższy wywód, wskazać należy, że wyrafinowany pozytywizm prawny cechuje $\operatorname{sie}^{58}$ :

1. brakiem możliwości poznania prawa w sposób bezpośredni, jako rozkazu suwerena (pośrednikiem jest język);

2. odejściem od koncepcji suwerena jako niezależnego prawodawcy;

52 J. L. Austin, Mówienie i poznawanie: Rozprawy i wykłady filozoficzne, Warszawa 1993, s. 555.

53 Ibidem, s. 573.

54 Zob. ibidem.

55 Ibidem, s. 654-655.

56 Por. M. Zirk-Sadowski, Wprowadzenie do filozofii prawa, s. 183-185.

57 H. L. A. Hart, Pojęcie prawa, Warszawa 1998, s. 128.

58 Por. M. Zirk-Sadowski, Wprowadzenie do filozofii prawa, s. 183-195; L. Morawski, Pozytywizm "twardy"..., s. 343. 
3. wprowadzeniem nowej perspektywy: uczestnika gry językowej;

4. wskazaniem na tzw. otwartą kontekstowość prawa, wynikającą z niemożliwości przewidzenia przez ustawodawcę złożoności przyszłych kontekstów stosowania normy, co skutkuje nadaniem sędziemu władzy dyskrecjonalnej, a zatem poszerzeniu jego roli poza podmiot posługujący się wyłącznie sylogizmem prawniczym;

5. możliwością oceny moralnej obowiązującego prawa, bez wpływu jednak na jego obowiązywanie;

6. wprowadzeniem minimalnej treści prawa natury, rozumianej jako reguły zapewniającej przetrwanie. 



\section{Wybrane zagadnienia polskiego systemu prawnego jako ilustracja filozofii prawa Herberta Harta}

Wybór zagadnień dokonany został z uwagi na specyfikę filozofii Herberta Harta. Opisuje on zjawiska prawne jako fakty empiryczne. Opis ten jednak powstał na gruncie sytemu Common Law. Należy zatem odpowiedzieć na pytanie, na ile uprawnione jest odnoszenie wniosków wywodzonych $\mathrm{z}$ analiz Harta do polskiego sytemu prawnego. W tym celu w podrozdziale 2.1 przedstawione zostanie podobieństwo między systemem Common Law a systemami prawa kontynentalnego poprzez ukazanie wspólnego korzenia, $\mathrm{z}$ jakiego się wywodzą.

Filozofia Harta może być postrzegana jako filozofia języka. Kluczowe jest zatem zrozumienie, czym jest język prawa nie tylko na gruncie brytyjskim, ale i na polskim. W szczególności przybliżenia wymaga relacja języka prawnego i prawniczego. Bez jej zrozumienia jakakolwiek refleksja filozoficzno-prawna pozbawiona jest sensu, stąd podrozdział 2.2 opisuje naturę języka prawnego.

Przedmiotem podrozdziału 2.3 jest - kluczowa dla zrozumienia myśli Harta - koncepcja otwartości języka prawnego. Dla wykazania aktualności i trafności jego wywodu konieczny jest, chociaż skrótowy, opis form tej 
otwartości na gruncie polskiego prawa. Pozwoli to na zbadanie czy i na ile Hartowskie rozumienie prawa odbiega od współczesnego systemu polskiego prawa.

Informacje zawarte $\mathrm{w}$ niniejszym rozdziale zestawione zostaną z tezami przedstawionymi w rozdziale 3 . oraz posłużą do sformułowania wniosków zawartych w Podsumowaniu.

\subsection{WSPÓLNA GENEZA EUROPEJSKICH KULTUR PRAWNYCH}

Pozytywizm prawny powstał na specyficznym gruncie anglosaskiej kultury prawnej, która cechuje się odrębnym od kontynentalnego systemem prawnym: Common Law, ukształtowanym - najprościej mówiąc - na drodze orzeczeń sądów królewskich'. Cechą charakterystyczną tego systemu jest odmienny od kontynentalnego schemat myślenia.

W pierwszym rzędzie należy odpowiedzieć na pytanie, czy różnice kulturowe istniejące między kontynentalnymi systemami prawnymi a Common Law nie są na tyle duże, że namysł nad poglądami Herberta Harta pozostać musi bez związku z rozważaniami nad polskim systemem prawa.

W literaturze przedmiotu podkreśla się, że systemy prawa kontynentalnego oparte są na dedukcyjnym sposobie rozumowania, wywodzącym się od Arystotelesa. Polega on na wywodzeniu ze zdań aksjomatycznych rozstrzygnięć natury szczegółowej, na drodze dedukcji. Jest to zatem klasyczny przykład stosowania sylogizmu prawniczego w rozumieniu twardego pozytywizmu prawniczego. Anglosaską kulturę prawną cechuje natomiast wywodzący się od Cycerona tzw. topiczny sposób myślenia, polegający na poszukiwaniu rozwiązania nie na drodze dedukcji, ale w samym kazusie. Z owego kazusu wywodzi się przesłanki, na podstawie których tworzy się następnie pojęcia, normy i reguły prawne. Jest to zatem sposób myślenia oparty nie na dedukcji, lecz na dialektyce ${ }^{2}$. W literaturze przedmiotu podkreśla się, że w prawie rzymskim przez wieki funkcjonował swoisty dualizm prawny i obecne były oba sposoby myślenia (w szczególności wskazać trzeba

1 K. Sójka-Zielińska, Historia prawa, Warszawa 2005, s. 76.

2 H. Izdebski, Elementy teorii i filozofii prawa, Warszawa 2008, s. 87-88.

Mariusz Leleno-Czarnak - Aktualnośc filozofil prawa Herberta Harta jako krytyki pierwotnego pozytywizmu prawnego... 
na konsekwencje wyodrębnienia, obok procesu legisakcyjnego, procesu formułkowego ${ }^{3}$ ). Omawianie tego zagadnienia nie mieści się jednak w ramach niniejszego tekstu.

$\mathrm{Z}$ tego punktu widzenia system Common Law jest z natury rzeczy bliższy wyrafinowanemu pozytywizmowi prawniczemu niż systemy kontynentalne. Wskazuje to również, że proste odniesienie rozstrzygnięć anglosaskiej filozofii prawa do warunków Polski może rodzić zastrzeżenia. Porównania są jednak jak najbardziej możliwe i wskazane. Zarówno bowiem Common Law, jak i systemy bliższe nam kulturowo mają wspólne źródło w postaci prawa rzymskiego.

Podkreślenia wymaga to, że prawo rzymskie ukształtowało zarówno systemy kontynentalne, jak i anglosaski sposób pojmowania prawa ${ }^{4}$. Niemniej wskazuje się, że recepcja prawa rzymskiego na Wyspach Brytyjskich przebiegała w sposób odmienny i mniej inwazyjny niż na kontynencie. Przede wszystkim prawnicy angielscy w XII i XIII w. przejęli z prawa rzymskiego elementy metody i część zasad ogólnych. Odrzucili natomiast niemal całkowicie partykularne rozwiązania i instytucje. Wskazać również należy, że głębsze czerpanie z rzymskiej kultury prawnej nastąpiło w Anglii wraz z próbami wzmocnienia władzy monarszej ${ }^{5}$.

Ponadto zauważyć trzeba, że prawotwórcza rola precedensu jako źródła prawa ma również rzymski rodowód. Korzeni należy szukać już w edyktach pretorskich, a następnie $\mathrm{w}$ ius respondendi $\mathrm{z}$ okresu pryncypatu, a zatem prawa nadanego wybitnym jurystom rzymskim udzielania odpowiedzi ex auctoritate princips. Przy czym opinie te wiązały sądy. Początkowo w konkretnej sprawie, a z biegiem lat, na mocy zwyczaju, uzyskały moc ogólnie obowiązującego prawa ${ }^{6}$.

Nie ulega natomiast najmniejszej wątpliwości, że prawo kontynentalne, $\mathrm{w}$ tym również polskie, jest zakorzenione w prawie rzymskim w tak ogromnym stopniu, że obudowanie tego oczywistego faktu przypisami z literatury fachowej pozbawione jest jakiegokolwiek praktycznego znaczenia. Wskazać jedynie należy, że zarówno sposób argumentacji, jak i pojęcia oraz instytucje i partykularne rozwiązania polskiego systemu prawnego (oraz innych Europy kontynentalnej) wywodzą się z rozwiązań rzymskich. Za ilustrację może posłużyć porównanie zachowanego podręcznika do prawa z czasów

\footnotetext{
3 Zob. W. Wołodkiewicz, M. Zabłocka, Prawo rzymskie. Instytucje, Warszawa 2001, s. 292.

4 Ibidem, s. 85.

5 K. Sójka-Zielińska, Historia prawa, s. 75.

6 Por. M. Sczaniecki, Powszechna historia państwa i prawa, Warszawa 2003, s. 41-42.
} 
rzymskich, a dokładnie komentarza II i III Instytucji Gaiusa ${ }^{7}$, z chociażby księgą drugą (Własność i inne prawa rzeczowe) i czwartą (Spadki), obowiązującego Kodeksu cywilnego ${ }^{8}$.

Nie ulega zatem wątpliwości, że polski język prawny (oraz prawniczy) oparty jest na osiągnięciach prawa rzymskiego. Wywodzi się z niego nie tylko system pojęciowy, ale - co ważniejsze - specyficzny sposób myślenia. Prawo rzymskie jawi się obok greckiej filozofii i chrześcijaństwa jako jeden z trzech filarów kultury europejskiej. Również tak, jak dwa pozostałe filary, taktować je należy ${ }^{9}$ jako źródło tzw. przed-rozumień w znaczeniu nadanemu temu słowu przez hermeneutykę. Nie sposób zatem zrozumieć świata w oderwaniu od owych trzech elementów.

\subsection{JEZZYK PRAWNY A PRAWNICZY}

W kontekście pozytywizmu prawnego należy zwrócić uwagę na problem określenia stosunku języka prawnego i prawniczego do języka etnicznego. Język prawny to język teksów prawnych. Język prawniczy natomiast jest językiem organów stosujących prawo (na przykład wyroki sądów) oraz językiem doktryny (na przykład podręczniki prawnicze) ${ }^{10}$.

Nie ulega wątpliwości, że język prawniczy jest metajęzykiem w stosunku do języka prawnego. Problemy rodziło jednak określenie języka prawnego. Warto zauważyć, że określenie języka prawnego jako języka drugiego stopnia (metajęzyka) w stosunku do języka etnicznego stanowi niezbędny wymóg

7 Gaius, Instytucje, Poznań 2003, s. 41-149.

8 Tekst jednolity: Dz.U. 2019 poz. 1145 z późn. zm.

9 Jest to pogląd autora niniejszego tekstu podzielany przez znaczną część środowiska prawniczego, oparty głównie na poglądach historycznej szkoły prawa, która wyróżniła tzw. prawo prawnicze Juritenrecht jako metodę rozumienia (lub odkrywania) prawa, traktowanego jako wytwór historii. Źródłem rozumienia było, obok niemieckiego prawa zwyczajowego, prawo rzymskie oraz - co ważniejsze - przekazywane od pokoleń metody ich interpretacji. Analogiczna idea - ale na szerszym gruncie - propagowana jest na przykład przez Gadamera, który twierdzi, że ludzkie poznanie jest skończone i zakorzenione w kulturze (Gadamer wywodzi swe wnioski z innych niż historyczna szkoła prawa źródeł. Opiera się na tezie Heideggera, wskazującej, że bycie jest zawsze byciem czegoś, a co za tym idzie - poszukiwanie sensu przybiera postać koła hermeneutycznego). Za prawdziwy należy uznać pogląd wskazujący, że poznanie zakorzenione jest w kulturze, a myślenie prawnicze jest istotnym elementem tej kultury, ewolucyjnie rozwijanym co najmniej od czasów rzymskich.

10 Por. S. Lewandowski, H. Machińska, A. Malinowski, J. Petzel, Logika dla prawników, Warszawa 2003 , s. $24-25$. 
pierwotnego pozytywizmu prawnego ${ }^{11}$. Język aktów prawnych miał bowiem być zamkniętym i zupełnym systemem, z którego, wyłącznie na drodze rachunku zdań, sędzia miał wyprowadzać konkretna normę.

Uznanie zaś języka prawnego za część składową języka etnicznego odpowiada postulatowi otwartej kontekstowości prawa (możliwość uwzględnienia kontekstu w procesie ustalania treści normy prawnej w danym stanie faktycznym), będącego podstawą wyrafinowanego pozytywizmu prawnego. Przy takim rozumieniu język prawny nie jest zamkniętym systemem, ale funkcjonuje w relacji do znaczeń obecnych w języku etnicznym. Chcąc zmodyfikować znaczenie słów języka etnicznego, ustawodawca tworzy definicje legalne. Jeśli jednak dany termin nie jest zdefiniowany w tekście prawnym, definicji poszukuje się w słowniku języka polskiego.

Za przykład otwartości języka prawnego niech posłuży przestępstwo zniewagi określone w typie podstawowym w art. $216 \$ 1$ Kodeksu karnego ${ }^{12}$ : „Kto znieważa inną osobę w jej obecności albo choćby pod jej nieobecność, lecz publicznie lub w zamiarze, aby zniewaga do osoby tej dotarła, podlega grzywnie albo karze ograniczenia wolności”.

Jak widać ustawodawca nie wprowadza legalnej definicji zniewagi. Nie jest bowiem możliwe uprzednie uwzględnienie wszelkich kontekstów, w jakich używane będą słowa. Otwartość kontekstualna języka jest wymuszona naturą stosunków społecznych. Doskonale obrazuje to postanowienie Sądu Najwyższego z dnia 7 maja 2008 r. o sygn. III KK 234/07'13: „Przestępstwo zniewagi polega na użyciu słów obelżywych lub sformułowanie zarzutów obelżywych lub ośmieszających, postawionych w formie niezracjonalizowanej”. O uznaniu określonych sformułowań za „znieważające” decydują w pierwszym rzędzie ogólnie przyjęte normy obyczajowe. Określeniem znieważającym nie może być bowiem słowo „erotoman”, oznaczające w języku potocznym „człowieka o chorobliwie wzmożonej pobudliwości płciowej lub o nienormalnie spotęgowanym zainteresowaniu dziedziną stosunków płciowych".

Jak wynika z powyższego cytatu, sąd w toku orzekania zmuszony jest do odwołania się do słownikowej (etnicznej) definicji „erotomana”. Ponadto obowiązany jest odnieść ową definicję do powszechnie przyjętych norm obyczajowych.

11 Jeśli prawo ma być stosowane wyłącznie za pomocą prostej subsumpcji, a znaczenia terminów prawniczych ustalane wyłącznie na drodze operacji logicznych, język prawny nie może być rozumiany jako rejestr języka naturalnego (język I stopnia). Ten ostatni bowiem cechuje potencjalna nieostrość.

12 Tekst jednolity: Dz.U. 2020 poz. 1444.

13 OSNKW 2008/9/69. 
Powyższy przykład ukazuje, że polski system prawny w żadnym razie nie odpowiada koncepcji języka prawnego proponowanej przez pierwotny pozytywizm prawny. Odpowiada jednak uwzględnionym przez wyrafinowany pozytywizm prawny wymogom gier językowych.

Podobnych do powyższego przykładów orzecznictwa są tysiące i nie ma potrzemy ich w niniejszym tekście przedstawiać. Odnosząc się jednak do przykładu nazwania kogoś erotomanem, należy dla porządku stwierdzić, że w określonym kontekście taki czyn może wypełnić znamiona przestępstwa zniesławienia (pomówienia) z art. $212 \$ 1$ Kodeksu karnego (nie zaś zniewagi) ${ }^{14}$.

W literaturze przedmiotu podkreśla się, że ,język prawny jest językiem I stopnia”15, nie zaś językiem II stopnia, jak wynikałoby z założeń pierwotnego pozytywizmu prawnego.

Jako ciekawostkę wskazać można fakt, że ten oczywisty dziś pogląd, w polskiej nauce prawa ugruntował się stosunkowo późno. Do lat ' $80 \mathrm{XX}$ w. przeważało bowiem - pod wpływem szkoły lwowsko-warszawskiej - stanowisko przeciwne, traktujące język prawny jako względnie samodzielny przedmiot badań, przy jednoczesnym oddzieleniu problemów społecznych od zagadnień językowych ${ }^{16}$. Aktualnie powszechnie uważa się, że język prawny stanowi rejestr języka etnicznego. Jest zatem specyficznym sposobem jego użycia ${ }^{17}$.

W literaturze przedmiotu wskazuje się, że takie rozumienie języka wywołało - z punktu widzenia semiotyki (ogólnej teorii znaku) - zainteresowanie pragmatyczną funkcją języka. Przy czym jego aspekt syntaktyczny (reguły tworzenia znaku) oraz semantyczny (znaczenie nazwy jako związek z rzeczywistością, czyli tym, co ona oznacza) zeszły na drugi plan. Przestajemy zatem interesować się wspólną dla rejestru prawnego i języka etnicznego gramatyką oraz wspólnym słownikiem. Koncentrujemy się natomiast na tzw. wykonawstwie językowym, a zatem na twórczej roli wypowiedzi językowej i jej oddziaływaniu na rzeczywistość, jak na przykład wykonując tzw. czynności konwencjonalne, co zdecydowanie zbliżyło polską szkołę logiczną do oksfordzkiej szkoły analitycznej ${ }^{18}$.

Trzeba mieć również na uwadze i to, że niektóre z kluczowych dla języka prawnego terminów nie zostały zdefiniowane w ustawie, ale funkcjonują w oparciu o dorobek doktryny. Doskonałym tego przykładem jest pojęcie

14 Tekst jednolity: Dz.U. 2020 poz. 1444.

15 S. Lewandowski, H. Machińska, A. Malinowski, J. Petzel, Logika..., s. 24.

16 Por. M. Zirk-Sadowski, Wprowadzenie do filozofii prawa, s. 106.

17 Ibidem, s. 107.

18 Por. ibidem, s. 107-108. 
czynności prawnej. Zatem w skład języka prawnego niewątpliwie wchodzą pozaustawowe definicje ${ }^{19}$.

Sama również definicja czynności prawnych wskazuje na otwartość języka prawnego. Nie ma w nauce prawa całkowitej zgody co do definicji czynności prawnych. Największą jednak estymą cieszy się ta stworzona przez wielki autorytet polskiej nauki i praktyki prawa cywilnego - Aleksandra Woltera. Przez czynności prawne rozumiał on „stan faktyczny, w skład którego wchodzi co najmniej jedno oświadczenie woli, zmierzające do ustanowienia, zmiany lub zniesienia stosunku cywilnoprawnego, z którym to stanem faktycznym ustawa wiąże skutki prawne nie tylko wyrażone w oświadczeniu woli, lecz także oświadczeniem tym nieobjęte, a wynikające z ustawy, zasad współżycia społecznego lub ustalonych zwyczajów"20.

Powyższa definicja może posłużyć za punkt wyjścia do namysłu o ogólnym charakterze. Reprezentuje ona bowiem właściwy dla prawników sposób rozumowania. Wskazuje ona, że ustawa przewiduje skutki wypowiadania pewnych słów, przy czym skutki te nie zawsze są objęte treścią samej wypowiedzi, ale mogą wynikać z zasad współżycia społecznego lub ustalonych zwyczajów. Niemniej skutki owe wynikają, ponieważ ustawa tak stanowi, a nie dlatego, że istnieją inne niż sama ustawa źródła, z których można je wywodzić. Mamy zatem do czynienia ze swoistym paradoksem. Z jednej bowiem strony, wskazuje się, że część definicji języka prawnego ma źródła pozaustawowe, $z$ drugiej zaś - ta pozaustawowa definicja czynności prawnej wskazuje na ustawę jako jedyne źródło, z którego wywodzić można skutki prawne. Z trzeciej zaś, skutki oświadczeń woli wykraczają poza treść ustawy, bowiem dookreślają je zasady współżycia społecznego i ustalone zwyczaje.

Dla zachowania logicznej spójności konieczne jest, by ustawa przewidywała wszystkie skutki oświadczenia woli albo stwierdzała, że to nie wyłącznie z ustawy wywodzić należy wszelkie skutki czynności prawnych. Samo zapisanie w ustawie, że są ustalone zwyczaje lub inne zasady i należy je uwzględniać nie oznacza, że bez ustawy owe zwyczaje i zasady przestałyby obowiązywać. Na to jednak wskazuje przytoczona definicja czynności prawnych, co jest oczywistym paradoksem, jeżeli wskazuje ona, że to z ustawy owe zasady i zwyczaje miałyby czerpać moc obowiązującą, a nie z pozaustawowego porządku normatywnego.

19 E. Skowrońska-Bocian, Prawo cywilne. Część ogólna. Zarys wykładu, Warszawa 2005, s. 169.

20 A. Wolter, Prawo cywilne. Zarys części ogólnej, Warszawa 1967, s. 220. Za: E. Skowrońska-Bocian, Prawo cywilne..., Warszawa 2005, s. 169. 
Pierwszą możliwość - zgodną z założeniami pierwotnego pozytywizmu prawnego - należy odrzucić jako nierealną. Jak zostało wskazane, takie spojrzenie jest nie do pogodzenia $\mathrm{z}$ funkcjonującym w Polsce systemem prawnym. Pozostaje zatem druga możliwość. Ustawa bowiem sama nie może stanowić dla siebie uzasadnienia. Poza ramami niniejszej publikacji znajduje się odpowiedź na pytanie, co stanowi owo uzasadnienie, niewątpliwie jednak znajdować musi się ono poza obszarem prawa stanowionego. Pogląd taki w rażący sposób podważa założenia pierwotnego pozytywizmu prawnego. Interesującym jest jednak danie odpowiedzi na pytanie, czy podważa również założenia wyrafinowanego pozytywizmu prawnego. Pytanie to sprowadza się do tego, czy prawo można utożsamić z ustawą. W myśl pierwotnego pozytywizmu prawnego odpowiedź brzmi „tak”, jednak w myśl wyrafinowanego pozytywizmu prawnego - „nie”. Problem ten będzie przedmiotem rozważań kolejnych rozdziałów.

$\mathrm{Z}$ zagadnieniem języka prawnego związany jest również problem wykładni prawa. Najprościej mówiąc, wyróżnia się dwie koncepcje wykładni prawa: klasyfikacyjną oraz derywacyjną. Pierwsza, zgodnie z zasadą clara non sunt interpretanda, wskazuje, że wykładni dokonuje się wyłącznie wtedy, gdy w treści przepisu pojawia się niejasność. W myśl drugiej, zgodnie z zasadą: omnia sunt interpretanda, zawsze istnieje konieczność odkodowania normy z przepisu, nawet jeśli jest on jasny ${ }^{21}$.

O powyższym sporze można by napisać osobną monografię. Wskazać jednak należy, że więcej argumentów przemawia za koncepcją derywacyjną, przy czym pierwszeństwo przypada wykładni językowej. Akademickim przykładem może być wskazanie na art. 148 Kodeksu karnego ${ }^{22}$, który w $\$ 1$ stwierdza, że ten: „kto zabija człowieka, podlega karze pozbawienia wolności na czas nie krótszy (...)”. Treść tego przepisu nie budzi żadnych wątpliwości. Zabicie człowieka jest czynem, za dokonanie którego ustawodawca przewidział karę. Jest to jednak przeświadczenie błędne, albowiem w części ogólnej Kodeksu karnego, w art. $25 \$ 1^{23}$ czytamy, że ,nie popełnia przestępstwa, kto w obronie koniecznej odpiera bezpośredni, bezprawny zamach na jakiekolwiek dobro chronione prawem". Zatem nie jest prawdą, że zawsze karze podlega ten, kto zabija człowieka, albowiem karze takiej nie podlega ktoś, kto czyni to w obronie koniecznej ${ }^{24}$. Jest to jeden $\mathrm{z}$ wielu

21 Por. S. Lewandowski, H. Machińska, A. Malinowski, J. Petzel, Logika..., s. 257-258.

22 Tekst jednolity: Dz.U. 2020 poz. 1444.

23 Ibidem.

24 Na marginesie należy wskazać, że karze takiej może nie podlegać również ktoś zabijający człowieka w stanie wyższej konieczności (art. $26 \$ 2$ Kodeksu karnego). 
przykładów wskazujący na to, że normę zawsze należy odkodować z jednostki redakcyjnej, jaką jest przepis ${ }^{25}$.

Istotnym z punktu widzenia niniejszego tekstu jest pytanie, według jakich kryteriów interpretacyjnych ma przebiegać wykładnia. Wyróżnia się m.in. wykładnię językową, systemową, funkcjonalną, celowościową oraz historyczną. Wykładnia językowa ma zawsze pierwszeństwo, pozostałe stosuje się subsydiarnie. Wykładnia językowa polega na odkodowaniu normy z przepisu przy użyciu reguł semantycznych i syntaktycznych tak języka potocznego, jak i prawnego ${ }^{26}$. Przy czym - co niezwykle istotne - współcześnie uważa się, że proces wykładni językowej zakończony jest, nie wtedy, gdy jej znaczenie jest jednoznaczne, ale „równocześnie nie budzi wątpliwości natury prakseologicznej oraz aksjologicznej”27. Należy podkreślić, że takie rozumienie wykładni językowej z całą pewnością wykracza poza ramy pierwotnego pozytywizmu prawnego. Analizując poglądy Herberta Harta, należy odpowiedzieć na pytanie, czy rozumienie takie wykracza również poza założenia wyrafinowanego ${ }^{28}$ pozytywizmu prawnego. Odpowiedź, jak się okaże, daleka jest od oczywistości.

Dla porządku należy wskazać, że wykładnia systemowa polega na analizie normy jako elementu niesprzecznego i spójnego systemu prawnego (przyjmuje się założenie o racjonalności ustawodawcy). Funkcjonalna odwołuje się do roli, jaką ma pełnić dana norma w życiu społecznym. Celowościowa usiłuje dociec intencji ustawodawcy (ratio legis), na przykład poprzez analizę uzasadnienia projektu ustawy. Historyczna zaś traktuje normę jako wytwór procesu historycznego, badając jej rozwój - wskazuje na treść, przy czym literalnie przywoływana jest ona niezwykle rzadko.

25 Por. S. Lewandowski, H. Machińska, A. Malinowski, J. Petzel, Logika..., s. 258

26 Por. ibidem, s. 261-264.

27 Ibidem, s. 261.

28 Słowa „wyrafinowany” używa się z uwagi na przekroczenie wąskich ram pierwotnego pozytywizmu prawnego. W przypadku filozofii Herberta Harta owo wyrafinowanie przejawia się m.in. w rozróżnieniu norm prawnych na pierwotne oraz wtórne. 


\subsection{PRZYKeAdy OCZYWISTEJ OTWARTOŚCI STRUKTURY POLSKIEGO JĘZYKA PRAWNEGO}

Warto mieć na uwadze to, że mówiąc o otwartości języka prawnego, nie dokonujemy postępu, a wracamy jedynie do źródeł. Już Rzymianie zdawali sobie sprawę, że: „omnis definitio in iure civili periculosa est: parum est enim, ut non subverti posset”29, co tłumaczy się dziś: „wszelka definicja w prawie cywilnym jest niebezpieczna, ponieważ rzadko się zdarza, by nie można było jej obalić" ${ }^{30}$.

Powyższa paremia (ugruntowana w kulturze sentencja wyrażająca zasadę prawną) wskazuje na trudności, jakie napotyka ustawodawca, tworząc akty prawne. Nie jest bowiem możliwym stworzenie przepisów na tyle kazuistycznych, by odpowiadały każdej możliwej do zaistnienia sytuacji. Oczywiście problem ten schodzi na dalszy plan w systemach Common Law. W systemie prawa kontynentalnego ma jednak kluczowe znaczenie.

Polski ustawodawca w $\$ 155$ załacznika do Rozporzadzenia Prezesa Rady Ministrów z dnia 20 czerwca 2002 r. w sprawie „Zasad techniki prawodawczej" ${ }^{31}$ wyróżnia trzy metody uelastycznienia tekstu prawnego: poprzez wyrażenia nieostre, klauzule generalne oraz wyznaczenie granic swobody rozstrzygnięcia. Przy czym zabiegi uelastyczniające stanowią wyjątek od generalnej zasady precyzyjności tekstu prawnego określonej $\mathrm{w} \$ 6$ powyższego załącznika.

Wyznaczenie granic swobody rozstrzygnięcia nie wiąże się bezpośrednio $\mathrm{z}$ otwartością samego języka prawnego, ale z zapewnieniem sędziemu lub organowi administracji władzy dyskrecjonalnej, na przykład pozostawiając mu decyzję co do wymiaru kary przy uwzględnieniu wskazań natury ogólnej.

Nie wymagają także dłuższego komentarza „wyrażenia nieostre”. Są to bowiem nazwy, których zakres celowo nie jest precyzyjnie określony, na przykład „nieskazitelność charakteru”, „rękojmia prawidłowego wykonywania zawodu”, „w szczególnie uzasadnionych wypadkach”, „istotna wada”, „znaczny upływ czasu” itp. Wyrażenia te również poszerzają zakres władzy dyskrecjonalnej, albowiem to sąd lub organ administracji decydują o tym, co stanowi desygnat danej nazwy - zawsze jednak w granicach ustawy.

29 Jawolenus w: Iustiniani, Corpus Iuris Civilis, vol. I, Digesta vel Pandectae, liber 50.17.202, http:/ droitromain.upmf-grenoble.fr/Corpus/d-50.htm\#17 (dostęp z dnia 17 września 2020 r.).

30 W. Wołodkiewicz, M. Zabłocka, Prawo rzymskie..., s. 8. W publikacji użyte jest inne niż w oryginale słowo: „potest”, zamiast „posset”. Nie ma to jednak wpływu na poprawność polskiego tłumaczenia.

31 Dz.U. 2002 nr 100, poz. 908 z późn. zm. 
Najbardziej interesujące z punktu widzenia niniejszego tekstu są klauzule generalne. Wśród przedstawicieli doktryny toczą się spory co do ich definicji. „Niemniej najprościej klauzulą generalną można nazwać część przepisu zawierającą odesłanie do pozaprawnego systemu ocen, inaczej mówiąc, upoważniającą podmiot stosujący prawo do oparcia decyzji na wskazanych kryteriach pozaprawnych"32. Przy czym w literaturze przedmiotu trwa spór, na ile klauzule te pozwalają organowi stosującemu prawo na odwołanie do subiektywnego systemu wartości, na ile zaś do uzasadnionych aksjologicznie powszechnie akceptowanych zasad ${ }^{33}$. Abstrahując od powyższego sporu, nie ulega wątpliwości, że z punktu widzenia polskiego prawodawcy sama możliwość odwołania się do kryteriów pozaprawnych wynika z woli ustawodawcy, nie zaś z mocy owych pozaprawnych systemów normatywnych. Przykładami klauzul generalnych są na przykład: „dobro dziecka”, „chrześcijański system wartości”, „godziwość wynagrodzenia za pracę", „dobre obyczaje” itp.

Najbardziej charakterystycznym przykładem zastosowania przez ustawodawcę klauzul generalnych jest art. 5 Kodeksu cywilnego ${ }^{34}$, określający nadużycie prawa podmiotowego: „nie można czynić ze swego prawa użytku, który by był sprzeczny ze społeczno-gospodarczym przeznaczeniem tego prawa lub z zasadami współżycia społecznego. Takie działanie lub zaniechanie uprawnionego nie jest uważane za wykonywanie prawa i nie korzysta z ochrony".

Przepis ten zawiera dwie klauzule generalne: „społeczno-gospodarcze przeznaczenie prawa”, oraz „zasady współżycia społecznego”. W największym skrócie treść jego sprowadza się do wyznaczenia granic, w jakich podmiot prawa może ze swych uprawnień korzystać. Przekraczając granice określone we wskazanych klauzulach, podmiot taki nie działa $\mathrm{w}$ ramach prawa i nie może korzystać $\mathrm{z}$ ochrony, jaką ustawa wiąże z posiadaniem danych uprawnień. Przeciwnie zaś, osoby narażone na skutki jego działań mogą podjąć szereg działań prawem przewidzianych w celu uniknięcia zagrożenia lub przywrócenia stanu poprzedniego, jak też zmierzających do naprawienia doznanej szkody (w związku z innymi przepisami Kodeksu cywilnego i innych ustaw).

32 M. Kokoszczyński, Komentarz do zał. \$155 rozporządzenia w sprawie „Zasad techniki prawodawczej”, teza 5, System Informacji Prawnej LEX 2020.

33 Ibidem, teza 6.

34 Tekst jednolity: Dz.U. 2019 poz. 1145 z późn. zm. 
Podsumowując dotychczasowy wywód, należy powiedzieć, że polski język prawny jest językiem otwartym na pozaprawne systemy normatywne. Otwartość ta jednak nie rozwiązuje podstawowego problemu. Pytanie brzmi: co uzasadnia odwołania do owych pozaprawnych systemów? Czy jest to wyłącznie wola ustawodawcy wyrażona w normach powszechnie obowiązującego prawa, czy też istnieją normy, których uzasadnienie leży poza wolą ustawodawcy?

Celem przeprowadzonego wywodu było ukazanie, że odpowiedzi na powyższe pytanie nie sposób odnaleźć, analizując sam system prawa stanowionego. Ustawodawca bowiem, z natury rzeczy, nie może rozstrzygnąć w przepisach prawnych, czy jego wola jest ważniejsza, czy też supremacja należy się na przykład normom aksjologicznym uznawanym przez daną społeczność. Jak bowiem miałby tego dokonać? Wskazać należy, że wszelkie odwołania w tekstach prawnych do kryteriów prawno-naturalnych, wyższych wartości, woli Boga itp. nie rozwiązują w żaden sposób problemu, bowiem to zawsze ustawodawca wskazuje na owe wartości. Nie może on w akcie normatywnym skutecznie wykazać, że owe kryteria pozaprawne są ważniejsze, skoro to on rozstrzyga o ich obecności w tym akcie.

Mamy zatem do czynienia z paradoksem. Uznając moc obowiązującą prawa natury (jakkolwiek rozumianego) i domagając się jego zapisania w akcie prawnym, de facto degradujemy jego status, ponieważ samo zapisanie sprowadza je do roli podrzędnej w stosunku do deklarującego jego istnienie ustawodawcy. Treść prawa natury winna być od woli ustawodawcy niezależna.

W takiej sytuacji należy domagać się otwartości systemu prawnego na oceny oparte na kryteriach pozaprawnych chociażby poprzez możliwość kierowania postulatów co do obowiązującego lub przyszłego prawa, jak i też praktyki jego stosowania. Poszerzenie samej jednak metody prawoznawstwa o kryteria aksjologiczne budzi zastrzeżenia natury logicznej.

Prawo jawi się jako jedna $\mathrm{z}$ wielu narracji. Ma ono porządkować życie społeczne, nie zaś całkowicie je zawłaszczać. Musi być zatem także otwarte na narracje wywodzące swe oceny ze źródeł natury aksjologicznej, w tym etycznej.

Z powyższego zdawał sobie sprawę Herbert Hart, tworząc swoją koncepcję wyrafinowanego pozytywizmu prawnego. Analiza jego poglądów ułatwi rozwiązanie zarysowanego dylematu. 


\section{Elementy filozofii prawa Herberta Harta}

Niniejszy rozdział jest kluczowym elementem publikacji. Jego celem jest przedstawienie filozofii prawa Herberta Harta $\mathrm{w}$ istotnych $\mathrm{z}$ punktu widzenia aktualnego dyskursu filozoficznego aspektach. W literaturze przedmiotu podkreśla się jej niejednolite rozumienie ${ }^{1}$. Kontrowersje budzi przede wszystkim krytyczna interpretacja jego dzieł dokonana przez Ronalda Dworkina. Replika na ową krytykę zawarta jest w posłowiu do aktualnego wydania Pojęcia prawa (napisanego 30 lat po ukazaniu się pierwszego wydania). W niniejszej publikacji autor przyjmuje metodę polegającą na interpretacji filozofii Harta poprzez pryzmat wspomnianej repliki. W tym celu przedmiotem podrozdziału 3.1 staną się uwagi wprowadzające, bazujące na jej tezach. Ich przedstawienie wydaje się konieczne dla uniknięcia błędnej interpretacji dorobku Harta. W szczególności istotny jest tu stosunek Harta do ogólnych zasad prawa. Koncepcja Dworkina nie zostanie przedstawiona w sposób pełny, albowiem wykracza ona poza zakres niniejszej monografii. Autor odwołuje się do niej jedynie tam, gdzie jest to konieczne dla zrozumienia intencji samego Harta.

Podrozdział 3.2 wskazuje na specyficzny sposób rozumowania, jakim posługuje się Hart. Inaczej bowiem postrzega on rolę i istotę definicji w prawie. Dla Polaków wychowanych na osiągnięciach szkoły lwowsko-warszawskiej,

1 M. Zirk-Sadowski, Wprowadzenie do filozofii prawa, s. 197. 
a w szczególności na Kursie logiki dla prawników Kotarbińskiego, jest to różnica na tyle istotna, że wymaga poświęcenia jej osobnego podrozdziału.

Podrozdział 3.3 przedstawia rdzeń poglądów Harta. Zawiera opis reguł pierwotnych i wtórnych, a zatem składników definicyjnych normy prawnej.

Podrozdział 3.4 omawia stosunek Harta do relacji prawa i moralności. Podrozdział 3.5 stanowi analizę jego koncepcji minimalnej treści prawa natury oraz sposobu pojmowania przez niego sprawiedliwości (wynika z niego postulat co do treści prawa natury).

\subsection{UWAGI WPROWADZAJĄCE}

W pierwszym rzędzie należy wskazać, że teoria prawa Herberta Harta zasadniczo rożni się na przykład od teorii Dworkina. Podejście tego pierwszego jest opisowe, a zatem jest neutralne moralnie ${ }^{2}$. Przy czym - co niezwykle istotne - zgłębienie owego opisu ,jest istotnym wstępem do wszelkiej moralnej krytyki prawa"3.

Dla Harta zatem, w przeciwieństwie do Dworkina, teoria prawa nie zajmuje się zasadami o charakterze moralnym, obecnymi zarówno w języku prawnym, jak i w praktyce orzeczniczej. Należy również wskazać, że w opozycji do Dworkina - Hartowska teoria prawa nie zawiera elementów interpretacyjnych ani tym bardziej oceniających ${ }^{4}$.

Główne zagadnienie sporu z Dworkinem dotyczy twierdzenia, że teoria prawa powinna uwzględniać „wewnętrzną perspektywę prawa, która jest światopoglądem uczestnika danego systemu”, przy czym teoria opisowa miałaby - zdaniem Dworkina - być pozbawiona możliwości ujęcia prawa $\mathrm{z}$ takiej perspektywy. Dworkin zatem zarzuca Hartowi, że jego teoria jest niepełna, albowiem nie uwzględnia indywidualnych przekonań użytkowników prawa.

Hart - odpierając powyższy zarzut - wskazuje, że ów wewnętrzny punkt widzenia uczestnika jest w jego teorii uwzględniany, albowiem obowiązkiem zewnętrznego obserwatora jest m.in. opis tych wewnętrznych punktów

\footnotetext{
2 H. L. A. Hart, Pojęcie prawa, s. 320.

3 Ibidem.

4 Ibidem, s. 321-323.

5 Ibidem, s. 323.
} 
widzenia $^{6}$. Wskaźnikiem dla owych wewnętrznych punktów widzenia ${ }^{7}$ jest manifestacja przez uczestników akceptacji „prawa jako zbioru wskazówek postępowania i wzorców krytycznej oceny”.

Nie ma przy tym dla Harta znaczenia, czy sam opisujący podziela ów wewnętrzny punkt widzenia ${ }^{9}$. Istotne jest to, że musi go rozumieć. Hart wskazuje, że „musi umieć postawić siebie samego w miejsce kogoś znajdującego się wewnątrz systemu"10.

Teza, według której dla opisu prawa konieczne jest uwzględnienie zewnętrznego ${ }^{11}$ oraz wewnętrznego punktu widzenia, jest kluczowa dla zrozumienia myśli Harta. Budzi ona zarazem największe trudności interpretacyjne. Przede wszystkim wzbogacenie teorii o wewnętrzny punkt widzenia odróżnia myśl Harta od pierwotnego pozytywizmu prawnego, który uwzględniał jedynie zewnętrzny punkt widzenia. Zewnętrzny punkt widzenia stanowi czysty, empiryczny opis zjawiska prawa, tak jak rozumieli go Austin i przedstawiciele Koła Wiedeńskiego. Jak zostało wykazane w podrozdziale 1.3 , czysty opis empiryczny jest niemożliwy lub nieprzydatny. Konieczne jest więc uwzględnienie wewnętrznego aspektu obserwacji.

Argumentacja samego Harta przebiega odmiennie niż ta przedstawiona przez autora niniejszej publikacji w powyższym akapicie. Nie jest ona jednak sprzeczna z jego poglądami, co więcej, pomaga w zrozumieniu jego myśli oraz potwierdza słuszność wniosków. Hart kładzie nacisk na odróżnienie działania pod przymusem od bycia zobowiązanym. Jego zdaniem, na gruncie pierwotnego pozytywizmu prawnego (uwzględniającego jedynie aspekt zewnętrzny) nie jest możliwe odróżnienie sytuacji podlegania suwerenowi od sytuacji, w której człowiek jest pod władzą bandyty przystawiającego mu pistolet do głowy. Uwzględnienie aspektu wewnętrznego (krytycznego namysłu nad prawem) pozwala Hartowi na sformułowanie tezy, że w sto-

6 Ibidem, s. 323-324.

7 W rozumieniu nadanym temu pojęciu przez metodologię badań empirycznych.

8 H. L. A. Hart, Pojęcie prawa, s. 324.

9 Hart wskazuje, że zarzut Dworkina jest bezzasadny, albowiem jego rozumienie teorii prawa zakłada konieczność rozumienia przez teoretyka opisywanych wewnętrznych punktów widzenia. Dla trafności i rzetelności teorii nie ma znaczenia, czy teoretyk sam podziela opisywany wewnętrzny punkt widzenia.

10 H. L. A. Hart, Pojęcie prawa, s. 324.

11 Przez punkt widzenia rozumie się perspektywę użytkownika prawa, która powinna być właściwie ujęta przez teoretyka opisującego zjawiska prawne. Zewnętrzny punkt widzenia wskazuje na perspektywę, $\mathrm{w}$ jakiej użytkownik prawa godzi się na jego istnienie jedynie $\mathrm{z}$ obawy przed sankcją. Wewnętrzny punkt widzenia to perspektywa, wedle której podmiot prawa używa norm prawnych jako wzorców dla własnych i cudzych zachowań. Terminu zbliżonego do „wewnętrznego punktu widzenia” używa Joseph Raz, stosując termin „prawny punkt widzenia”, wskazujący na wiarę w moc obowiązującą norm prawnych. 
sunku do suwerena człowiek jest zobowiązany, a względem bandyty podlega jedynie przymusowi $i^{12}$.

Należy pamiętać (co wynika z przedstawionej polemiki z Dworkinem), że uwzględnienie aspektu wewnętrznego nie prowadzi do porzucenia opisowego charakteru teorii, czy - używając innych słów - do porzucenia empirycznej orientacji. W literaturze przedmiotu podkreśla się specyfikę tego podejścia. Mianowicie nie jest to obserwacja w rozumieniu pozytywistów z Koła Wiedeńskiego, lecz obserwacja, w której pośrednikiem jest język. Badacz jest zarazem obserwatorem języka, jak i jego uczestnikiem ${ }^{13}$.

Bycie uczestnikiem powinno być rozumiane (jak zostało przedstawione w podrozdziale 1.3) jako uczestniczenie w grach językowych. Zatem kluczową rolę w filozofii Harta odgrywa kontekst (patrz podrozdział 3.2). Są to istotne powody, dla których autor niniejszego tekstu dla opisu Hartowskiej wizji prawa używa terminu „narracja”.

Na marginesie należy dodać, że Hart twierdzi, iż podejście Dworkina samo stanowi część sytemu prawnego. Zaciera się zatem granica pomiędzy prawem a teorią prawa ${ }^{14}$. Innymi słowy, krzyżują się zakresy metody badawczej i jej przedmiotu, co podważa naukowość takiej analizy.

Przyjęcie wspomnianego wcześniej opisowego charakteru prawa (zewnętrzna empiryczna perspektywa uwzględniająca indywidualne przekonania użytkowników prawa) pozwoliło Hartowi na przezwyciężenie partykularyzmu kultury anglosaskiej i tworzenie tez natury ogólnej. Przy czym zmusiło go to również do specyficznego rozumienia normatywności: jako reguł rządzących prawem. Samego zaś prawa jako „złożonej politycznej instytucji”"15. Przy czym normatywność - zdaniem Harta - polega na dostarczaniu racji oraz ustalaniu powinności ${ }^{16}$.

Na marginesie należy wskazać, że Hart słusznie zarzuca Dworkinowi, iż ten zniekształcił stworzoną przez niego teorię porządku prawnego ${ }^{17}$. Przede wszystkim z tego powodu, że koncepcja ta nie jest czysto faktualna, albowiem dopuszcza - jako kryteria oceny prawa - nie tylko fakty, ale także wartości. Ponadto nie jest prawdą - jak chce Dworkin - że celem prawa jest dla Harta usprawiedliwienie użycia przemocy ${ }^{18}$.

\footnotetext{
12 H. L. A. Hart, Pojęcie prawa, s. 118-122.

13 M. Zirk-Sadowski, Wprowadzenie do filozofii prawa, s. 190.

14 H. L. A. Hart, Pojęcie prawa, s. 324.

15 Ibidem, s. 320.

16 Ibidem, s. 343

17 Ibidem, s. 330

18 Ibidem, s. 332
} 
Hart uważa, że nie jest możliwym wskazanie specyficznego dla prawa celu poza funkcją regulującą stosunki społeczne. Sugeruje, że jest ono jedną $\mathrm{z}$ wielu narracji porządkujących życie społeczne. Przy czym wyróżnia on cechy charakterystyczne owej narracji w postaci tzw. reguł wtórnych ${ }^{19}$ (Hart nie używa terminu „narracja”, niemniej jego użycie jest uzasadnione z uwagi na wyraźne nawiązania do koncepcji gier językowych oraz rolę kontekstu w jego filozofii).

Być może najdonioślejszym efektem opisywanej polemiki jest włączenie przez Harta do jego teorii prawa postulowanych przez Dworkina zasad pra$\mathrm{wa}^{20}$. Jak wiadomo, w pierwotnej wersji książki Pojęcie prawa Hart definiował prawo jako związek reguł, nie zaś zasad. W zrewidowanej wersji przyznaje on jednak wprost, że w jego teorii również zasady winny być uwzględnione (wskazuje również, że uwzględnienie zasad prawa nie jest sprzeczne $\mathrm{z}$ jego wcześniejszymi poglądami). Wskazuje przy tym, że de facto ich istnienie wynika $\mathrm{z}$ otwartej konstrukcji reguły uznania oraz $\mathrm{z}$ wprowadzenia do teorii prawa wewnętrznego aspektu prawa ${ }^{21}$. Przy czym warto podkreślić, że Hart całkowicie nie zgadza się z twierdzeniem Dworkina, że jego reguły mają charakter konkluzywny (w języku Dworkina: wszystko albo nic). Wielokrotnie wskazuje na ich otwarty charakter ${ }^{22}$.

Istotę zasad można porównać do roli paremii, czyli ogólnych, uświęconych przez tradycję zasad prawa. Ich charakter najlepiej przedstawić na omawianym zarówno przez Dworkina ${ }^{23}$, jak i Harta ${ }^{24}$ przykładzie sprawy Riggs vs. Palmer. Stan faktyczny sprowadza się do tego, że wnuk dziedziczący z mocy pisemnego testamentu po dziadku, dopuścił się jego zabójstwa. Przy czym miał on świadomość, że treść testamentu jest dla niego korzystna, a zabójstwa dokonał $\mathrm{w}$ obawie przed zmianą treści testamentu na rzecz nowej partnerki dziadka. Pytanie brzmi: czy zabójca może dziedziczyć po swej ofierze?

Istotne jest to, że na gruncie prawa USA nie obowiązywała wtedy żadna reguła wyłączająca w takiej sytuacji zabójcę od dziedziczenia. Sąd zastosował

19 Ibidem

20 W rozumieniu utrwalonych w kulturze zasad systemu prawnego, które stanowią podstawę orzeczeń sądowych w sytuacji, gdy prosta subsumpcja jest niewystarczająca. Zdaniem Dworkina zasady w przeciwieństwie do reguł wskazują jedynie kierunek argumentacji, nie wyznaczając go w sposób kategoryczny. Jego zdaniem o zasadności zastosowania zasad decyduje kontekst danej sprawy, a sprzeczność zasad ujawniająca się w danym stanie faktycznym ich nie unieważnia (w przeciwieństwie do reguł).

21 H. L. A. Hart, Pojęcie prawa, s. 347 i 354-357.

22 Ibidem, s. 349-350.

23 R. Dworkin, Biorac prawa poważnie, Warszawa 1998, s. 68.

24 H. L. A. Hart, Pojęcie prawa, s. 350. 
ogólną zasadę (nie regułę) mówiącą, że nie można korzystać z owoców własnej nieuczciwości. Zasada ma zatem charakter bardziej ogólny oraz w pewnych przypadkach może zmodyfikować treść obecnych w systemie reguł.

Na marginesie należy zaznaczyć, że na gruncie polskim, w analogicznym stanie faktycznym, nowa partnerka (lub każdy posiadający w tym interes - w skrajnych sytuacjach również prokurator) może wytoczyć powództwo o uznanie zabójcy za niegodnego dziedziczenia na podstawie art. $928 \$ 1$ punkt 1 Kodeksu cywilnego ${ }^{25}$, ze skutkiem wyłączenia zabójcy od dziedziczenia. Widać zatem, że zasady prawa mają doniosłe znaczenie także w polskim prawodawstwie. Odgrywają one jednak nieco odmienną rolę. Mają bowiem fundamentalne znaczenie na etapie tworzenia przepisów. Niemniej nie sposób również przecenić ich roli na etapie interpretowania istniejących norm. Sąd bowiem - w wyjątkowych przypadkach - ma możliwość odstąpienia od wykładni literalnej na rzecz wykładni teleologicznej (patrz podrozdział 2.2). Ponadto polski system prawa zawiera dużą liczbę spisanych zasad prawa, przez pryzmat których interpretuje się normy niższego rzędu (w niektórych sytuacjach stosuje się je bezpośrednio). Takim zbiorem zasad prawa jest oczywiście Konstytucja RP, a jednym z wielu przykładów zasad może być treść art. 2: „Rzeczpospolita Polska jest demokratycznym państwem prawnym, urzeczywistniającym zasady sprawiedliwości społecznej"26. O każdej z zapisanych w Konstytucji zasad można by napisać osobny tekst. Kończąc powyższy wątek, warto dodać, że współcześnie sądy bardzo niechętnie odstępują od literalnego brzmienia przepisu, co związane jest z ogólnym upadkiem kultury prawnej, wynikającym z prymatu rozumu instrumentalnego (odstąpienie od literalnej wykładni wiąże się z niemal pewnym sporządzeniem środka odwoławczego, a w wypadku jego skuteczności - $\mathrm{z}$ utrudnieniem awansu sędziego). 


\subsection{SPECYFIKA ROZUMIENIA PRZEZ Herberta Harta POJĘć PRAWNYCH}

Wskazać należy na zasadniczą odmienność postrzegania roli definicji przez analityczną szkołę oksfordzką w stosunku do rodzimego poglądu ugruntowanego na osiągnięciach szkoły lwowsko-warszawskiej. Tę pierwszą cechuje swoista niechęć do formułowania klasycznych, równoważnych definicji, tworzonych poprzez podanie rodzaju najbliższego i różnicy gatunkowej. Zdaniem Harta, definicje te w odniesieniu do ogólnych pojęć prawnych są albo bezużyteczne, albo mylące ${ }^{27}$. Za Benthamem powtarza, że „nigdy nie należy brać terminów prawnych osobno, ale rozważać całe zdania, w których pełnią swoje charakterystyczne role"28. Hart w sposób oczywisty nawiązuje zatem do koncepcji gier językowych Wittgensteina, opisanych w poprzednim rozdziale.

Koncepcja prawa jako związku reguł rozumiana zatem powinna być jako alternatywa dla prawa definiowanego w sposób klasyczny. Zdaniem Harta, pojęcie „prawo”, a także inne podstawowe i ogólne pojęcia, takie jak „uprawnienie”, „państwo” czy „osoba prawna”29, mogą być zrozumiałe jedynie przy ukazaniu kontekstu, w jakim funkcjonują ${ }^{30}$. Hart dla zobrazowania owego zagadnienia posługuje się szeregiem barwnych analogii. Uważa na przykład, że nie sposób wyjaśnić, co to jest „lewa”, bez ukazania kontekstu, tj. reguł gry w karty ${ }^{31}$.

Ukazany wyżej sposób myślenia opiera się na popularnej dla oksfordzkiej szkoły analitycznej koncepcji presupozycji. Mianowicie, zdanie $B$ jest w pełni zrozumiałe jedynie w odniesieniu do zdania $A$, przy czym zdanie $B$ jest

27 H. L. A. Hart, Eseje z filozofii prawa, Warszawa 2001, s. 32.

28 Ibidem, s. 26.

29 Pojęcie osoby prawnej na gruncie polskiego sytemu prawnego nie jest najlepszym przykładem ukazującym wady klasycznych definicji. Przede wszystkim w polskiej kulturze prawnej wypracowane zostały precyzyjne definicje zdolności prawnej oraz zdolności do czynności prawnych. Na gruncie Common Law pojęcie osoby prawnej wykształciło się na drodze precedensu, w dużej mierze poprzez stosowanie analogii do pojęcia osoby fizycznej, a zatem kontekst, w jakim funkcjonowały normy, miał (i ma) znaczenie fundamentalne, inaczej niż na gruncie prawa polskiego, gdzie funkcjonuje precyzyjne rozróżnienie osób fizycznych, osób prawnych oraz tzw. ułomnych osób prawnych (jednostek organizacyjnych nieposiadających osobowości prawnej, którym ustawodawca przyznał zdolność prawną). Niemniej również u nas kontekst miał fundamentalne znaczenie na etapie tworzenia definicji ustawowych (oraz na etapie rozważania ich treści przez przedstawicieli doktryny). Ma on także znaczenie przy stosowaniu owych definicji do konkretnego stanu faktycznego.

30 H. L. A. Hart, Eseje z filozofii prawa, s. 31.

31 Ibidem, s. 33. 
prawdziwe przy założeniu prawdziwości zdania $A$. Zdanie $A$ jest presupozycją zdania $B$, a zatem warunkiem jego prawdziwości i pełnego zrozumienia ${ }^{32}$.

Wykorzystanie konstrukcji presupozycji prowadzi oczywiście do problemu regresu w nieskończoność. Zawsze bowiem istnieć musi jakiś gwarant prawdziwości poprzedniego zdania. Nie jest to publikacja z zakresu logiki, warto jednak wskazać, że problem ten próbowano rozwiązać rozmaicie. Jedną z prób była koncepcja normy podstawowej Kelsena, nawiązująca do filozofii Kanta $^{33}$. Inną próbą jest wykazanie niesprzeczności logicznej norm, które odnoszą się same do siebie. $\mathrm{Z}$ tą ostatnią zgadza się Hart, wskazując m.in. na funkcjonowanie norm regulujących procedurę zmiany samych siebie. Poszukując analogicznego przykładu do przedstawionego przez Harta, należy wskazać sytuację, gdy ustawodawca zapragnąłby zmiany art. 235 Konstytucji $\mathrm{RP}^{34}$, przy czym art. ten reguluje procedurę uchwalania zmian w Konstytucji, a zatem w zaistniałej sytuacji odnosiłby się sam do siebie. Nie wgłębiając się w szczegóły, należy wskazać, że dla Harta taka sytuacja nie rodzi zastrzeżeń natury logicznej. Dopuszcza on zatem sytuację samoodnoszenia się norm prawnych i nie traktuje tego zjawiska jako błędnego koła ${ }^{35}$.

Niezwykle ważnym dla zrozumienia myśli Harta jest dostrzeżenie, że prawo jest dla niego zjawiskiem społecznym, obok innych zjawisk społecznych, takich jak moralność. Przy czym zjawiska te są różne, lecz wzajemnie powiązane ${ }^{36}$.

Prawo jawi się zatem jako część kultury. Jest jedną z tworzących ją narracji. Jednocześnie nie rości sobie pretensji do dominacji nad pozostałymi. Brak hierarchii tych narracji może być traktowany jako podstawowy zarzut, który można postawić opisywanej koncepcji. Złagodzony jest on jednak przez koncepcję minimalnej treści prawa natury, która będzie przedmiotem dalszych rozważań. Na tym etapie warto już jednak zaznaczyć, że

32 H. L. A. Hart, Pojęcie prawa, s. XX, wstęp tłumacza.

33 Norma podstawowa Kelsena jest odpowiednikiem kategorii transcendentalno-logicznych Kanta. Kelsen przeformułował Kantowskie pytanie ,jak możliwe jest matematyczne przyrodoznawstwo?”, na pytanie ,jak możliwe jest prawoznawstwo?”. W oparciu o Kantowskie sondy syntetyczne a priori, wskazał, że metoda prawoznawstwa jest formą dla przepisów prawa, które bez owej formy stanowią wyłącznie materiał alogiczny, Przy czym normatywność zawiera się oczywiście w owej formie (metodzie prawoznawstwa). Różnica między przyrodoznawstwem a prawoznawstwem polega na tym, że poprzednik i następnik zdań tego pierwszego łączą związki przyczynowo-skutkowe, w prawoznawstwie zaś związki powinności. Kelsen uzasadnienie prawa pozytywnego wywodzi z koniecznych logicznie wniosków rozumu teoretycznego, nie zaś rozumu praktycznego (jak Kant). Prowadzi to do radykalnego oddzielenia sfery bytu i powinności (z punktu widzenia etyki istotne jest to, że uzasadnienie prawa pozytywnego pozbawione jest wszelkich związków z rozumem praktycznym - inaczej niż u Kanta).

34 Dz.U. 1997 nr 78 poz. 483, z późn. zm.

35 Por. H. L. A. Hart, Eseje z filozofii prawa, s. 173-176.

36 H. L. A. Hart, Pojęcie prawa, s. 3. 
bez odniesienia do prawa natury (choćby w minimalnym zakresie) nie jest możliwa ocena zasadności żadnej z narracji, czy to prawnej, czy moralnej. Każda bowiem ma swój punkt widzenia. Posługując się skrajnym przykładem procesów norymberskich, wskazać trzeba, że bez odniesienia do prawa natury procesy te byłyby jedynie zemstą zwycięzcy nad przegranym, nie zaś realizacją idei sprawiedliwości czy wymogiem prawa.

\subsection{PraWo JAKo ZWIĄZEK REgul PIERWOTNYCH I WTÓRNYCH}

Hart, twierdząc, że prawo jest związkiem reguł (pierwotnych i wtórnych), wskazuje jednocześnie, że jest to nowa perspektywa postrzegania zjawisk prawnych. Opiera się ona na krytyce pierwotnego pozytywizmu prawnego, który okazał się dalece niewystarczający. Analiza obowiązujących systemów prawnych doprowadziła Harta do konkluzji, że prawo jest czymś więcej niż tylko rozkazem suwerena zabezpieczonym przymusem ${ }^{37}$.

Hart przedstawia szereg argumentów pochodzących z przeglądu obecnie obowiązujących systemów prawnych. Analizuje na przykład prawo karne, które wydaje się najbliższe koncepcji rozkazu, wskazuje, że obowiązuje ono również tego, który je uchwalił. I twierdzi, że nie jest to zatem rozkaz ${ }^{38}$.

Jest to argument jak najbardziej trafny, również na gruncie polskiego systemu prawa. Art. 32 ust. 1 Konstytucji $\mathrm{RP}^{39}$ wprowadza zasadę równości wobec prawa, zaś art. 4 ust. ${ }^{40}$ zasadę suwerenności narodu ${ }^{41}$ (jako wspólnoty historyczno-kulturowej). Można więc powiedzieć, że uzasadnienie obowiązywania prawa w Polsce opiera się na woli narodu, który z oczywistych względów sam poddany jest owemu prawu ${ }^{42}$.

37 Ibidem, s. 114

38 Ibidem.

39 Dz.U. 1997 nr 78 poz. 483, z późn. zm.

40 Ibidem.

41 Ustawodawca przywołując pojęcie „Narodu”, używa wielkiej litery, co samo w sobie stanowi podkreślenie jego roli w uzasadnieniu systemu prawnego.

42 Czytającemu te słowa może wydawać się, że jest to egzemplifikacja idei umowy społecznej. Pamiętać jednak trzeba, że Konstytucja w swej preambule zawiera odwołanie do wartości. Ponadto sama treść aktu prawnego w żadnym razie nie przesądza o istnieniu i charakterze prawa naturalnego czy powszechnie stosowanych zasad prawa międzynarodowego (w ostatnim przypadku nauka prawa również daleka jest od jednoznacznych konkluzji). 
Warto podkreślić, że wspomniany art. 4 ust. 1 Konstytucji RP posiada dwa aspekty: negatywny i pozytywny. Negatywny jest zabezpieczeniem przed powrotem monarchii absolutnej. Mianowicie wskazuje, że monarcha nie może być suwerenem, albowiem może być nim jedynie naród jako całość, nie zaś wyodrębniona grupa społeczna czy klasa, jak w Konstytucji PRL (lud pracujący miast i wsi). W sensie pozytywnym artykuł ten wymaga zdefiniowania pojęcia narodu. Przy czym zarówno dla praktyki sądowej, jak i zdaniem przedstawicieli doktryny (prawoznawstwa), jest to pojęcie o charakterze nie etnicznym, ale filozoficzno-społecznym ${ }^{43}$. Powyższa teza jest niezwykle istotna, albowiem stanowi przykład otwartości prawa na treści dostarczane przez inne niż prawoznawstwo dziedziny wiedzy (w tym przypadku na przykład przez filozofię społeczną lub socjologię). Ustawodawca nie definiuje w konstytucji pojęcia narodu. Niewątpliwie posługuje się jednak jakimś rozumieniem tego słowa, wykraczającym poza formalne ramy obywatelstwa (na przykład art. 6 ust. 2 Konstytucji RP) ${ }^{44}$.

Hart podaje również inne przykłady norm niemieszczących się w zakresie Austinowskiej definicji prawa. Mianowicie, wskazuje na istnienie norm ustrojowych, ustanawiających kompetencje do orzekania ${ }^{45}$. W polskim systemie prawnym za przykład takich norm mogą posłużyć przepisy rozdziału VIII Konstytucji RP ${ }^{46}$, określające kompetencje sądów i trybunałów.

Innym przykładem obalającym koncepcję pierwotnego pozytywizmu prawnego w odniesieniu do definicji prawa są przepisy nadające kompetencje do zawiązywania, rozwiązywania i zmiany stosunków prawnych. Na polskim gruncie przykładem jest art. 353 indeks jeden Kodeksu cywilnego ${ }^{47}$, wyznaczający granice swobody umów. Wskazuje on, że „strony zawierające umowę mogą ułożyć swój stosunek prawny według swego uznania, byleby jego treść lub cel nie sprzeciwiały się właściwości (naturze) stosunku, ustawie ani zasadom współżycia społecznego"48. Przepis ten w oczywisty sposób nie jest rozkazem. Wskazuje on również na otwartość prawa. Zawiera bowiem klauzulę generalną oraz odwołanie do natury stosunku prawnego. Nawiązuje zatem do kategorii pozaprawnych. Zastosowanie go wyłącznie w drodze operacji logicznych dokonywanych na przepisach prawa stanowionego, jak chciał Austin, byłoby niemożliwe.

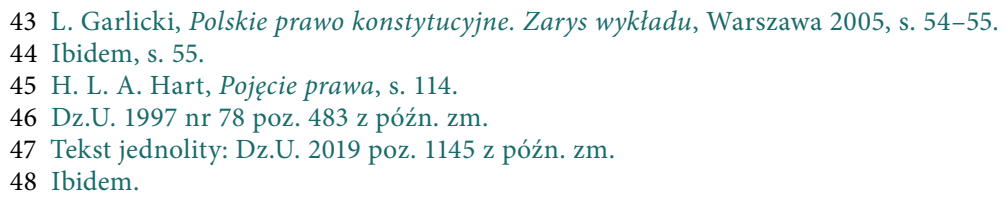


Podkreślić należy, że Hart uważał definicję prawa podaną przez Austina nie tyle za błędną, co za niewystarczającą. Normy, które niezależnie od woli adresata nakazują działanie lub powstrzymanie się od działania - a zatem wyczerpujące Austinowską definicję prawa - nazwał Hart regułami pierwotnymi (podstawowymi). Ich istota sprowadza się do nakładania obowiązków ${ }^{49}$.

Dla pełni opisu zjawisk prawnych konieczne jest wyróżnienie również tzw. reguł wtórnych. Wtórnych, albowiem bazujących na regułach nakładających obowiązki. Ich istotą jest kreacja kompetencji publicznych i możności prywatnych ${ }^{50}$. Bazują one na regułach pierwotnych w tym sensie, że „ludzie mogą przez uczynienie lub powiedzenie czegoś wprowadzić nowe reguły pierwotne, odwoływać lub modyfikować stare lub też na różne sposoby określać ich zasięg i działanie" ${ }^{51}$. Ich wtórność jest zatem specyficznie rozumiana.

Pierwotności i wtórności nie należy rozumieć w kategoriach ważności czy pierwszeństwa. Nie sposób bowiem określić hierarchii reguł. W szczególności wydaje się, że reguły wtórne mogą stać się regułami pierwotnymi. Trudno też wskazać, które konkretnie reguły wytworzone zostały w procesie historycznym wcześniej. W prawie rzymskim, na przykład, wyróżnić można również ustrojowe normy kompetencyjnie (i to w szerszym zakresie niż obecnie - jak choćby wspomniane w podrozdziale 2.1 niniejszego tekstu ius respondenci czy kompetencje sądownicze pretorów). Również opis praw starszych niż rzymskie wykracza poza zakres reguł pierwotnych. Problemu tego Hart nie rozważa. Podaje jednak przykład ludów pierwotnych, które nie wykształciły reguł wtórnych ${ }^{52}$. Traktować to należy - zdaniem autora niniejszej publikacji - jako przykład mający ułatwić zrozumienie koncepcji prawa jako związku reguł pierwotnych i wtórnych, nie zaś badania historyczno-prawne czy socjologiczno-prawne.

Niemniej, pamiętać należy, że geneza reguł może być zwyczajowa oraz że dla jej zaistnienia konieczna jest groźba sankcji za jej przekroczenie, chociażby w formie negatywnej reakcji otoczenia społecznego ${ }^{53}$.

Hart utrzymuje, że dla zaistnienia obowiązku nie wystarczy przewidywanie wystąpienia negatywnych skutków przekroczenia reguły (nazywa taką perspektywę zewnętrznym aspektem reguł). Konieczne jest uwzględnienie aspektu wewnętrznego. Ów wewnętrzny aspekt sprowadza się do poszuki-

49 H. L. A. Hart, Pojęcie prawa, s. 116-117.

50 Ibidem.

51 Ibidem.

52 Ibidem, s. 130.

53 Ibidem, s. 123-124. 
wania racji danej reguły, czyli w rozumieniu Harta - przyczyny, dla której większość społeczeństwa podporządkowuje się danej regule ${ }^{54}$.

Chcąc zobrazować różnicę między wspomnianymi aspektami reguł, przywołuje sygnalizację świetlną i regułę nakazującą zatrzymać się na czerwonym świetle. Aspekt zewnętrzny polegałby tu na zestawieniu danych zebranych przez zewnętrznego obserwatora. $Z$ danych tych wynika, że pojawienie się czerwonego światła pozwala przewidzieć, że z wysokim prawdopodobieństwem zatrzymają się przed sygnalizacją świetlną uczestniczy ruchu. Jest to niezwykle istotna informacja, ale nie oddaje całości znaczenia reguły. Dla pełnego oglądu konieczne jest zbadanie tego, jak kierowca odnosi się do owej reguły, a zatem jaka jest dla niego racja jej przestrzegania. Przy czym chodzi nie o pojedynczego człowieka, ale o przeciętnego przedstawiciela danej społeczności ${ }^{55}$.

Warto pamiętać, że koncepcja wewnętrznego aspektu reguł wywołała kontrowersje. Hart w replice na zarzuty Dworkina (uwzględnienie perspektywy obserwatora w teorii prawa miało zdaniem Dworkina wykraczać poza opisową teorię prawa) wyraźnie wskazuje, że wewnętrzny charakter reguł w żadnym razie nie pozbawia jego teorii charakteru opisowego, co zostało omówione w podrozdziale 3.1 niniejszego tekstu.

Podkreślić należy, że dla Harta o ważności (doniosłości) danej reguły świadczy wyłącznie to, jak jest ona postrzegana przez przedstawicieli danej społeczności (ich większość). Zatem jest to uzasadnienie jedynie empiryczne. Nie poszukuje on uzasadnienia w nakazach czystego rozumu, czy tym bardziej w przesłankach metafizycznych. Jest to jedynie opis tego, czym jest prawo. Przy czym jest to opis z perspektywy zarówno obserwatora, jak i uczestnika (co zostało przedstawione w podrozdziale 3.1). Trzeba pamiętać, że dla Harta fundamentem myślenia filozoficznego nie jest metafizyka. Zadaniem filozofii jest pozbycie się „ciemnej metafizyki” ${ }^{5}$.

Powyższa teza jest niezwykle kontrowersyjna. Należy jednak mieć na uwadze to, że Hart wskazuje, czym jest prawo, w żadnym zaś razie nie odpowiada na pytanie, czy tego prawa należy przestrzegać. Jak zostało już powiedziane, prawo jest otwarte na krytykę z pozycji innych rodzajów narracji. Mówiąc prościej, ze zrozumienia tego, czym jest prawo, nie wynika bezwzględny obowiązek jego przestrzegania. Obowiązek taki istniał na gruncie pierwotnego pozytywizmu prawnego, ale też na przykład w koncepcji Kanta

54 Ibidem, s. 126-129.

55 Ibidem, s. 128

56 Ibidem, s. 120 
(w odniesieniu do prawa stanowionego jako warunku wolności i zarazem możliwości zaistnienia czynu moralnego).

Dla zilustrowania powyższej tezy można posłużyć się przykładem społeczności kanibali. Zjadanie ludzi w celach quasi-religijnych jest dla nas trudne do zrozumienia. Nie zmienia to jednak faktu, że takie reguły istniały i były prawem (nie ma tu znaczenia czy zwyczajowym, czy stanowionym). $\mathrm{Z}$ tego faktu nie wynika moralna ocena ich obowiązywania. Wskazać jednak trzeba, że przywołane ukierunkowanie filozofii prawa przez Harta na empirię nie odpowiada potrzebom praktyki. Nie jest możliwe - na jej gruncie - osądzenie przykładowego ludożercy przez społeczność o innym systemie reguł. Analogicznym przykładem jest problem możliwości osądzenia żołnierzy służących w armii niemieckiej za czasów sprawowania władzy przez Hitlera, którzy wykonywali legalnie wydane rozkazy (umocowane w ówczesnym systemie prawnym Niemiec) w oczywisty sposób godzące w godność człowieka. Teoria Harta nie daje jasnej odpowiedzi na zarysowane pytania. Powinna zatem zostać uzupełniona.

Hart - ilustrując potrzebę uwzględnienia w teorii prawa norm wtórnych - podaje przykład hipotetycznej wspólnoty pierwotnej, w której relacje społeczne porządkowane są wyłącznie przez reguły pierwotne. Wskazuje on na trzy istotne wady takiego społeczeństwa ${ }^{57}$ :

1. niepewność co do treści i zakresu reguł (nie ma pewności, czy uznać daną regułę za obowiązującą);

2. statyczność reguł - w tym sensie, że nie istnieją reguły mówiące o procedurze zmiany już obowiązujących reguł lub wprowadzenia nowych. Przy czym chodzi Hartowi o sztuczne reguły formalne. Ma on bowiem świadomość, że w kulturach pierwotnych zmiany zachodzą niejako naturalnie na drodze długotrwałej, jednolitej praktyki (nie jest to jednak wystarczające);

3. „nieskuteczność rozproszonego nacisku społecznego" 58 .

Przy czym owa nieskuteczność wynika z dwóch elementów:

- braku organów orzekających o tym, czy dany czyn stanowi przekroczenie reguły;

- braku organów wymierzających sankcje.

Hart wskazuje, że brak odpowiednich organów prawnych powoduje niekończące się dyskusje nad tym, czy dana reguła została złamana, czy

57 Ibidem, s. 131-133.

58 Ibidem, s. 133. 
nie. Ponadto wymierzanie sankcji pozostawia kogoś poszkodowanym, co prowadzi na przykład do rozwoju zwyczaju zemsty rodowej. Potrzebna zatem jest autorytatywna władza stwierdzająca, czy prawo zostało naruszone i w razie potrzeby zarządzająca aparatem wymierzania sankcji ${ }^{59}$.

Lekarstwem na wymienione wyżej wady systemów prawa, które nie wykształciły reguł pierwotnych, są, zdaniem Harta, reguły wtórne.

\section{Ad 1}

Niepewność co do treści i zakresu reguł koryguje reguła uznania, która wskazuje, czy dany zespół cech uznany może być za regułę. Mówiąc prościej, reguła ta daje podstawę, aby odpowiedzieć na pytanie, czy coś jest prawem, czy też nie jest. W języku Harta sprowadza się do odpowiedzi na pytanie, czy jej przekroczenie powoduje zastosowanie sankcji - chociażby społecznej (sankcja nie sprowadza się do przemocy). Najprostszą formą zastosowania reguły uznania jest spisanie norm. Co ciekawe, istnieje też bardziej wysublimowana forma, obecna w rozwiniętych systemach prawnych, a odwołująca się do tradycji kultury prawnej. Hart wskazuje bowiem, że jednolita praktyka może stanowić źródło prawa. Przy czym precyzuje, że nie może być ona sprzeczna z ustawą ${ }^{60}$. Warto w tym miejscu przypomnieć, że Hart przyznał w replice na krytykę Dworkina, że błędem było nieuwzględnienie ogólnych zasad obecnych w praktyce prawniczej. Ich wprowadzenie nie jest sprzeczne z całością sytemu Harta (co zostało omówione w podrozdziale 3.1). Należy jednak zauważyć, że dla zachowania spójności logicznej wywodu Harta zasady te nie mogą być sprzeczne z regułą uznania, albowiem nie zostałyby rozpoznane jako prawo. Należy zatem postawić pytanie, czy Hart inaczej rozumie zasady prawa niż Dworkin.

We wspomnianej replice Hart wskazywał, że ogólne zasady prawa również zostają rozpoznane dzięki zastosowaniu reguły uznania ${ }^{61}$. Jest to niezwykle ważne stwierdzenie dla dalszego wywodu. Odnieść je należy do treści poniższego cytatu: „Funkcja reguły uznania polega na określaniu jedynie ogólnych warunków, które muszą spełniać poprawne decyzje prawne w ramach współczesnych systemów prawa (...). Nie odnoszą się one do treści prawa, ale do sposobu i formy tworzenia i recepcji prawa" ${ }^{62}$. Mają one zatem jedynie charakter proceduralny (formalny). Przy takim rozumieniu

\footnotetext{
59 Ibidem.

60 Ibidem, s. 133-134.

61 Ibidem, s. 337.

62 Ibidem, s. 345.
} 
reguły uznania nie ma sprzeczności w rozumieniu zasad przez Dworkina i Harta. W regule uznania mieści się bowiem kompetencja do uznania danej zasady ogólnej za obowiązującą w konkretnym przypadku. Co więcej, Hart podkreśla otwartość reguły uznania. Polega ona na niezupełności systemu prawnego, uzupełnianego każdorazowo przez sędziów ${ }^{63}$. Hart nie wyjaśnia jednak dostatecznie, na czym owo uzupełnienie konkretnie miałoby polegać. Twierdzi, że „z praktycznego punktu widzenia nie ma żadnego znaczenia, czy sędzia (...) tworzy prawo w związku z moralnością (będąc poddanym ograniczeniom nałożonym przez prawo), czy też jest kierowany przez swoje przekonania moralne ku temu, co zostało ujawnione dzięki sprawdzianom moralnym w prawie istniejącym już wcześniej”64.

Pojawia się pytanie, na czym owo ograniczenie nałożone przez prawo ma konkretnie polegać i czy są przypadki, w których sąd moralny ma pierwszeństwo przed normą prawną. Hart unika odpowiedzi na to pytanie. Co więcej, wskazuje, że „teoria prawa winna unikać zaangażowania w sporne teorie filozoficzne dotyczące ogólnego statusu przekonań moralnych oraz winna pozostawić otwartą (...) ogólną kwestię, czy posiadają one to, co Dworkin nazywa obiektywną pozycją" ${ }^{” 5}$. Odpowiedź Harta jest zatem niekonkluzywna. Odnieść ją należy do jego ogólnofilozoficznego nastawienia empirycznego, albowiem w tym momencie wywodu Harta ujawnia się doniosła wada takiego podejścia. Mianowicie, odwołując się jedynie do doświadczenia, można wskazać na to, czym prawo jest, nie można natomiast powiedzieć, czym być powinno, albowiem przyszłość jest poza sferą możliwego doświadczenia, a ponadto łączy ją z teraźniejszością relacja oparta na powinności, nie zaś na przyczynie i skutku. Pewnym wyłomem od powyższej tezy jest pogląd Harta na minimalną treść prawa natury, w którym z faktu czysto doświadczalnego wysuwa on postulat co do treści przyszłego prawa, wychodząc tym samym poza metodę empiryczną - co będzie przedmiotem dalszych rozważań.

Zdaniem Harta prawo winno być otwarte na koncepcje etyczne. Nie znajdziemy jednak w jego filozofii odpowiedzi na pytanie o treść tych koncepcji (poza minimalną treścią prawa natury). Dla Harta istotne jest jedynie to, że wnioski z tych koncepcji staną się prawem dopiero wtedy, gdy podlegać będą pod regułę uznania, a zatem zostaną zapisane w tekście prawnym lub

63 Ibidem, s. 337.

64 Ibidem, s. 339.

65 Ibidem. 
staną się częścią kultury prawnej przez ich długotrwałe stosowanie w praktyce sądowej i obecność w języku użytkowników prawa.

\section{Ad 2}

Lekarstwem na statyczność reguł są, zdaniem Harta, „reguły zmiany”. Ich funkcja polega na nadawaniu kompetencji do ustanawiania i uchylania prawa, czyli do stworzenia i stosowania procedury legislacyjnej ${ }^{66}$. Hart podkreśla, że dzięki tym regułom możliwe jest korzystanie z głównych zalet istnienia sytemu prawnego w postaci na przykład możliwości sporządzania umów, „które organizują życie pod rządami prawa" ${ }^{\text {"7 }}$. Powyższa teza Harta wskazuje zatem, że celem prawa jest porządkowanie życia ludzi. Po analizie koncepcji minimalnej treści prawa natury okaże się, że takiego porządkowania, które zapewnia ludziom przetrwanie (patrz podrozdział 3.5).

\section{Ad 3}

Lekarstwem na nieskuteczność rozproszonego nacisku społecznego są, zdaniem Harta, „reguły orzekania”. Nadają one kompetencje do autorytatywnego orzekania, „czy jakaś reguła pierwotna została naruszona w danym przypadku" ${ }^{\prime 8}$. Reguły te wskazują nie tylko ludzi czy organy, które są uprawnione do takich rozstrzygnięć, ale również procedurę, według której mają postępować w procesie orzekania. Ponadto reguły te tworzą oficjalny scentralizowany system sankcji.

Wszystkie trzy rodzaje reguł wtórnych są oczywiście ze sobą ściśle powiązane i nie mogą samodzielnie spełniać swoich funkcji. Hart wskazuje, że „związek reguł pierwotnych i wtórnych plasuje się w samym centrum sytemu prawa, ale nie jest jego całością" ${ }^{\prime \prime}$. Konieczne są zatem dalsze rozważania. 


\subsection{ZWIĄZEK PRAWA I MORALNOŚCI \\ w FilozofiI Herberta Harta}

Na wstępie niniejszego podrozdziału należy wskazać, że w kulturze anglosaskiej - inaczej niż na gruncie polskiej filozofii - nie funkcjonuje precyzyjne rozróżnienie pomiędzy pojęciami „moralność”70 $\mathrm{i}$ „etyka”. W szczególności nie zawsze słowa „moralność” używa się w rozumieniu przedmiotu etyki. Niemniej wielu filozofów zachowuje klasyczny podział ${ }^{71}$. Hart używa w niektórych miejscach słowa „moralność” tam, gdzie mowa jest o etyce.

Interpretacja związku prawa i moralności w filozofii Harta nie jest rozumiana jednolicie. Wywołała długotrwałe wspomniane polemiki na przykład z Dworkinem czy Fullerem, po czym następowały repliki Harta zarzucające zniekształcenie jego poglądów. Spowodowane jest to tym, że zachowanie spójności logicznej pomiędzy twierdzeniami Harta o systemie prawa stanowionego a jego refleksją czysto filozoficzną wymaga od czytelnika ekwilibrystyki intelektualnej i nie zawsze prowadzi do jednoznacznych rezultatów.

Zdaniem autora niniejszego tekstu, analizując całość poglądów Harta, należy stwierdzić, że pomiędzy nazwą "prawo” a nazwą „moralność” zachodzi relacja krzyżowania się zakresów. Przy czym punktem z konieczności wspólnym dla prawa i moralności jest minimalna treść prawa natury, która wywodzona jest $\mathrm{z}$ celu ludzkiej natury, jakim jest przetrwanie ${ }^{72}$.

Odnosząc się do powyższej tezy, wskazać trzeba, że Hart czyni szereg założeń:

1. istnieje natura ludzka ${ }^{73}$

2. natura ludzka posiada cechy dostępne ludzkiemu poznaniu ${ }^{74}$;

3. natura ludzka jest celowa ${ }^{75}$;

4. celem ludzkiej natury jest przetrwanie człowieka ${ }^{76}$;

70 Moralność rozumiana jest rozmaicie. Dla niektórych jest to pojęcie niedefiniowalne. Na uczelni autora niniejszego tekstu moralność rozumiana jest jako relacja koniecznościowa zachodząca między decyzją człowieka a przyjętym przez niego systemem norm i wartości. Jeśli autor niniejszego tekstu rozumie ją w sposób prawidłowy, to konieczność relacji wynika z jej rozumowego charakteru, a zatem z konieczności logicznej. Zasadnicza trudność życia moralnego sprowadza się do jedności poglądów moralnych i czynów. Trudność ta została najpełniej przedstawiona w koncepcji trwogi Sartre’a.

71 Zob. P. Vardy, P. Grosch, Etyka. Poglądy i problemy, Poznań 2010, s. 14.

72 H. L. A. Hart, Pojęcie prawa, s. 258-261.

73 Ibidem, s. 261.

74 Ibidem.

75 Ibidem, s. 260-261.

76 Ibidem. 
5. człowiek poznaje cel swej natury poprzez analizę struktury myśli i języka ${ }^{77}$;

6. zasadna jest realizacja celu wyznaczonego przez naturę;

7. istnieją elementy koniecznie wspólne dla prawa i moralności oraz elementy, gdzie takiego koniecznego związku nie $\mathrm{ma}^{78}$.

Wskazać należy, że teza o istnieniu ludzkiej natury stanowi silne założenie metafizyczne i nijak się ma do poglądów Harta na temat oczyszczenia teorii prawa $z$ wpływów metafizyki. Dla przykładu można powiedzieć, że dla Sartre’a nie istnieje coś takiego jak natura ludzka. „Ja” jest wynikiem absolutnie wolnej kreacji. Wyróżnia on jednak tzw. kondycje (fakt przyjścia na świat, konieczność śmierci i pracy w celu podtrzymania życia). Człowiek ustosunkowuje się do nich w sposób całkowicie wolny.

Ponadto z samej tezy metafizycznej o istnieniu natury ludzkiej nie wynika, że jest ona poznawalna, a tym bardziej, że ma charakter teleologiczny. Człowieka można rozumieć, na przykład, jako twór doboru naturalnego, a zatem gry losowych mutacji. Przy czym cechy konstytuujące twory natury istnieją nie ze względu na cel, ale na użyteczność dla życia w danym środowisku.

Autor nie rozstrzyga w niniejszym tekście wskazanych wyżej zagadnień $^{79}$. Powyższy komentarz służy jedynie wykazaniu, że Hart przyjmuje za oczywiste tezy, które w żadnym razie za takie uznane być nie mogą. Nie wyjaśniają one bowiem filozoficznych założeń uzasadniających przyjęty przez niego punkt widzenia. W szczególności nie zdołał uniknąć - jak sam ją nazywa - „ciemnej metafizyki”"80. Bez odwołania do metafizyki wszelkie

77 Ibidem, s. 260.

78 Ibidem, s. 272 in fine oraz s. 359.

$79 \mathrm{Na}$ istnienie natury człowieka - a co więcej, na jej społeczny (lub stadny) charakter - wskazuje argument wywodzony od Arystotelesa i potwierdzony przez współczesną psychologię. Mianowicie, by stać się w pełni człowiekiem, należy nabyć kompetencje językowe, a to możliwe jest wyłącznie w społeczeństwie. Zdaniem autora niniejszego tekstu, zasadne jest zatem mówienie o naturze ludzkiej, a nie tylko o kondycjach (jak chciał na przykład Sartre). Kontrowersje budzi jednak to, czy natura ludzka jest społeczna, czy jedynie stadna. Społeczna - według szkoły lubelskiej - miałaby przejawiać się w działaniu w sposób wolny i świadomy, przy czym wolność polegałaby w tym ujęciu na realizacji własnej potencjalności, a zatem na realizacji wskazań natury. Tak więc natura jest społeczna, jeśli realizuje swoja naturę - co jest błędnym kołem. Zdaniem autora niniejszego tekstu, problem wykazania różnicy pomiędzy naturą ludzką a zwierzęcą jest jednym z głównych problemów filozofii. Przy czym tomizm nie podaje w tym zakresie wystarczających argumentów. W szczególności podważa się brak umiejętności racjonalnego posługiwania się mową i narzędziami przez ssaki naczelne. Z badań empirycznych wynika, że rozwój niektórych ssaków naczelnych dorównuje rozwojowi trzyletniego dziecka, co uzasadnia próby zrewidowania pojęcia osoby (ewentualnie podważenie kryteriów oceny rozwoju). W uproszczeniu - dyskusja sprowadza się do zasadności powoływania się na potencjalność przy próbie definiowania osoby, a najpełniej zobrazowana jest współcześnie przez debaty Petera Singera z Charlesem Camosy, który za Tomaszem z Akwinu podkreśla rolę złożenia bytu przygodnego z istoty i aktualizującego ją istnienia. Dyskusja jest wciąż otwarta.

80 H. L. A. Hart, Pojęcie prawa, s. 120. 
uzasadnienia filozoficzne wydają się niepełne, a co za tym idzie - podatne na krytykę.

Hart twierdzi, że z empirycznego badania struktur języka (również z perspektywy jego użytkownika) wynika, że celem naszej natury jest przetrwanie, a co więcej, że należy tak wskazany cel realizować poprzez odpowiednie działania legislacyjne. Trzeba zadać pytanie, czy Hart rozumie przetrwanie jedynie jako wegetację, czy też jako życie rozumiane szerzej niż czysto biologicznie. Jeśli jako wegetację, to doświadczenie obala tę teorię, albowiem istnieje bardzo wiele przypadków, w których ludzie cenią sobie wyżej inne wartości od długości życia. Autor niniejszego tekstu nie ma tu na myśli tylko takich wartości jak wolność czy honor, ale również przyjemność. Z prostej obserwacji wynika, że wielu ludzi wyżej ceni sobie przygodny seks czy niezdrowe jedzenie od długości życia. Jeśli natomiast Hart ma na myśli przetrwanie w sensie życia o określonych walorach, na przykład życie godne, to musiałby je zdefiniować, co bez stworzenia koncepcji etycznej nie jest możliwe.

W odniesieniu do wywodzenia przez Harta celu ludzkiej natury z analizy języka wskazać trzeba na kolejną trudność. Mianowicie, dla prawdziwości jego tezy należałoby założyć, że w języku zakodowana jest normatywność. Zbliżałoby to jego poglądy do teorii racjonalności komunikacyjnej Habermasa. Pamiętać jednak trzeba, że teza o normatywności ukrytej w języku rodzi szereg pytań, których Hart nawet nie formułuje (na przykład o pojęcie rozumu pozwalającego ową normatywność odkryć). W literaturze przedmiotu wskazuje się, że istnieją interpretacje myśli Harta jako zbliżonej do hermeneutyki ${ }^{81}$.

Odnosząc się do punktu 7. (założenie o istnieniu zakresu koniecznie wspólnego dla prawa i moralności), należy wskazać, że Hart wprost podaje taką interpretację minimalnej treści prawa natury, która uniemożliwia wyprowadzenie innego wniosku niż ten, że minimalna treść prawa natury stanowi minimum, w jakim prawo musi pokrywać się z moralnością ${ }^{82}$. W innych jednak miejscach twierdzi on, że nie istnieje konieczny (również pojęciowy) związek między prawem a moralnością ${ }^{83}$. Jedyną możliwością interpretacji, która nie sprowadzałaby się do wykazania sprzeczności w poglądach Harta, jest przyjęcie, że związki te nie są konieczne dla identyfikacji normy jako normy prawnej (poprzez regułę uznania) z wyjątkiem niewielkiego obszaru, który

81 M. Zirk-Sadowski, Wprowadzenie do filozofii prawa, s. 197.

82 H. L. A. Hart, Pojęcie prawa, s. 272.

83 Ibidem, s. 359 .

Mariusz Leleno-Czarnak - Aktualność filozofil prawa Herberta Harta jako krytyki pierwotnego pozytywizmu prawnego... 
Hart nazywa minimalną treścią prawa natury (w tym kontekście należałoby mówić o minimalnym zakresie, a nie o treści). Przy czym Hart wskazuje w odniesieniu do norm spoza zakresu minimum prawa natury - że co prawda związki z moralnością nie są koniecznie (dla identyfikacji normy jako prawa), ale faktycznie istnieją, a nawet sprzyjają stabilności sytemu prawnego ${ }^{84}$.

Na marginesie należy zauważyć, że Hart w jednej z publikacji wprowadza porzucony potem podział na formal values i material values. Te pierwsze miałyby stanowić wartości niezbędne dla przeżycia danej społeczności, te drugie zaś są odpowiednikiem wartości w klasycznym rozumieniu ${ }^{85}$. Pomysł ten prawdopodobnie został podyktowany oczywistym dla prawników podziałem na prawo materialne i formalne. Nie należy go jednak przenosić na grunt etyki. Przede wszystkim wartości sprzyjające przetrwaniu społeczności mogą być sprzeczne $\mathrm{z}$ wartościami w klasycznym sensie. W takim przypadku należałoby się odwołać do trzeciej kategorii nadrzędnych wartości, co komplikuje pierwotnie założony podział. Ponadto o przeżyciu grupy społecznej nie decydują jedynie normy formalne, ale także materialne.

Analizując związki prawa i moralności, należy pamiętać o otwartości reguł wtórnych, w szczególności reguły uznania (zob. podrozdział 3.3). Reguły są otwarte na krytykę ze strony stanowisk etycznych. Sam Hart twierdzi: „Moja teoria (...) dopuszcza, jako kryteria prawa, nie tylko »czyste fakty«, ale i wartości” ${ }^{” 6}$. Niemniej kryterium wartości stosowane musi być w sposób konieczny jedynie w zakresie objętym minimalną treścią prawa natury. W pozostałym może być stosowane, ale nie musi, przy czym jego stosowanie jest pożądane $\mathrm{z}$ uwagi na stabilność systemu.

Rozważając zagadnienie prawa i moralności, warto pochylić się nad sposobem rozumienia przez Harta moralności, a ściśle rzecz ujmując - jej formalnych wyróżników ${ }^{87}$. Jego zdaniem wskazanie na formalne atrybuty moralności pozwala na odróżnienie norm moralnych od norm prawnych i „innych postaci reguł społecznych"88 (Hart wspomina w tym kontekście o normach zwyczajowych, nie wyróżnia jednak na przykład norm religijnych). Co ważne, formalny charakter tych atrybutów pozwala - jego zdaniem „obejść (...) filozoficzne trudności” ${ }^{89}$ związane z definiowaniem wartości, m.in. $\mathrm{z}$ ich statusem ontycznym.

84 Ibidem, s. 275.

85 H. L. A. Hart, Law, Liberty and Morality, Oxford 1982, s. 71.

86 H. L. A. Hart, Pojęcie prawa, s. 332.

87 Ibidem, s. 245.

88 Ibidem, s. 235.

89 Ibidem, s. 229. 
Wskazać zatem należy, że rozumienie przez Harta normy moralnej budzi zastrzeżenia, a dalsza część niniejszego podrozdziału ma znaczenie jedynie ukazujące braki owej koncepcji.

Hart rozpoczyna swój wywód od zreferowania - jego zdaniem - błędnego poglądu na rozdział prawa i moralności. Nie wymienia nazwiska Kanta, ale niewątpliwie odnosi się do jego systemu, pisząc o najbardziej znanej próbie „uchwycenia istotnej różnicy pomiędzy prawem i moralnością"90. Interpretacja Harta jest poprawna w odniesieniu do myśli Kanta, ale zbyt powierzchowna. Hart nie bierze też pod uwagę dalszego rozwój filozofii. Wskazuje na istnienie poglądu, według którego „reguły prawne wymagają jedynie »zewnętrznego« zachowania się, a są niezależne od motywów, intencji i innych »wewnętrznych« okoliczności towarzyszących postępowaniu, moralność, przeciwnie, nie wymaga żadnego specyficznego działania zewnętrznego, a tylko dobrej woli czy właściwych zamiarów i motywów" ${ }^{\prime 1}$.

Na gruncie kantyzmu o moralności czynu faktycznie decyduje motyw (maksyma woli). Koncepcja ta stanowiła jednak inspirację dla rozważań min. Sartre'a ${ }^{92}$, według którego ocena moralna wymaga czynu ${ }^{93}$. Odwołując się do powszechnie znanego przykładu Kanta (opisującego sytuację, w której ratujący tonące dziecko postępuje moralnie nie z uwagi na samo działanie, ale z uwagi na motyw owego działania), w bliskich autorowi koncepcjach filozoficznych wskazuje się, że wątpliwości budzi twierdzenie Kanta, iż o ocenie moralnej ratującego decyduje wyłącznie motyw. Jeśli bowiem motyw ma być autentyczny, musi prowadzić do czynu (ściślej mówiąc, autentyczność implikuje wybór wyrażony w czynie) ${ }^{94}$. Jak ów ratujący miałby posiadać szczery motyw uratowania tonącego dziecka, a nie dokonać wyboru działania bądź zaniechania (ze względu na inny motyw)? Szczery motyw zawsze prowadzić winien do czynu

90 Ibidem, s. 234.

91 Ibidem.

92 Należy pamiętać, że dla Kanta człowiek jako homo noumenon jest całkowicie wolny i w tym aspekcie jego wola jest absolutna. Teza ta zainspirowała dwóch filozofów uważających się za kantystów - Fichtego, który uważał, że najpierw jesteśmy czynem, potem dopiero bytem, oraz Schopenhauera, u którego nienasycalna wola urosła do rangi zasady świata. Sartre niewątpliwie jest kontynuatorem tego sposobu myślenia. Z tego powodu autor niniejszego tekstu traktuje go jako kantystę oraz potencjalne źródło reinterpretacji myśli Kanta.

93 W tym sensie, że oceniać zarówno własne postępowanie, jak i postępowanie innych można jedynie oceniając wybór. Przy czym wybór jest nam wiadomy dopiero w momencie czynu. Według Sartre’a człowieka nie determinuje ani przeszłość (motyw postępowania), ani przyszłość (ja idealne). Ów brak determinacji nazwał Sartre podwójnie nicościującą rolą świadomości. Człowiek jest zmuszony do nieustannego aktualizowania siebie. Przy czym niemożliwe jest według Sartre’a poszukiwanie wytycznych postępowania poprzez analizę bytu. Koncepcja Sartre’a zbudowana jest na ontologii prowadzącej do wniosku, że nie jest możliwym uzasadnienie bytu, co stawia jego koncepcję w opozycji do klasycznej metafizyki.

94 Konieczność nieustannej aktualizacji siebie implikuje konieczność dokonywania nieustannych wyborów, które przejawiają się w czynie. 
(działania bądź zaniechania). Pomiędzy motywem a czynem istnieje rozdarcie, które Sartre nazwał trwogą. Jest to obawa przed rozdźwiękiem między motywem a jego urzeczywistnieniem ${ }^{95}$. O ocenie moralnej czynu decyduje zatem wybór. Podobnie jak Kant odnośnie do motywu, tak Sartre odnośnie do wyboru postuluje, aby dokonywać ich w taki sposób, by wola nasza nadawała im walor powszechności, co ukazuje poniższy cytat: „W istocie każdy nasz czyn, poprzez który stwarzamy w sobie człowieka według własnej woli, pociąga jednocześnie za sobą stworzenie wzoru człowieka takiego, jakim według nas być powinien. Wybrać byt ten lub inny, to znaczy afirmować jednocześnie wartość tego, co wybieramy (...). W ten sposób nasza odpowiedzialność jest większa, niż mogłaby nam się zdawać, gdyż angażuje ona całą ludzkośćc”.

Teza o rozdziale prawa i moralności w koncepcji Kanta polega na twierdzeniu, że obserwator nie jest zdolny do poznania motywu, jakim kieruje się inny. Moralność jest relacją człowieka do samego siebie. Relacje międzyludzkie reguluje prawo, którego istnienie jest warunkiem możliwości dokonania czynu moralnego. Prawo zapewnia bowiem każdemu tę samą sferę wolności. Zaś o czynie moralnym, dobrym bądź nie, możemy mówić jedynie w warunkach wolnego wyboru. O rozdziale prawa i moralności decydują zatem ograniczenia sfery poznawczej człowieka - o czym Hart nie wspomina. By czyn był moralny, mam chcieć, by mógł on stać się powszechnym prawem ${ }^{97}$. Warto podkreślić, że w tezie tej zawarty jest element konieczności logicznej. Jeśli rozważyć mam np. zasadność dokonania kradzieży, to muszę pomyśleć, co byłoby, gdyby zabór mienia stał się powszechnym prawem. Jeśli zabór mienia miałby stać się powszechnym prawem, niemożliwe byłoby prawo własności a to jest wewnętrznie sprzeczne. By uniknąć tej sprzeczności, powstrzymuję się od kradzieży, a zatem dopuszczam się zaniechania. Analogiczny wywód można chociażby przeprowadzić co do konieczności przestrzegania umów (jeśli powszechne byłoby ich nieprzestrzeganie, wkrótce umowy przestałyby istnieć, a to jest sprzeczne, albowiem nie sposób pogodzić zdań: „umów nie nienależny przestrzegać” oraz „nie ma czegoś takiego jak umowa”).

Ponadto, co zostało już zasugerowane, normy prawa nie są - jak chce Hart - niezależne od motywów postępowania. Stanowią formalne ramy, w których owe motywy mogą się spełniać. Nie są zatem niezależne, ale stanowią konieczny warunek urzeczywistnienia indywidualnych motywów.

95 J. P. Sartre, Problem bytu i nicości. Egzystencjalizm jest humanizmem, Warszawa 2001, s. 96.

96 J. P. Sartre, Egzystencjalizm jest humanizmem, Warszawa 1998, s. 29-30. Ten sam esej znajduje się także w publikacji wymienionej w poprzednim przypisie. Podaję przypis do innej publikacji, ponieważ jest to dla mnie wygodniejsze z uwagi na posiadane fotokopie.

97 Zob. I. Kant, Uzasadnienie metafizyki moralności, Kęty 2001, s. 38. 
Należy dodać, że rozdział prawa i moralności u Kanta nie ma charakteru absolutnego, jak na przykład u Kelsena. Uzasadnieniem zarówno prawa, jak i moralności jest rozum praktyczny, którego celem jest wieczny pokój (celem rozumu teoretycznego jest poznanie rzeczy samych w sobie). Prawo i moralność łączy zatem cel. Niemniej wskazuje się, że źródłem normatywności jest dla Kanta rozumna wola, czyli nie cel $^{98}$ jako taki ${ }^{99}$.

Niewątpliwie wola jest również źródłem normatywności dla Sartre’a. Pytanie brzmi, na ile jest ona dla Sartre'a subiektywna, a na ile wbudowane są w nią elementy racjonalne. Pomimo że synteza poglądów Kanta i Sartre’a wydaje się być zagadnieniem interesującym, wymaga przeprowadzenia gruntownych badań i wykracza poza przedmiot niniejszej publikacji. Istotne jest to, że dla Sartre’a prawo nie stanowi warunku moralności. Człowiek jest bowiem wolny w każdej sytuacji zarówno prawnej, jak i faktycznej. Sartre nie zajmował się szerzej filozofią prawa, ale jego poglądy mają istotne znaczenie. Wydaje się bowiem, że ich adaptacja pozwala na utrzymanie tezy o rozdziale prawa i moralności, przy jednoczesnym wskazaniu, że o wartości moralnej czynu decyduje nie motyw, ale wybór - a zatem czyn. Prawo bowiem - jako czynnik porządkujący - musi mieć inne źródło niż wola aktualizowana każdorazowo przez podmiot dokonujący wyboru.

98 Por. R. Moń, Warto czy należy?, Warszawa 2011, s. 88.

Kantowskie pojęcie woli jest specyficzne, posiada bowiem czysto aprioryczne wyznaczniki. Kant pisze: „zasadą naczelną moralności jest czyste, a priori kierujące wolą prawo” I. Kant, Krytyka praktycznego rozumu, Kęty 2002, s. 74.

Kant ma tu na myśli prawo moralne, które jako efekt czystego rozumu (oderwanego od doświadczenia) jest wyznacznikiem pojęcia dobra i zła.

Dla Kanta: „Dobra wola nie jest dobra ze względu na swoje dzieła i skutki ani ze względu na swoją zdolność do osiągnięcia jakiegoś zamierzonego celu, lecz jedynie przez chcenie” I. Kant, Uzasadnienie metafizyki moralności, s. 12.

Postępować dobrze to dla Kanta postępować bez względu na skutki, ale dlatego, że taka jest bezwzględna powinność. Jest to o tyle istotne, że Hart należy do tradycji etycznej z przeciwnego bieguna myśli. Mianowicie dla niego o wartości moralnej czynu decyduje rezultat działania, nie zaś czysta, rozumowo konieczna powinność.

99 Niemniej rozważając człowieka jako homo phaenomenon, cel może być rozumiany jako pierwotny w stosunku do powinności. Kant pisze: „Rozum jako władza zasad naczelnych wyznacza zainteresowanie wszystkim siłom umysłu, a swój samemu sobie. Zainteresowanie jego spekulatywnego użycia polega na poznaniu przedmiotu aż do najwyższych naczelnych zasad apriorycznych; zainteresowanie praktycznego użycia polega na wyznaczeniu kierunku woli ze względu na ostateczny i zupełny cel” I. Kant, Krytyka praktycznego rozumu, Kęty 2002, s. 123.

W innym miejscu Kant utożsamia wolę z praktyczną funkcją czystego rozumu: „Wola jest zatem władzą pożądania, rozpatrywaną nie tyle w odniesieniu do działania (tak jak zdolność wyboru), ile raczej w odniesieniu do postawy determinującej zdolność wyboru do działania; ona sama nie jest więc właściwie poprzedzana przez żadną podstawę determinującą, lecz jest samym praktycznym rozumem, o ile ten może determinować zdolność wyboru” I. Kant, Metafizyczne podstawy nauki prawa, Kęty 2006, s. 26.

Wskazanie precyzyjnego rozróżnienia pomiędzy prawem moralnym, rozumem praktycznym a wolą wymagałoby przeprowadzenia badań znacznie wykraczających poza przedmiot niniejszego tekstu. Na tym etapie wydaje się, że są to pojęcia, jeśli nie tożsame, to zbliżone znaczeniowo. 
Powyższy wywód miał na celu wskazanie, że błędem jest zdawkowa krytyka Kantowskiego sposobu pojmowania prawa i moralności. Po pierwsze, Hart nie zauważa, że w koncepcji tej rozdział prawa i moralności nie jest absolutny. Po drugie, nie widzi możliwości modyfikacji Kantowskiej tezy o rozdziale prawa i moralności.

Hart podaje cztery wyróżniki normy moralnej:

1. Doniosłość - polega ona na poświęceniu interesu osobistego interesowi społecznemu oraz na „poważnych formach presji społecznej”"100;

2. Oporność na świadome zmiany - w tym sensie, że zmiany norm prawnych dokonują się w daleko mniej skomplikowany sposób i znacznie szybciej niż normy prawne ${ }^{101}$;

3. Dobrowolny charakter przekroczeń moralnych - w tym sensie, że zdaniem Harta od odpowiedzialności moralnej można uchylić się z uwagi na stronę podmiotową czynu, a w przypadku normy prawnej możliwość takiego uchylenia jest znacznie ograniczona ${ }^{102}$;

4. Forma presji moralnej - w przypadku moralności ma ona źródło $\mathrm{w}$ sumieniu i poczuciu winy ${ }^{103}$.

\section{Ad 1}

Hart, analizując pojęcie normy moralnej, powołuje się na powszechną intuicję. Normy moralne są bowiem postrzegane jako bardziej doniosłe niż normy prawne - co nie oznacza, że niektóre normy prawne nie mają takiego charakteru. Dla wyróżnienia normy moralnej konieczne jest spełnienie pozostałych trzech warunków. Wątpliwości budzi natomiast kryterium doniosłości. Hart nie uzasadnia w dostateczny sposób, czemu, postępując moralnie, poświęcamy własny interes (a zatem doniosłość norm moralnych jest większa). W wielu koncepcjach etycznych postępowanie zgodne z nakazem jest realizacją interesu jednostki, na przykład prowadzi do zbawienia lub urzeczywistnia wolności.

Wątpliwości budzi również stwierdzenie, że formy społecznej presji za przekroczenie normy moralnej są „poważniejsze” niż za przekroczenie normy prawnej. Należy wziąć pod uwagę fakt, że z przekroczeniem niektórych norm prawa karnego związana jest kara pozbawienia wolności, która wykonywana jest w warunkach o silniejszej lub jednakowo „poważnej” presji społecznej niż przekroczenie normy obyczajowej. Rzadko bowiem

100 H. L. A. Hart, Pojęcie prawa, s. 236.

101 Ibidem, s. 238-239.

102 Ibidem, s. 241-243.

103 Ibidem, s. 243-244. 
w warunkach wolnościowych zdarza się pozbawianie człowieka przymiotu osoby i traktowanie go jak frajera lub cwela, co w więzieniu ma charakter powszechny ${ }^{104}$. Co ciekawe, owa presja ma daleko bardziej niszczące skutki dla ludzi, którzy zinternalizowali powszechnie przyjęte zasady etyczne.

\section{Ad 2}

Wątpliwym jest twierdzenie, że norma prawa stanowionego może być łatwiej zmieniona niż norma moralna. Dla wielu norm prawnych jest to twierdzenie prawdziwe. Wiele jednak norm obowiązującego dziś prawa stanowionego ma zbliżoną treść do norm prawa rzymskiego (patrz podrozdział 2.1). Doświadczenie wskazuje zatem, że nie podlegają one szybkim rewolucyjnym zmianom, ale ulegają podobnej ewolucji co i normy moralne.

Ponadto z repliki Harta na zarzuty Dworkina wynika, że akceptuje on tezę, iż w skład norm prawnych wchodzą zasady prawa, a nie tylko reguły (patrz podrozdział 3.1). Trudno sobie wyobrazić, by na przykład, zasada lex retro non agit (i dziesiątki innych) ulegały szybszej ewolucji niż normy moralne. Doświadczenie wskazuje, że jest odwrotnie. Za przykład niech posłuży rewolucja seksualna i zmiana w postrzeganiu seksu przedmałżeńskiego oraz koncepcji małżeństwa jako takiego, czy zmiana w ocenie homoseksualizmu, z którą mamy obecnie do czynienia.

\section{Ad 3}

Hart wskazuje, że „odpowiedzialność prawna nie jest koniecznie wyłączona przez dowód, że osoba oskarżona nie mogła działać zgodnie z przepisem prawnym, który naruszyła. Odwrotnie jest w przypadku moralności”105. Użycie słowa „oskarżony” wskazuje, że Hart ma na myśli prawo karne nie zaś cywilne. Na gruncie polskiego prawa karnego teza ta jest absurdalna z uwagi na treść art. $1 \$ 3$ Kodeksu karnego: „Nie popełnia przestępstwa sprawca czynu zabronionego, jeśli nie można mu przypisać winy w czasie czynu”106. Po pierwsze, ,zachowanie się człowieka, by mogło być uznane za czyn w rozumieniu prawa karnego, musi być zewnętrznym zachowaniem

104 Presja subkultury więziennej rozpatrywana pobieżnie wydaje się być elementem presji wywieranej za przekroczenie normy zwyczajowej, nie zaś prawnej. Głębsza jednak analiza wskazuje, że normy subkultury więziennej są wykorzystywane przez służbę więzienną (ułatwiają zachowanie porządku), a także stanowią znaczący motyw, jakim kierują się oskarżeni w toku współpracy z policją i prokuratorem. Zatem jest to sankcja na tyle nierozerwalnie związana z sankcją za przekroczenie normy prawnej (skutkującej osadzeniem w zakładzie karnym), że byłoby hipokryzją nie łączyć jej z sankcją karną. Ku tej tezie skłaniają się bardziej psychologowie penitencjarni. Nauka prawa wydaje się w tym zakresie pozostawać w strefie wygodnej ignorancji.

105 H. L. A. Hart, Pojęcie prawa, s. 242.

106 Tekst jednolity: Dz.U. 2020 poz. 1444. 
się zależnym od woli człowieka, musi być sterowane jego wolą"107, a zatem zachowanie w wyniku przymusu bezwzględnego (vis absoluta) nie mieści się w definicji czynu - na przykład nie jest czynem niedopełnienie obowiązków przez dróżnika, jeśli był on związany. Po drugie, jeśli zachowanie jest czynem, to musi być zawinione. Wina zaś może być umyślna bądź nieumyślna. Czyn $\mathrm{z}$ winy umyślnej może być popełniony w zamiarze bezpośrednim albo ewentualnym. Czyn z winy nieumyślnej przez lekkomyślność lub niedbalstwo ${ }^{108}$. Dla klarowności wywodu wystarczy omówić „najsłabszą” formę winy: niedbalstwo. Polega ono na tym, że „sprawca możliwości popełnienia czynu zabronionego nie przewiduje, chociaż może ją przewidzieć (...) zarzucamy sprawcy, że nie wykorzystał swych możliwości intelektualnych"109. Dla przypisania sprawcy winy nieumyślnej w postaci niedbalstwa potrzebne jest naruszenie zasad ostrożności. Naruszenie to ma pozostawać w adekwatnym związku przyczynowym z czynem zabronionym. Ponadto sprawca musi mieć możliwość przewidzenia, że jego czyn wypełni znamiona czynu zabronionego ${ }^{110}$. Zatem na gruncie polskiego prawa karnego cytowana wyżej teza Harta jest fałszywa.

Na gruncie etyki problem można rozstrzygnąć rozmaicie. Najprostszym jednak przełożeniem koncepcji niedbalstwa na język filozofii będzie twierdzenie, że człowiek, który nie postępuje rozumnie, chociaż ma ku temu możliwości, a zachowaniem swym narusza normy postępowania danej społeczności (nie ma tu znaczenia czy intersubiektywne, czy obiektywne), powodując swym działaniem negatywne skutki, postępuje wbrew normom moralnym. Warto zauważyć zbieżność dokonań etyki klasycznej z rozumieniem winy w prawie karnym. Teza ta nie powinna nikogo dziwić, albowiem koncepcja winy ma swe korzenie w myśli Arystotelesa. Te same fragmenty inspirowały etyków, jak i jurystów. Wskazać należy przede wszystkim ósmy punkt V księgi Etyki nikomachejskiej: „Czyn jest sprawiedliwy ${ }^{111}$ bądź niesprawiedliwy, gdy został dokonany na podstawie postanowienia"112.

107 L. Gardocki, Prawo karne, Warszawa 2005, s. 48.

108 Zob. art. $9 \$ 1$ i art. $9 \$ 2$ Kodeksu karnego (tekst jednolity: Dz.U. 2020 poz. 1444).

109 L. Gardocki, Prawo karne, s. 82.

110 Zob. ibidem, s. 82-83.

111 Jednym ze znaczeń słowa „sprawiedliwy” jest dla Arystotelesa zgodność z prawem (nie należy jednak zapominać o jego koncepcji prawości, czyli możliwości odejścia od formalizmu normy prawnej). W najbardziej ogólnym sensie sprawiedliwość to dla Arystotelesa cnota społeczna polegająca na trwałej dyspozycji, dzięki której jesteśmy zdolni do czynów sprawiedliwych. Trudno jednak zarzucać twórcy logiki błędne koło. W toku dalszego wywodu Arystoteles definiuje sprawiedliwość rozdzielczą i wyrównującą. Niemniej jego definicja sprawiedliwości w znaczeniu ogólnym pozostawia niedosyt. Niewątpliwie była jednak inspiracją dla definicji Ulpiana (constans et perpetua voluntas ius suum cuique tribuere - stała wola świadczenia każdemu tego, co mu się należy). Ta z kolei została zaadaptowana przez Tomasza z Akwinu. 112 Arystoteles, Etyka nikomachejska, w: Arystoteles, Dzieła wszystkie, t. V, Warszawa 2002, s. 183-185. 
Nie należy wykluczać, że próba wskazania różnic pomiędzy normą prawa karnego a normą moralną może opierać się na kryterium warunków przypisania czy uniknięcia odpowiedzialności. Koncepcja taka musiałaby być jednak bardziej wysublimowana od twierdzeń Harta.

Jego rozważania mają jednak pewną wartość na gruncie prawa cywilnego. Tam faktycznie obowiązują normy, które pozwalają od pozwanego dochodzić roszczeń na zasadzie nie winy, ale ryzyka. Są to jednak sytuacje zupełnie wyjątkowe. Pozwany nie może uchylić się wtedy od odpowiedzialności, powołując się na to, że nie ponosi winy. Na zasadzie ryzyka odpowiada na przykład podmiot prowadzący na własny rachunek przedsiębiorstwo lub zakład wprawiany w ruch za pomocą sił przyrody, takich jak gaz, para, elektryczność. Przy czym nie odpowiada, jeśli szkoda nastąpiła w wyniku działania siły wyższej (vis maior) lub wyłącznie z winy poszkodowanego lub osoby trzeciej, za którą nie ponosi on odpowiedzialności ${ }^{113}$.

W zupełnie wyjątkowych przypadkach polskie prawo cywilne zna także odpowiedzialność na zasadzie słuszności (na przykład osoba pogryziona przez psa może dochodzić roszczeń od - mówiąc bardzo nieprecyzyjnie jego właściciela, chociażby nie ponosił on winy. Przy czym przemawiać mają za tym okoliczności, zwłaszcza porównanie sytuacji majątkowej powoda i pozwanego oraz zasady współżycia społecznego ${ }^{114}$. Dla oceny poglądów Harta ma to jednak znaczenie marginalne.

\section{Ad 4}

Używając terminów współczesnej socjologii, Hart wskazuje na to, że typową sankcją za przekroczenie norm moralnych jest sankcja rozsiana ${ }^{115}$, zaś za przekroczenie norm prawnych - sankcja zinstytucjonalizowana. Ta pierwsze polega na zróżnicowanych formach presji społecznej, druga na zaangażowaniu organów państwa.

Z powyższym twierdzeniem Harta należy się zgodzić, mając jednak na uwadze fakt, że prawidłowe ustawodawstwo zmierza do tego, by $\mathrm{z}$ jednej strony to, co jest przedmiotem sankcji rozsianej (a jest pożądane przez ustawodawcę), włączyć w system prawny, z drugiej zaś wpływać za pomocą

113 Zob. art. $435 \$ 1$ Kodeksu cywilnego (tekst jednolity: Dz.U. 2019 poz. 1145 z późn. zm.).

114 Zob. art. $431 \S 2$ w zw. z art. $431 \S 1$ Kodeksu cywilnego (tekst jednolity: Dz.U. 2019 poz. 1145 z późn. zm.).

115 Hart nie używa pojęcia „sankcja rozsiana”. Jest to pojęcie powszechnie używane w socjologii prawa oraz w socjologii ogólnej, które w pełni oddaje treść poglądów Harta. Sankcja ta jest przeciwstawiana sankcji zinstytucjonalizowanej (formalnej) i jest jedną z form kontroli społecznej. Polega na spontanicznym stosowaniu nieformalnego nacisku przez członków tej samej grupy społecznej. Sankcja rozsiana bywa nazywana sankcją rozproszoną. Por. P. Sztompka, Socjologia. Analiza społeczeństwa, Warszawa 2007, s. 411. 
modyfikacji systemu prawnego na zmiany w funkcjonowaniu sankcji rozsianej w pożądanym z punktu widzenia ustawodawcy kierunku. Zajmuje się tym socjologia prawa. Uprawiana na UW ma swe korzenie w poglądach Leona Petrażyckiego, a zatem osadzona jest w myśli filozoficznej. Sprawą odmienną jest to, na ile polski ustawodawca korzysta ze wskazań socjologii prawa.

\subsection{KONCEPCJA MINIMALNEJ TREŚCI PRAWA NATURY}

Jak zostało wykazane w podrozdziale 3.4, minimalna treść prawa natury jest to ten obszar prawa i moralności, w którym z konieczności ich zakresy są wspólne. W niniejszym podrozdziale przedstawione zostaną postulaty co do jego treści.

Treść tę implikuje założenie wskazujące, że zarówno prawo, jak i moralność realizować muszą chociażby ten jeden minimalny cel zwany przez Harta przetrwaniem ${ }^{116}$. Jak zostało wspomniane, nie jest to - wbrew twierdzeniom Harta - pojęcie jasne ani oczywiste. Wskazuje on, że bez realizacji wspomnianego założenia, ludzie nie mieliby powodu do dobrowolnego podporządkowania się prawu ${ }^{117}$.

Wytycznymi dla treści prawa natury są - dla Harta - następujące, uznane przez niego, fakty:

1. ludzka słabośćn ${ }^{118}$,

2. przybliżona równość ludzi ${ }^{19}$,

3. ograniczony altruizm ${ }^{120}$,

4. ograniczona ilość dostępnych zasobów ${ }^{121}$,

5. ograniczenia człowieka w sferze rozumienia i siły woli ${ }^{122}$.

116 H. L. A. Hart, Pojęcie prawa, s. 261.

117 Ibidem, s. 261-262.

118 Ibidem, s. 262.

119 Ibidem.

120 Ibidem, s. 264.

121 Ibidem, s. 265.

122 Ibidem, s. 266. 


\section{Ad 1}

Słabość człowieka powoduje, zdaniem Harta, wprowadzenie do sytemu prawa norm ograniczających użycie przemocy. Jego zdaniem są one podstawowe w tym rozumieniu, że bez nich istnienie pozostałych byłoby wątpliwe.

\section{Ad 2}

Przybliżona równość ludzi jest związana z naszą słabością. Hart wskazuje, że ludzie różnią się znacznie pod wieloma względami. Nie są to jednak różnice na tyle znaczne, by jednostka bez pomocy innych mogła na stałe zdominować innego człowieka. „Nawet, ci którzy są najsilniejsi, muszą od czasu do czasu spać, a gdy śpią, tracą swą przewagę"123. Implikuje to konieczność kompromisu polegającego na powstrzymywaniu się od przemocy.

$\mathrm{Na}$ marginesie należy dodać, że Hart nie używa terminu „umowa społeczna”. Jego wywód jest jednak bez wątpienia inspirowany koncepcją Hobbesa ${ }^{124}$, choć nie zgadza się z jego tezą o aspołecznym charakterze natury ludzkiej ${ }^{125}$.

\section{Ad 3}

Zdaniem Harta, ludzka natura nie jest ani skrajnie dobra, ani skrajnie zła. Twierdzi on, że nie jesteśmy ani szatanami, ani aniołami, co implikowałoby konieczność istnienia „sytemu wzajemnych wyrzeczeń” ${ }^{126}$. Pragniemy pomyślności nie tylko własnej, ale i innych ludzi. Niemniej są w nas tendencje agresywne, które winny być kontrolowane, tak by nie zagrażały przetrwaniu społeczeństwa (Hart nie używa słowa „wspólnota”, które jest nacechowane specyficzną, odległą od jego sposobu myślenia treścią).

Prawo zatem winno kontrolować naszą agresję oraz sprzyjać rozwojowi altruizmu. Niestety Hart nie podaje konkretnych rozwiązań.

\section{Ad 4}

Z faktu istnienia ograniczonej ilości zasobów potrzebnych człowiekowi wywodzi Hart konieczność istnienia własności oraz norm prawnych zabezpieczających jej istnienie. Co ciekawe, nie musi być to własność indywidualna.

123 Ibidem, s. 263.

124 W większym stopniu niż koncepcją Locke’a, w której umowa społeczna była dwuetapowa, a ograniczenie użycia przemocy nie było jej celem zasadniczym.

$125 \mathrm{Na}$ aspołeczny charakter naszej natury wskazuje na przykład psychoanaliza. Podkreśla się również fakt prowadzenia przez ludzkość wojen, a także wytworzenie potencjału pozwalającego na całkowite unicestwienie. Problem ten jest daleki od oczywistości.

126 H. L. A. Hart, Pojęcie prawa, s. 265. 
Istnienie norm zabezpieczających własność implikuje dalszy rozwój prawa kontraktów, na przykład umowy sprzedaży itd., a co ważniejsze - konieczny staje się system gwarantujący przestrzeganie tych norm.

Hart jest zatem w całkowitej opozycji do twierdzeń Rousseau o naturze własności. Jego zdaniem nie jest ona źródłem zła, lecz przeciwnie - stanowi element pozwalający społeczeństwu przetrwać.

\section{Ad 5}

Jest to postulat tworzenia takiego prawa, które minimalizuje ryzyko związane z poddaniem się temu systemowi prawnemu. Istnieje bowiem pokusa nadużycia sytemu przez tych, którzy nie chcą poddać się przymusowi prawnemu, kosztem tych, którzy temu przymusowi dobrowolnie się poddają. By ograniczyć możliwość nadużyć, konieczne jest wprowadzenie sankcji za przekroczenie normy prawnej. Co interesujące, zdaniem Harta, potrzeba walki z nadużyciami wynika ze słabości woli i rozumu ludzkiego ${ }^{127}$.

Odwracając argument Harta, należałoby powiedzieć, że gdyby rozumność i wola ludzka nie były ułomne, wszyscy dobrowolnie stosowaliby się do wymogów sytemu prawnego. Pogląd taki uznany może być za utopijny.

Podkreślić należy, że dla Harta prawem natury są ogólne przedstawione wyżej postulaty co do pożądanej (z uwagi na cel ludzkiej natury - przetrwanie) treści norm prawnych, ale także norm moralnych. Hart stara się zachować perspektywę empiryczną. Należy jednak stwierdzić, że nie jest to możliwe. Jego koncepcja bowiem przyjmuje wskazane w podrozdziale 3.4 założenia metafizyczne i epistemologiczne, które w najmniejszym stopniu nie są przez niego rozważane, a w sposób nieuprawniony przyjęte za oczywiste. Należy zatem przyznać rację Dworkinowi ${ }^{128}$ (choć wskazując inne niż on argumenty), który twierdzi, że Hart wyszedł poza opis. Mówiąc inaczej, wyszedł poza granicę metody empirycznej - za przedstawiciela której sam się uważał.

Wskazówką dla interpretacji idei minimalnej treści prawa natury może być analiza Hartowskiego pojęcia sprawiedliwości (Hart przedstawił jedynie jej szczątkowy zarys).

Sprawiedliwość według Harta polega na traktowaniu podobnych przypadków tak samo, zaś różnych odmiennie. Zauważa on, że ta ogólna zasada jest niewystarczająca. Dla jej pełni konieczne jest ustalenie kryterium

127 Ibidem, s. 266

128 Zob. podrozdział 3.1. 
traktowania podobnych przypadków jako podobnych bądź różnych ${ }^{129}$. Przy czym Hart twierdzi, że owo kryterium nie może zawierać się w samych tylko przepisach prawa ${ }^{130}$. Wskazuje, że czym innym jest sprawiedliwe stosowanie prawa, a czym innym sprawiedliwe prawo. Podaje on przykład prawa zakazującego wstępu ludziom o odmiennym od białego kolorze skóry do parków. Prawo takie może być stosowane w sposób sprawiedliwy, jeśli wszyscy będą jednakowo traktowani przy jego egzekwowaniu, tzn. wszyscy o innym kolorze skóry będą odpowiadali za naruszenie tego przepisu, wszyscy zaś biali będą mogli chodzić po parkach ${ }^{131}$. Jeśli kryterium traktowania podobnych przypadków tak samo zawierałoby się tylko w przepisach prawa, można by zastanawiać się nad tym, czy prawo to jest sprawiedliwie stosowane, ale nie czy jest ono sprawiedliwe. By móc orzec o tym, czy prawo jest sprawiedliwe, konieczne jest odwołanie do kryteriów pozaprawnych.

Wydaje się zatem, że Hart wskazuje jeszcze na jeden postulat dla minimalnej treści prawa natury. Mianowicie ma ono traktować podobne przypadki tak samo, różne zaś inaczej, według kryteriów zapewniających nam przetrwanie. Jednym $\mathrm{z}$ tych kryteriów wydaje się być równość ludzi. Nie formułuje on tego postulatu wprost. Wskazuje na to jednak podany przez niego przykład, którym uzasadnia on, że - co najmniej względna - równości ludzi jest czymś oczywistym. Jest to zatem postulat co do minimalnej treści prawa natury.

Wskazać trzeba, że równość wobec prawa spełnia wyłącznie kryterium sprawiedliwego stosowania prawa. Równość jako taka stanowi kryterium sprawiedliwości w ogólnym sensie.

Hart nie omawia koncepcji równości. Nie wskazuje, co przez nią rozumie. Wydaje się, że ma na myśli względnie równy dostęp do podstawowych dóbr. Należy powiedzieć, że koncepcja równości wobec prawa jest jednym z fundamentów kultury europejskiej. Budzi natomiast zastrzeżenia idea równości jako takiej. Przede wszystkim z uwagi na ograniczoną ilość zasobów. Poza tym wydaje się, że jej przesadne urzeczywistnianie powoduje zanik elit we współczesnym społeczeństwie. Przykładem niech będzie niedawne otwarcie dostępu do zawodów prawniczych lub sztuczne zrównanie uczelni wyższych przez System Boloński. Wydaje się, że zanik elit jest nieskuteczny dla celu, jakim jest przetrwanie społeczeństwa, niszczy bowiem naturalne aspiracje człowieka do wyróżnienia się na tle innych ludzi. Umasowienie

129 H. L. A. Hart, Pojęcie prawa, s. 216-217.

130 Ibidem, s. 219.

131 Ibidem, s. 219-221. 
zabija kreatywność i prowadzi do degradacji systemu politycznego ${ }^{132}$. Hart nie wypowiedział się w tym przedmiocie w sposób na tyle pełny, by można było poddać jego poglądy ocenie, warto jednak mieć ten ich aspekt na uwadze. Zbliża to bowiem jego poglądy do koncepcji prawa natury Gustava Radbrucha (przy całej odmienności jego sposobu postrzegania prawa), dla którego równość jest rdzeniem sprawiedliwości ${ }^{133}$. Jeśli ustawodawca świadomie tworzy prawo zaprzeczające tej elementarnej zasadzie, to taki zapis nie mieści się w definicji prawa - niezgodny jest bowiem z ideą prawa. Hart ma inny pogląd. O tym, czym jest prawo, decyduje reguła uznania. A zatem odniesieniem Harta jest realne, empirycznie weryfikowalne życie społeczne. Odniesieniem dla Radbrucha jest zaś idea prawa, a zatem spekulacja filozoficzna. Oceniając filozofię Harta z tej perspektywy, należy wskazać, że nie udało mu się nie wyjść poza zakres metody empirycznej. Do takiego wniosku prowadzi analiza jego koncepcji minimalnej treści prawa natury, która przyjmuje za oczywiste wskazane wyżej założenia metafizyczne, epistemologiczne oraz etyczne, bez dostatecznej ich analizy. Fakt ten dla oceny poglądów Harta winien mieć znaczenie fundamentalne.

Abstrahując od powyższego wywodu, wskazać należy, że pojęcie równości ma dla filozofii prawa znaczenie podstawowe. Hart zdaje się je rozumieć w sposób odmienny od Radbrucha. Dla tego ostatniego równość wydaje się polegać na traktowaniu człowieka jako podmiotu ${ }^{134}$, a nie jako przedmiotu prawa, co jest echem Kantowskiego imperatywu praktycznego. Hart natomiast odwołuje się do idei równości jako takiego samego dostępu do dóbr. Co interesujące, Hart jeszcze przed publikacją Teorii sprawiedliwości J. Rawlsa wspomina o możliwości sformułowania następującej tezy: „wybór pomiędzy rywalizującymi roszczeniami czy też interesami rozmaitych klas ${ }^{135}$ dokonuje się dla interesu ogólnego, jeśli zostały one bezstronnie rozpatrzone przed podjęciem decyzji” ${ }^{\prime 36}$. Nie rozbudowuje jednak tego wątku. Podkreśla

132 Por. M. Leleno-Czarnak, Nonkonformizm jako warunek trwania demokracji, w: M. Szyszkowska (red.), Demokracja i niepospolite jednostki, Tarnów 2013, s. 322-332.

133 Zob. G. Radbruch, Ustawowe bezprawie i ponadustawowe prawo, w: M. Szyszkowska, Zarys europejskiej filozofii prawa, s. 282.

134 Autor celowo unika terminu „osoba”. Jest to bowiem termin rozmaicie rozumiany. W zupełnie podstawowym rozumieniu pojęcie „osoba” implikuje traktowanie człowieka jako podmiotu, nie zaś przedmiotu. Na gruncie kantyzmu osoba to człowiek jako cel sam w sobie. Szeroko pojęta tradycja Lockowska z Peterem Singerem na czele podkreślać będzie samoświadomość jako wyróżnik tego pojęcia.

135 „Klasa społeczna” jest pojęciem marksistowskim. Jego użycie niesie za sobą określoną treść. Zakłada na przykład ich antagonistyczny charakter. Hart wydaje się używać go w sposób bezwiedny, co jest także nagminnym błędem na gruncie polskiej filozofii. Jeśli nie jest naszym zamiarem odwołanie się do marksizmu, powinniśmy używać neutralnego terminu „warstwa społeczna”.

136 H. L. A. Hart, Pojęcie prawa, s. 227. 
jedynie doniosłość bezstronności dla rozważania wzajemnych roszczeń co do możliwości uzyskania korzyści.

Na marginesie należy wspomnieć, że projekt Rawlsa, zakładający możliwość absolutnej bezstronności, budzi zastrzeżenia. Wydaje się, że polega on na błędnym zrozumieniu kantyzmu i wymieszaniu sfery noumenalnej ze sferą fenomenów. Wydaje się, że taki byt jak człowiek znajdujący się za zasłoną niewiedzy i odnoszący się do świata empirycznego, na gruncie kantyzmu nie może istnieć. Jako homo noumenon człowiek jest całkowicie wolny, a wolność ta polega właśnie na oderwaniu od empirii, nie na odnoszeniu się do niej - nie jest to jednak temat niniejszej publikacji. Niemniej warto mieć na uwadze, że analiza pojęcia bezstronności ma dla filozofii prawa istotne znaczenie.

\subsection{AKTUALNOŚĆ FilozofiI PRAWA Herberta Harta}

Filozofia prawa opracowana przez Herberta Harta stanowi egzemplifikację jednej z perspektyw badawczych zaproponowanych przez profesora Marka Zirc-Sadowskiego. Polega ona na analizie zjawisk prawnych i wyprowadzaniu z nich wniosków mających znaczenie dla filozofii. Jest to podejście odmienne od tradycyjnego, dla którego punktem wyjścia dla analizy prawa są określone poglądy filozoficzne. Pierwsza perspektywa nazwana została od prawa ku filozofii (punktem wyjścia rozumowania jest prawo), druga od filozofii ku prawu (punktem wyjścia rozumowania jest filozofia) ${ }^{137}$.

Dorobek filozoficzno-prawny Herberta Harta należy podzielić na trzy części. Pierwsza dotyczy tego, czym prawo nie jest, druga tego, czym prawo jest, a trzecia stanowi wskazówki co do tego, jakim prawo być powinno.

Rozważań wchodzących w skład pierwszej części nie sposób przecenić. Przede wszystkim Hart w sposób niepodważalny wykazał fałszywośćc ${ }^{138}$ założeń pierwotnego (twardego) pozytywizmu prawnego. Co ważne, dokonał tego, analizując funkcjonowanie obowiązujących norm prawnych. Jego wnioski sformułowane zostały zatem w oparciu o badania empiryczne. Prawo nie

137 M. Zirk-Sadowski, Wprowadzenie do filozofii prawa, s. 7-8.

138 Hart odnosi się z estymą do dzieł Austina i pisze o niewystarczalności, a nie fałszywości jego poglądu na prawo. Niemniej obala jego główne tezy. 
jest rozkazem suwerena zabezpieczonym przymusem, a jego analiza nie jest możliwa wyłącznie na drodze wnioskowań logicznych, które nie powodują dodania zewnętrznych treści do wyniku rozumowania. Hart nawiązuje do dokonań filozofii języka. W szczególności do wzajemnych oddziaływań pojęć prawnych na rzeczywistość i odwrotnie. Słownik pojęć prawnych nie może więc stanowić zamkniętego, odrębnego i niezależnego sytemu.

Krytyka założeń pierwotnego pozytywizmu prawnego doprowadziła Harta do twierdzeń o tym, czym prawo jest. Przede wszystkim twierdzi on, że prawo można poznać w pełni jedynie w odniesieniu do całości życia społecznego. Otwartość oraz kontekst nabierają dla Harta znaczenia fundamentalnego. Prawo przestaje być sztucznym tworem abstrakcyjnego suwerena, a staje się elementem życia społecznego. Jest ono otwarte na krytykę z pozycji moralnych, zwyczajowych i innych. Jego treść jest także współtworzona przez kontekst, w jakim jest stosowane. Interesującym jest to, że tezy Harta w przedstawionym wyżej zakresie są prawdziwe również na gruncie polskiego sytemu prawnego. W szczególności wskazać należy na istotę języka prawnego, który nie jest metajęzykiem, ale rejestrem języka etnicznego. Znaczenia zawartych w nim nazw częstokroć zależą od kontekstu ich użycia. Na polskim gruncie większe znaczenie mają definicje legalne, niemniej nie stanowią one całości sytemu prawnego, który w swych założeniach pozostaje otwarty dzięki wyrażeniom niedookreślonym, klauzulom generalnym oraz odwołaniom do zasad prawa, a czasem również do wartości. Na uwagę zasługuje też możliwość stosowania przez sąd różnych metod wykładni oraz teoretyczna możliwość odstąpienia od wykładni językowej, gdy jej efekt sprzeczny byłby z powszechnie uznanymi normami etycznymi. Praktyka jest tu niestety odmienna. Niemniej z pozytywizmu Harta płynie przyzwolenie na taką działalność sędziowską, co może być uznane za najbardziej doniosłą spuściznę jego dorobku, albowiem sformułowaną z perspektywy pozytywizmu prawnego, a zatem tego kierunku w filozofii prawa, który odpowiedzialny był za próbę wyrugowania aksjologii z metody prawoznawstwa.

Na gruncie niewątpliwie słusznych obserwacji Hart stworzył rozbudowaną teorię prawa. Projekt ten nie zakończył się jednak pełnym sukcesem. Przede wszystkim wątpliwości budzi rozumienie przez Harta normy moralnej i wskazane przez niego cechy mające odróżniać ją od normy prawnej. Niemniej jego teoria pokazuje, że prawo jest związkiem reguł pierwotnych i wtórnych oraz zasad prawa (należy pamiętać, że kilkadziesiąt lat po publikacji pierwszego wydania swego głównego dzieła Hart zauważył potrzebę zaadaptowania do swej filozofii zasad prawnych postulowanych przez Dworkina). Jego teoria 
ma dla filozofii prawa znaczenie niezwykle istotne. Przede wszystkim jest ona teorią pozytywistyczną, która odcina się od tez swej poprzedniczki i to w sposób niepozwalający umysłowi stosującemu zasady logiki na powrót do założeń pierwotnego pozytywizmu prawnego. Teorię prawa Harta traktować należy nie jako tę, która pozwalałaby na precyzyjne zdefiniowanie prawa, ale jako teorię wskazującą na jego cechy charakterystyczne, bez przesądzania o tym, czy są one zupełne. Takie spojrzenie zgodne jest $\mathrm{z}$ pojmowaniem przez Harta (i jego środowisko naukowe) istoty definiowania.

Trzecią część dorobku Harta stanowi jego koncepcja minimalnej treści prawa natury, z której wynikają ogólne wytyczne co do treści prawa. Jego zdaniem koncepcja ta zbudowana jest na obserwacji sprowadzającej się do tego, że ludzie dążą do przeżycia, a zatem prawo ma zapewnić możliwość realizacji tych dążeń. Nie jest jednak możliwym zbudowanie teorii prawa natury bez przyjęcia szeregu wskazanych w niniejszej publikacji założeń filozoficznych. Przede wszystkim twierdzenie, że istnieje natura ludzka, jest już samo w sobie tezą metafizyczną. Teza zaś, że ludzie powinni realizować poznany cel swojej natury, jest tezą aksjologiczną i epistemologiczną. Nie znaczy to, że tezy te są błędne. Niewątpliwie jednak wykraczają poza metodę empiryczną, a tego Hart pragnął uniknąć. Błędne jest twierdzenie Harta, że teoria jego wynika wyłącznie z obserwacji. Ponadto w jego twierdzeniach zawarte jest założenie, którego nie omawia. Mianowicie, wskazując, jakie prawo być powinno w oparciu o obserwację, łączy Hart sferę bytu i powinności, co z punktu widzenia wielu koncepcji filozoficznych jest błędem (wymaga zatem uzasadnienia).

Ponadto wydaje się, że to nie przetrwanie stanowi zasadnicze dążenie człowieka, ale chęć tworzenia kultury. Przetrwanie jest dla tego dążenia wtórne. Jeśli można mówić o czymś, co w sferze doświadczenia wyróżnia człowieka, to jest to przetwarzanie zastanego otoczenia, którego efektem jest dopiero przetrwanie (choć nie zawsze).

Abstrahując od zagadnienia dotyczącego tego, czym jest zasadnicze dążenie człowieka, warto powiedzieć, że słowo „przetrwanie” jest wieloznaczne. Nawet godząc się na to, że jest i powinno ono być celem człowieka, należałoby rozważyć, jakie działania zapewnią jego realizację. Innymi słowy, jak należy skonstruować system prawny sprzyjający ludzkiemu przetrwaniu. Na to pytanie Hart nie odpowiada. Nie odnajdziemy w jego filozofii odpowiedzi na pytanie, czy dla przetrwania konieczne jest jedynie zapewnienie realizacji niższych wartości (zapewniających dobrobyt - użytkowych), czy też konieczne jest odniesienie do wartości wyższych (ideałów). Jest to problem niezwykle ważny albowiem wydaje się, że realizacja wyłącznie 
wartości niższych (użytkowych) prowadzi nie do przetrwania, ale do zagłady społeczeństwa. Jeśli zaś stwierdzimy, że do przetrwania potrzebne jest odniesienie do wartości wyższych, to moc wyjaśniająca filozofii Harta spada do zera. Przesuwa bowiem jedynie problem, nie rozwiązując go. Zamiast pytać o aksjologię prawa, zadać by trzeba pytanie o aksjologię przetrwania.

Autor niniejszej publikacji nie odpowie na pytanie, co składa się na warunki przetrwania społeczeństwa. Nie chce też nawiązywać do wielkich systemów filozoficznych, na przykład do filozofii Radbrucha, dla którego jest oczywistością, że wszelka ludzka działalność stanowi próbę urzeczywistnienia ideałów (mają one znaczenie pierwotne). Pragnie jedynie wskazać - ograniczając się w tym miejscu tylko do perspektywy empirycznej - że bardziej prawdopodobna jest teza, że realizacja wyłącznie wartości niższych (użytkowych) prowadzi do zagłady, niż teza, że realizacja tych wartości zapewnia przetrwanie. Jeśli tak jest, to koncepcja minimalnej treści prawa natury udziela jedynie pozornej odpowiedzi. Znaczącej wskazówki w tym zakresie dostarczają rezultaty znanego eksperymentu na szczurach Calhouna ${ }^{139}$. Z punktu widzenia niniejszej publikacji istotne jest to, że Calhoun poddał eksperymentowi populacje szczurów, zapewniając im maksymalnie dobre warunki, w szczególności nieograniczoną ilość pożywienia oraz opiekę medyczną. Co istotne, szczury nie zasiedliły całości przeznaczonego dla nich terytorium, zatem warunkiem ograniczającym nie był brak przestrzeni (gromadziły się one dobrowolnie w zatłoczonych wybranych gniazdach - nie jest to jednak istotne z punktu widzenia niniejszego tekstu). Początkowo populacja szczurów szybko rosła. Następnie przyrost populacji zaczął spadać. Pomimo dostępności wszelkich zasobów, populacja całkowicie straciła zdolności reprodukcyjne, co doprowadziło do wymarcia. Ostatnie gryzonie straciły zainteresowanie prokreacją oraz wyzbyły się zachowań agresywnych. Osobniki zainteresowane były jedynie sobą. Były piękne oraz zdrowe, ale niezdolne do podejmowania wyzwań. Pomimo doskonałego stanu zdrowia, nie rozmnożyły się. Co interesujące, we wcześniejszych pokoleniach (gdy jeszcze populacja jako taka była zdolna do rozmnażania) zaobserwowany został zanik agresji oraz potrzeby dominacji u samców, zaś zachowania agresywne przejmowane były przez samice i wyrażane w patologiczny sposób (na przykład w stosunku do młodych). Powszechne były również zachowania homoseksualne (ich rola znacząco wzrosła). Rezultaty eksperymentu były rozmaicie interpretowane.

139 J. B. Calhoun, Death Squared: The Explosive Growth and Demise of a Mouse Population, „Proceedings of the Royal Society of Medicine" 1973, t. 66, s. 80-88. 
Nie ulega jednak wątpliwości, że brak wyzwań doprowadził do zagłady populacji. Zapewnienie nieograniczonych zasobów spowodowało wymarcie, zanim szczury zdołały zasiedlić całe przeznaczone dla nich środowisko.

Wykorzystywanie wyników eksperymentów na szczurach do analizy życia ludzi może budzić wątpliwości. Nie jest to argument przesądzający, niemniej wskazuje na prawidłowości, które dostrzegalne są także w naszym życiu. Powszechnie znane dane demograficzne potwierdzają zmniejszenie zainteresowania prokreacją wśród ludzi uformowanych przez ideologię wyrzeczenia się agresji oraz równości, propagowaną np. w bogatych krajach Unii Europejskiej. Także wzrost znaczenia w kulturze masowej zachowań homoseksualnych może być odczytywany jako analogiczny do występującego w eksperymencie Calhouna ${ }^{140}$. Powszechnie znane jest również zjawisko zaniku ról męskich i podejmowania ich przez kobiety.

Argumenty te nie przesądzają, ale uprawdopodabniają tezę, że dla przeżycia konieczna jest możliwość podejmowania przez człowieka wyzwań - w sensie realizacji celów innych niż zaspokojenie potrzeb biologicznych. Wydaje się zatem, że prawdopodobną jest teza, iż do przeżycia człowieka konieczne jest odniesienie się do wartości wyższych. Jeśli tak, to koncepcja Harta jest absolutnie niewystarczająca, przesuwa bowiem odwieczne pytanie o wartości wyższe do sfery przetrwania. Takie wyjaśnienie jest pozorne, nie rozwiązuje bowiem problemu, ale go rozmywa.

Powyższa teza nie zmienia faktu, że w warstwie krytycznej filozofia Harta jest dziełem doniosłym. Hart wyciągnął ostateczne wnioski, jakie mogą zostać wyciągnięte przy zastosowaniu metody empirycznej. Wykazał przede wszystkim wadliwość pierwotnego pozytywizmu prawnego. Jednak analiza jego filozofii pozytywnej wskazuje, że metoda bazująca na opisie jest niewystarczająca dla rozważań nad zjawiskami oraz pojęciami prawnymi.

Niezwykle doniosłym wnioskiem płynącym $z$ analizy poglądów Harta jest teza, że z pozytywizmu prawnego płynie postulat istnienia prawa natury. Nie mają tu znaczenia zastrzeżenia co do jego poglądów na postrzeganie prawa natury. Ważne jest to, że takie prawo jest konieczne.

Odpowiadając na pytanie o aktualność filozofii prawa Herberta Harta, należy powiedzieć, że można o niej mówić na trzech poziomach analizy.

140 Homoseksualizm jest zjawiskiem naturalnym, albowiem występuje w naturze oraz ludzkiej kulturze co najmniej od czasów dostępnych ludzkiemu poznaniu. Niemniej rola homoseksualizmu w kulturze zmienia się. Nie można wykluczyć, że nasilenie takich zachowań jest wskaźnikiem kondycji społeczeństwa i preludium jego rozpadu - podobnie jak zanik agresji u mężczyzn. Przedstawiona teza nie polega na tym, że homoseksualizm może być przyczyną zagłady, ale na tym, że nasilenie tych zachowań może świadczyć o niebezpieczeństwie wymarcia społeczeństwa (ściślej mówiąc - białych mieszkańców Europy). 
Pierwszym poziomem jest poziom opisu. Hart trafnie i rzetelnie analizuje aktualne zjawiska prawne. Jego koncepcja zgodna jest także z obowiązującym w Polsce systemem prawnym (osobnym zagadnieniem jest jego funkcjonowanie, sędziowie niechętnie korzystają z dawanych im przez system możliwości, które mogą ich narazić na krytykę i wymagają większego zaangażowania i wkładu intelektualnego - zagadnienie to wykracza poza ramy niniejszej publikacji, najkrócej mówiąc związane jest to $\mathrm{z}$ dominacją rozumu instrumentalnego). Warto wskazać, że pozostając na etapie opisu, bardziej uprawnione jest mówienie o teorii prawa niż o filozofii prawa. Należy zatem powiedzieć, że teoria prawa Harta zachowała aktualność.

Drugim poziomem aktualności koncepcji Harta są wnioski, jakie płyną z jego teorii. Wskazuje on bowiem, że implikuje ona konieczność uwzględnienia minimalnej treści prawa natury w systemie prawa (warto przypomnieć, że system ten cechuje otwartość, co nie odpowiada pojęciu systemu wypracowanemu przez logikę klasyczną). Konieczności uwzględnienia prawa natury przez organy państwa trudno odmówić aktualności. Jest to bowiem postulat o charakterze uniwersalnym i ponadczasowym. Jego wartość jest tym cenniejsza, że wywiedziony został z pozytywizmu prawnego.

Trzecim poziomem aktualności teorii Harta jest spojrzenie z perspektywy rozwoju filozofii prawa. Perspektywę tę można nazwać metaanalizą. Mianowicie, we współczesnej filozofii prawa zaciera się granica pomiędzy pozytywizmem prawnym a koncepcjami prawno-naturalnymi. Z jednej strony, z pozytywizmu prawnego płynie wniosek, że konieczne jest minimum prawa naturalnego, $\mathrm{z}$ drugiej zaś - z koncepcją prawa natury nie jest już koniecznie związana teza o niezmienności jego treści (przykładem jest filozofia Radbrucha). Uzasadnione wydaje się zatem twierdzenie o swoistej syntezie $\mathrm{w}$ dziedzinie filozofii prawa.

Należy podkreślić, że wyrafinowany pozytywizm prawny można również rozumieć jako nieudaną próbę opisu prawa, która w zamierzeniu Harta miała zachować neutralność w stosunku do etyki. Uzasadniona jest wtedy wspomniana wcześniej teza o śmierci pozytywizmu prawnego, a nawet wykazywanie jego niespójności ${ }^{141}$. Autor niniejszej publikacji - z uwagi na ogromną moc wyjaśniającą koncepcji Harta - proponuje bardziej życzliwy sposób jej odczytania. Może być ona bowiem traktowana jako koncepcja niewystarczająca dla uzasadnienia całości zjawisk prawnych nie jako wewnętrz-

141 Zob. J. Finnis, On the Incoherence of Legal Positivism, „Notre Dame Law Review” 1999-2000, t. 75, s. 1597-1612. 
nie sprzeczna lub błędna. Podkreślić należy, że proponowana interpretacja zakłada, iż zawarty jest w niej moralny aspekt uzasadnienia sytemu prawa pozytywnego (minimalna treść prawa natury), co tradycyjnie przypisywane jest koncepcjom prawa natury i określane jako teza o koniecznej zależności prawa pozytywnego od jego statusu etycznego ${ }^{142}$. W literaturze podkreśla się, że zależność ta powoduje konieczność oparcia teorii prawa na koncepcji racjonalności praktycznej ${ }^{143}$. W tym sensie można powiedzieć, że potrzeba uzupełnienia pozytywizmu prawnego o koncepcje racjonalności praktycznej jest wnioskiem $z$ analizy filozofii Harta. Jej twórca potrzeby takiej nie artykułował. Niewątpliwie był on jednak otwarty na argumenty tradycyjnie przypisywane teoriom prawa natury, o czym świadczy nie tylko jego koncepcja minimalnej treści prawa natury, ale również to, że poprosił on Johna Finnisa o napisanie książki pod tytułem Prawo naturalne i uprawnienia naturalne ${ }^{144}$. Finnis twierdzi, że nie tylko sformułował on temat jego najbardziej znanej publikacji, ale, co ważniejsze, nie skrytykował jej podstawowych twierdzen ${ }^{145}$.

Abstrahując od zagadnień interesujących dla historyków filozofii, należy podkreślić, że filozofia prawa Herberta Harta niewątpliwie wymaga uzupełnienia. Podstawowymi tego powodami są:

1. brak wskazania oraz wyjaśnienia przyjętych założeń filozoficznych,

2. trudności w zdefiniowaniu relacji pomiędzy normą prawną a moralną,

3. pozorny charakter „przetrwania” jako minimalnej treści prawa natury,

4. brak dostatecznego uzasadnienia obowiązku przestrzegania norm prawnych.

\section{Ad 1}

Pomimo braku omówienia przez Harta własnych założeń filozoficznych, zasadniczą wartością teorii Harta wydaje się być wyjaśnienie funkcjonowania realnie istniejących systemów prawnych oraz wykazanie na tej podstawie błędów pierwotnego pozytywizmu prawnego, a także sformułowanie postulatu minimalnej treści prawa natury. Unikanie analizy epistemologicznej oraz metafizycznej nie umniejsza wartości teorii w powyższym zakresie. Warto na marginesie zaznaczyć, że analogiczny, aczkolwiek skierowany w przeciwną

142 Zob. J. Crowe, Natura Law Beyond Finnis, „Jurisprudence” 2011, t. 2, s. 293-308.

143 Ibidem, s. 296. Crowe twierdzi, że koncepcja etycznego uzasadnienia obowiązku podlegania prawu jest zasadniczym wyróżnikiem tzw. Nowej Koncepcji Prawa Naturalnego. Pozytywizm prawny Harta wyróżnia jego zdaniem to, że obowiązywanie norm prawnych uzasadnione jest jedynie za pomocą „społecznie rozpoznanych faktów oraz zdarzeń”.

144 J. Finnis, Natural Law and Natural Rights (Second Edition), Oxford 2011, s. 414.

145 Ibidem, s. 415. 
stronę, zarzut można nierzadko postawić filozofom rozważającym ostateczne podstawy obowiązywania prawa. Doniosłość ich zasadniczej teorii nie powstrzymuje ich przed formułowaniem błędnych wniosków odnoszących się do konkretnych spraw życia społecznego. Za przykład niech posłuży $\mathrm{np}$. zerwanie podstawowych relacji rodzinnych z uwagi na interes państwa postulowany przez Platona dla niektórych warstw społecznych, aprobowanie niewolnictwa przez Arystotelesa, czy wskazywanie na zasadność podporzadkowania się kobiet decyzjom mężczyzn przez Tomasza z Akwinu.

\section{Ad 2}

Wydaje się, że trudności w zdefiniowaniu relacji pomiędzy normą prawną a moralną stanowią konsekwencję punktu 1., a także swoistego dynamizmu poglądów Harta, który - w szczególności w replice na zarzuty Dworkina - inaczej rozkładał akcenty swojej teorii. Należy jednak podkreślić, że wyraźnie sprzeciwiał się on stanowisku Kelsena, według którego nauka prawa nie bierze pod uwagę norm moralnych jako systemu norm obowiązujących oraz analogicznie, nauka o moralności nie bierze pod uwagę norm prawnych jako systemu norm obowiązujących ${ }^{146}$.

\section{Ad 3}

Pomimo doniosłości samej koncepcji minimalnej treści prawa natury, sprowadzenie jej wyłącznie do przetrwania stanowi jedynie pozorne kryterium oceny treści prawa. Pojawia się bowiem potrzeba rozważenia tego, jak należy owo przetrwanie rozumieć, co - jak zostało wskazane - przesuwa jedynie pytanie o aksjologię prawa na poziom aksjologii przetrwania.

\section{Ad 4}

Zagadnienie uzasadnienia obowiązku przestrzegania prawa ma znaczenie kluczowe dla konieczności uzupełnienia teorii pozytywizmu prawnego. Wskazać należy, że obowiązku tego nie sposób uzasadnić bez odwołania do koncepcji rozumności praktycznej. Zagadnienie to zostanie omówione $\mathrm{w}$ następnym rozdziale.

146 H. L. A. Hart, Eseje..., s. 306-307. Zdaniem Kelsena nie jest możliwe obowiązywanie dwóch sprzecznych norm, np. normy prawa pozytywnego nakazującej odbycie służby wojskowej oraz normy moralnej zakazującej zabijania ludzi. Kelsen taką sytuację tłumaczy poprzez odwołanie do faktów psychicznych, które pchają jednostkę w przeciwnych kierunkach. Głosi on nie tylko rozdział prawoznawstwa od etyki, ale również wyklucza istnienie innych perspektyw obejmujących aspekty prawa oraz etyki. Co więcej, twierdzi, że sformułowanie zdania stwierdzającego konflikt pomiędzy normą prawa stanowionego a normą etyczną jest logicznie niemożliwe. 


\section{Koncepcja rozumności praktycznejjakouzupełnienie pozytywizmu prawnego Herberta Harta}

W rozdziale zarysowana zostanie koncepcja rozumności praktycznej stanowiąca rdzeń tzw. nowej teorii prawa naturalnego - jako uzupełnienie filozofii prawa Herberta Harta. W tym celu w podrozdziale 4.1 omówione zostaną podstawowe twierdzenia nowej teorii prawa naturalnego, ze szczególnym uwzględnieniem poglądów Johna Finnisa. W podrozdziale 4.2 ukazane zostaną argumenty przemawiające za koniecznym charakterem tego uzupełnienia.

\subsection{ZARYS KONCEPCJI TZW. NOWEJ TEORII PRAWA NATURALNEGO}

Wskazać należy, że przymiotnik „nowa” nie oddaje intencji jej autorów, w szczególności zaś nie koresponduje z twierdzeniami centralnej postaci dla nowej koncepcji prawa natury, Johna Finnisa. Jego zdaniem koncepcja ta 
jest zgodna $\mathrm{z}$ twierdzeniami Tomasza $\mathrm{z}$ Akwinu, a zatem jest ona w swym rdzeniu teorią klasyczną. Podkreślić przy tym należy, że Finnis uznaje, iż Arystoteles i Tomasz z Akwinu chętnie przystaliby na to, że nie można wydedukować „powinien” z ,jest”, co stanowi jedną z kluczowych tez omawianych teorii. Niemniej zarówno Finnis, jak i inni przedstawiciele tej szkoły uważają, że filozofia św. Tomasza wymaga dopracowania ${ }^{2}$. Należy mieć jednak na uwadze i to, że odwołania do klasycznych teorii filozoficznych nie mają znaczenia kluczowego, a tzw. nowa teoria prawa naturalnego może być rozumiana jako niezależny pogląd na prawo oparty na koncepcji rozumności praktycznej. Na marginesie warto również dodać, że zarówno Finnis, jak i inni autorzy utożsamiani z tym sposobem myślenia (np. Joseph Boyle czy Robert George) znani są konserwatywnych poglądów m.in. na temat aborcji. W literaturze przedmiotu podkreśla się jednak, że teorię tę można rozważać w oderwaniu od poglądów jej autorów dotyczących szczegółowych zagadnień życia społecznego ${ }^{3}$.

Cechą wyróżniającą przedmiotowe teorie jest podkreślanie istnienia koniecznych związków pomiędzy etyką a teorią prawa, a co za tym idzie wskazanie na związek pomiędzy moralnością a obowiązkiem podporządkowania się prawu ${ }^{4}$. To zaś prowadzi do powiązania teorii prawa $\mathrm{z}$ koncepcją rozumności praktycznej ${ }^{5}$.

Teorie te wskazują na wielość podstawowych form ludzkiego rozwoju rozumianych jako „dobra” oraz na ich logiczne pierwszeństwo w stosunku do prawa (uprawnienia) ${ }^{6}$. Finnis wskazuje, że tak pojęte dobra są nieredukowalne oraz podstawowe. Nie są również wywiedzione $\mathrm{z}$ wcześniej poczynionych założeń ${ }^{7}$. Jego zdaniem, można w nich uczestniczyć na nieskończenie wiele sposobów, są oczywiste, a w konsekwencji - nie wymagają dowodu. Są rozumną racją działania, a jednocześnie stanowią „aspekt autentycznego rozwoju człowieka”" Odnosząc się do klasycznej terminologii, Finnis wskazuje, że stanowią one pełnię realizacji ludzkiej potencjalności. Warto przy tym zaznaczyć, że ich źródłem nie jest wiedza o ludzkiej naturze, lecz „są one raczej rezultatem naszego rozumienia inteligibilnych przedmiotów ludzkiej

\footnotetext{
1 J. Finnis, Prawo naturalne..., s. 56.

2 Zob. ibidem, s. 55.

3 Zob. J. Crowe, Natural Law Beyond Finnis, s. 294, 296.

4 Ibidem, s. 295.

5 Ibidem, s. 295-296.

6 Ibidem, s. 297.

7 J. Finnis, Natural Law and Natural Rights..., s. 439.

8 J. Finnis, Prawo naturalne..., s. 74.
} 
woli oraz czynów"', przy czym podkreślić należy, że Finnis wskazuje, iż to nie ludzka wola jest tu aspektem kluczowym, ale właśnie owa „pojmowalność” ludzkich czynów oraz pragnień w aktach rozumowania praktycznego ${ }^{10}$.

Finnis wskazuje, że omawiane dobra mają charakter przedmoralny. Stanowią jednak konieczny substrat sądu moralnego" ${ }^{11}$. Ponadto $\mathrm{z}$ uwagi na skończony charakter ludzkiego życia, wymienia nie tylko podstawowe formy ludzkiego dobra, ale także zasady rozumnego w nich uczestniczenia (podstawowe formy rozumności praktycznej) $)^{12}$. Te ostatnie - jako zasady metodologiczne - same stanowią dookreślenie jednego z podstawowych dóbr, jakim jest rozumność praktyczna. Zastosowanie tych zasad nadaje wartość moralną czynom realizującym dobra podstawowe ${ }^{13}$.

Prawo naturalne w ujęciu Finnisa jest metodą formułowania sądu moralnego lub etycznego na podstawie dostępnych racji postępowania (dóbr podstawowych) oraz rozumnego w nich uczestnictwa (zasad rozumności praktycznej) ${ }^{14}$. Podkreślić przy tym należy, że metoda ta nie opiera się zdaniem Finnisa - na analizie bytu realnie istniejącego, ale samej władzy poznania praktycznego. Nie wywodzi się tu zatem twierdzeń o powinnościach na podstawie twierdzeń o rzeczywistości empirycznej $j^{15}$.

Finnis w odpowiedzi na krytykę ze strony przedstawicieli klasycznego rozumienia prawa natury, wskazuje, że w porządku ontycznym znaczenie pierwotne ma nie władza poznawcza, ale natura ludzka, albowiem zarówno przedmioty woli, jak i ludzkie działania zależne są od ludzkich możliwości, które z kolei podyktowane są ludzką naturą ${ }^{16}$.

W literaturze przedmiotu podkreśla się, że z faktu istnienia podstawowych dóbr oraz związanych z nimi zasad rozumności praktycznej - dla przedstawicieli nowej teorii prawa naturalnego, w tym dla Finnisa - wynika krytyka konsekwencjonalizmu, a zatem również wszelkich form utylitary$\mathrm{zmu}^{17}$. Finnis krytykuje zarówno utylitaryzm reguł, jak i utylitaryzm czynów. Zarzuca im nie tylko faktyczną niewykonalność postulatu maksymalizacji dobra w świecie oraz arbitralność doboru służących temu reguł lub czynów, ale - co ważniejsze - uznaje metodologiczny nakaz maksymalizacji dobra

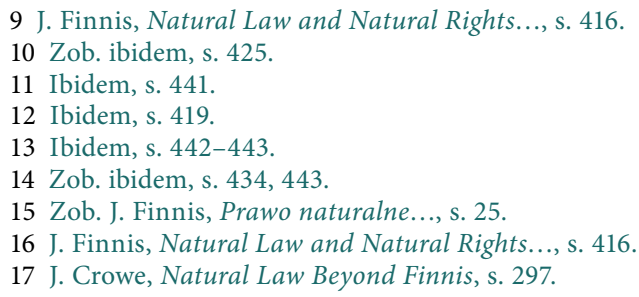


za irracjonalny, „jak próba zsumowania wymiarów tej strony, liczby sześć i masy tej książki”"18. Finnis posługuje się tym barwnym określeniem, by podkreślić, że nie sposób wyróżnić dla człowieka jednego dominującego celu (dobra), oraz że cele te nie dają się sprowadzić do wspólnego mianownika ${ }^{19}$. Wyklucza on zatem sensowność definiowania najwyższego celu w postaci na przykład odniesienia najdoskonalszej władzy poznawczej w najdoskonalszy sposób do najdoskonalszego przedmiotu poznania (racjonalnego oglądu Absolutu) czy osobowej relacji z Bogiem.

Zdaniem autora wskazać należy na pewną niekonsekwencję w wywodzie Finnisa. Tłumaczy on bowiem dobra podstawowe jako racjonalną realizację pełni ludzkich możliwości, a zatem sprowadza on dobra podstawowe do wspólnego mianownika (co sam uznał za działanie błędne). Zarzut ten łagodzi nieco pogląd Finnisa wskazujący, że postulatu realizacji pełni ludzkich możliwości nie należy rozumieć jako celu, ale jako ideę rozumu ${ }^{20}$. Chociaż argumentacja Finnisa wydaje się niewystarczająca, to wskazać należy, że zarówno Finnis, jak i inni przedstawiciele nowej teorii prawa naturalnego kładą nacisk na uczestnictwo w podstawowych wartościach, a nie maksymalizowanie jednej z nich.

W literaturze przedmiotu podkreśla się, że z logicznego pierwszeństwa dóbr podstawowych nad prawem stanowionym wynika krytyka najbardziej popularnych form deontologii (nie obowiązek przestrzegania prawa, bądź nakazów innego rodzaju jest punktem wyjścia tego sposobu myślenia o prawie, ale fakt istnienia dóbr podstawowych) ${ }^{21}$. Sam zaś Finnis odcina się od poglądu, w myśl którego jego filozofia inspirowana jest myślą Kan$\operatorname{ta}^{22}$. Niemniej uznaje jego imperatyw kategoryczny za jedno z wymagań rozumności praktycznej ${ }^{23}$. Wskazać należy, że to dobra podstawowe stanowią rdzeń jego koncepcji, bezpośrednim źródłem nie jest dla niego obowiązek ani prawo. Zdaniem komentatorów, pamiętać jednak należy, że źródłem dla dóbr podstawowych są wskazania rozumu praktycznego. Ich wymagania nie są kategoryczne, jak w filozofii Kanta, nadają jedynie sensowny kierunek ludzkiej woli. Podkreślają oni, że dobra podstawowe są w nowej teorii prawa naturalnego wartościami samymi w sobie, nie służą osiągnięciu celu leżącego

18 J. Finnis, Prawo naturalne..., s. 126.

19 Ibidem, s. 126.

20 J. Finnis, Natural Law and Natural Rights..., s. 451.

21 J. Crowe, Natural Law Beyond Finnis, s. 297.

22 J. Finnis, Natural Law and Natural Rights..., s. 417, 435.

23 J. Finnis, Prawo naturalne..., s. 136. Finnis definiuje omawiany wymóg rozumności praktycznej jako „respektowanie każdej podstawowej wartości w każdym poszczególnym działaniu. Niemniej wprost cytuje imperatyw kategoryczny jako inne jego sformułowanie. 
poza nimi ${ }^{24}$. Rozumność praktyczna - jako jedno z dóbr podstawowych nie stanowi warunku wszelkiego dobra, ale jedno $\mathrm{z}$ kilku równorzędnych dóbr samych w sobie ${ }^{25}$.

Autorzy zaliczani do przedstawicieli nowej koncepcji prawa naturalnego zgadzają się co do wielości i nieredukowalności dóbr podstawowych. Nie ma jednak zgody co do ich ostatecznej listy. Finnis pierwotnie wyróżniał ich siedem: życie, wiedza, zabawa, przeżycia estetyczne, życie w społeczności, rozumność praktyczną oraz religię ${ }^{26}$. W kolejnych latach dokonał ich przeformułowania, a nawet dodał do listy nowe dobro podstawowe: małżeństwo ${ }^{27}$. Inni autorzy wymieniają takie dobra podstawowe, jak: przyjemność, fizyczny i psychiczny dobrostan, pomysłowość, wewnętrzny pokój, wewnętrzną integrację ${ }^{28}$. W polskiej literaturze przedmiotu postuluje się również dodanie do katalogu „ludzkiej pracy”29.

Autorzy nie są również zgodni co do stałego charakteru dóbr podstawowych. Dominuje pogląd o ich względnej niezmienności, istnieje jednak również pogląd, w myśl którego mają one charakter dynamiczny ${ }^{30}$. Bezsporny pozostaje jednak wniosek płynący z przyjęcia wielości niezależnych dóbr podstawowych jako wskazań rozumu praktycznego. Tak jak nie istnieje jeden wspólny mianownik dla dóbr podstawowych, tak nie istnieje nadrzędny sposób oceny ludzkich zachowań realizujących różne dobra podstawowe. Zdaniem zarówno twórców omawianych teorii, jak ich komentatorów, taka ocena byłaby nieadekwatna i przypominałaby porównywanie długości do wagi $^{31}$. Oceniać ludzkie czyny możemy jedynie w relacji do pozbawionych obiektywnej hierarchii ${ }^{32}$ dóbr podstawowych, poprzez uczestnictwo w nich oraz ich respektowanie. Partycypujemy w nich, czyniąc je przedmiotem swoich działań, respektujemy, powstrzymując się od działań sprzecznych $\mathrm{z}$ nimi $^{33}$. Co interesujące, $\mathrm{w}$ literaturze wskazuje się, że ich respektowanie

24 J. Crowe, Natural Law Beyond Finnis, s. 298.

25 Zob. P. Żabieniec, Prawo rozumu. O teorii prawa naturalnego Johna Finnisa, s. 133.

26 J. Finnis, Prawo naturalne..., s. 98-101.

27 Zob. J. Finnis, Natural Law and Natural Rights..., s. 448

28 J. Crowe, Natural Law Beyond Finnis, s. 299.

29 P. Żabieniec, Prawo rozumu o teorii..., s. 140.

30 Zob. J. Crowe, Natural Law Beyond Finnis, s. 299.

31 Ibidem, s. 300.

32 Finnis w posłowiu do drugiego wydania Prawa naturalnego i uprawnienia naturalnego podjął się próby sprecyzowania zagadnienia braku hierarchii dóbr podstawowych, wskazując, że nie chodzi o jej brak, ale o brak uzasadnienia dla istnienia jednej obiektywnej hierarchii dóbr podstawowych. Takich uzasadnionych hierarchii jest wiele. Zob. J. Finnis, Natural Law and Natural Rights..., s. 450.

33 Zob. J. Crowe, Natural Law Beyond Finnis, s. 300. 
nosi znamiona obowiązku ${ }^{34}$, a zatem zbliża omawiany sposób myślenia do stanowiska deontologii.

Na to, w jaki sposób człowiek może w racjonalny sposób partycypować w dobrach podstawowych, wskazują wymogi (zasady) rozumności praktycznej, przy czym pamiętać należy, że rozumność praktyczna sama stanowi jedno $\mathrm{z}$ dóbr podstawowych ${ }^{35}$.

Istnieją zróżnicowane poglądy dotyczące zasad rozumności praktycznej, wskazać jednak należy na konsensus co do tego, że zasad tych jest więcej niż jedna $^{36}$. Mówi się, że stanowią one przejaw rozumnej autokreacji człowieka ${ }^{37}$. Każda $\mathrm{z}$ nich jest fundamentalna, niewywiedziona oraz nieredukowalna ${ }^{38}$. Finnis utożsamia je z Arystotelesowskim terminem phronimos oraz Tomaszową prudentia, wskazując, że jest to podstawowy aspekt ludzkiej pomyślności, kształtujący nasz udział w pozostałych aspektach ludzkiej pomyślności (dobrach podstawowych) ${ }^{39}$. Decydują one o moralnej ocenie ludzkich działań, a tym samym stanowią rdzeń metody prawno-naturalnej ${ }^{40}$. Człowieka kierującego się tymi zasadami Finnis określa jako posiadającego eudajmonię (w sensie samorealizacji oraz pomyślności), a zarazem wypełniającego swoją potencjalność (stającego się tym, kim może być), a zatem realizującego swoją naturę $^{41}$. Należy jednak pamiętać, że Finnis, nie negując porządku metafizycznego, wskazuje, że jego analiza opiera się na wymaganiach rozumu, nie zaś na wymaganiach natury (co pozwala mu uniknąć zarzutu popełnienia błędu naturalistycznego).

Należy wskazać, że wśród autorów utożsamianych w dyskursie naukowym $\mathrm{z}$ nową teorią prawa naturalnego nie ma zgody co do tego, czy dobra podstawowe należy respektować $\mathrm{z}$ uwagi na ich znaczenie dla podmiotu działania, czy też niezależnie od tego, kto czerpie korzyści z uczestniczenia w nich. Istnieje również pogląd, w myśl którego oba powody są uzasadnione ${ }^{42}$. W pierwszym przypadku podkreśla się rolę przyjaźni, wskazując na jej najwyższą formę, której urzeczywistnienie skutkuje wymogiem respektowania prawa innych ludzi do uczestnictwa w podstawowych dobrach. W drugim przypadku wskazuje się na obowiązek respektowania podstawowych dóbr

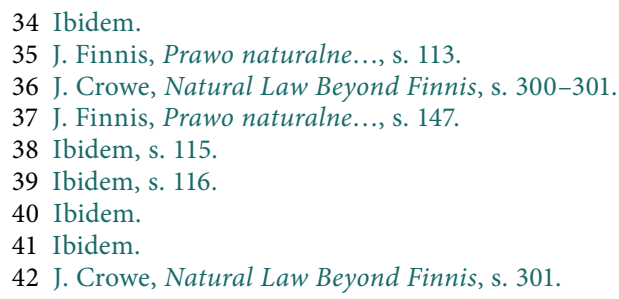

42 J. Crowe, Natural Law Beyond Finnis, s. 301. 
nie tylko w swoim życiu, ale i żywotach innych ludzi. Spór ten nie ma jednak znaczenia kluczowego $\mathrm{z}$ uwagi na to, że w obu przypadkach uznaje się, że człowiek zobowiązany jest respektować uczestnictwo innych ludzi w dobrach podstawowych oraz oczekiwać, że inni również będą respektowali dążenia pozostałych osób ${ }^{43}$.

Warto również wskazać, że przedstawiciele omawianej szkoły, w przeciwieństwie do większości przedstawicieli pozytywizmu prawnego, oceniają systemy prawa pozytywnego nie tylko z punktu widzenia ich źródła (ustanowienia przez odpowiedni autorytet prawny przy zastosowaniu odpowiedniej procedury), ale także badają, czy istnieją wystarczające racjonalne (moralne) powody do przestrzegania takiego prawa. Przy czym racjonalność regulacji prawnych może wynikać wprost z obowiązku respektowania dóbr podstawowych (na przykład penalizacja morderstw) lub z samego faktu porządkowania życia społecznego (w przypadku przepisów ruchu drogowego) ${ }^{44}$.

W literaturze przedmiotu wskazuje się, że postulat badania moralnych przesłanek dla przestrzegania prawa pozytywnego, zdaniem przedstawicieli nowej teorii prawa naturalnego, przybiera dwie zasadnicze formy. W przypadku pierwszej, wskazuje się, że norma prawa pozytywnego jest wadliwa moralnie wtedy, gdy wymaga ona od jednostki czynu, który jest sprzeczny z moralnym obowiązkiem tej jednostki. W drugim przypadku dla wykazania moralnej wadliwości normy prawa pozytywnego wystarczy wykazanie, że norma ta zobowiązuje człowieka do zachowania, do którego nie jest moralnie zobowiązany ${ }^{45}$ Różnie jest również rozumiany skutek wadliwości moralnej normy prawa pozytywnego. Według tzw. mocnej tezy prawa naturalnego normy dotknięte wadliwością moralną nie są w ogóle uważane za prawo. Według tzw. słabej tezy prawa naturalnego wadliwe moralnie normy są jedynie prawem w szczególnym (słabszym) sensie. Zróżnicowane są również poglądy co do tego, czy wadliwość moralna danej normy prawa stanowionego godzi wyłącznie w tę normę, czy też w cały system prawa stanowionego ${ }^{46}$. Warto podkreślić, że dyskusje te nie odwołują się wprost do dorobku naukowego Gustava Radbrucha oraz jego słynnej formuły lex iniustissima non est lex. Wydaje się, że stał się on autorem nieco zapomnianym w świecie anglosaskim. 


\subsection{ROZUMNOŚĆ PRAKTYCZNA JAKO KONIECZNY ELEMENT TEORII PRAWA POZYTYWNEGO}

Podkreślić należy, że istota sporu pomiędzy przedstawicielami koncepcji prawno- naturalnych a pozytywizmem prawnym dotyczy nie tyle odpowiedzi na pytanie o istnienie prawa natury, ale o to, czy prawo natury stanowi przedmiot zainteresowania prawoznawstwa. Spór dotyczy zatem pytania o to, czy prawoznawstwo może obyć się bez koncepcji rozumności praktycznej. Pomimo opisanych w poprzednich rozdziałach odstępstw Herberta Harta od klasycznych tez pozytywizmu prawnego - których istotnym elementem jest otwartość prawoznawstwa na znaczenia nadawane terminom prawa pozytywnego przez pozaprawne systemy normatywne - wydaje się, że nie zanegował on wprost poglądu, w myśl którego rozdziela się prawoznawstwo oraz koncepcję rozumności praktycznej. Nie negował on jednak możliwości takiego połączenia, na co wskazuje fakt, że zachęcał on Johna Finnisa do napisania książki właśnie na temat rozumności praktycznej (zob. przypis 243).

Za koniecznością objęcia metodą prawoznawstwa koncepcji rozumności praktycznej przemawiają dwa oczywiste argumenty. Po pierwsze, ponieważ prawo pozytywne jest tworem człowieka, to dla jego zrozumienia wymagana jest generalna teoria wyjaśniająca ludzkie działania, a zatem potrzebne są przynajmniej elementy filozofii praktycznej. Po drugie, skoro prawo reguluje ludzkie działania w sposób racjonalny, to działania te powinny być traktowane jako przedmiot rozumności praktycznej ${ }^{47}$. W literaturze przedmiotu podkreśla się, że „nie może być prawnej ani moralnej normatywności bez uwzględnienia warunków koniecznych dla sprawstwa"48. Wskazuje się, że kompletna teoria prawa powinna odpowiadać nie tylko na pytanie o to, czym jest prawo stanowione, ale również wyjaśniać obowiązek podlegania jego nakazom. Przy czym „próba wyjaśniania normatywności poprzez wcześniejsze wyłączenie wszelkich odwołań do rozumu praktycznego jest przedsięwzięciem skazanym na porażkę" ${ }^{39}$, co wyklucza normatywizm Kelsena jako sensowną próbę uzasadnienia obowiązku przestrzegania prawa.

Na postulat potrzeby włączenia do prawoznawstwa teorii rozumności praktycznej wskazuje również istota terminów teoretycznych. Finnis zauważa,

47 F. Viola, Hans Kelsen and Practical Reason, w: P. Langford, I. Bryan, J. McGarry (red.), Kelsenian Legal Science and the Nature of Law, Dordrecht 2017, s. 126.

48 Ibidem, s. 133.

49 Ibidem, s. 136 
że zarówno Hart, jak i Joseph Raz zanegowali możliwość uzyskania jednoznaczności terminów opisowych oraz wyjaśniających poprzez poszukiwanie wspólnego mianownika lub najwyższego współczynnika (co było celem m.in. Kelsena). Owa rezygnacja z jednoznaczności w praktyce sprowadza się do tego, że w przypadkach granicznych uznaje się ich problematyczność oraz wskazuje podobieństwa i różnice w stosunku do „przypadku głównego”, nie zmienia się zaś definicji samego "przypadku głównego”, odpowiadającego "głównej składowej typu idealnego" Maxa Webera. Taki zabieg pozwala, zdaniem Finnisa, wyróżnić właściwe (główne) znaczenie danego terminu oraz znaczenia peryferyjne ${ }^{50}$. Rolą teorii jest wskazanie na kryteria odróżniające właściwe znaczenie od peryferyjnych. Teoretyk musi zatem dysponować oceną ważności i znaczenia poszczególnych elementów, tzn. „Zastanowić się nad tym, co mogłoby zostać uznane za ważne i znaczące przez ludzi, których sprawy, decyzje i działania tworzą czy ustanawiają ten przedmiot" ${ }^{\text {"1 }}$. Badacz musi więc przyjąć pewien praktyczny punkt widzenia pozwalający odseparować istotne dane od nieistotnych.

Hart posługiwał się koncepcją wewnętrznego punktu widzenia, kładącej nacisk na poglądy oraz oceny użytkowników danego języka, którzy stosują reguły nie tylko z obawy przed karą czy w nadziei na uzyskanie korzyści za złamanie normy prawnej (zewnętrzny punkt widzenia), ale używają ich dla oceny własnych oraz cudzych zachowań. Finnis, zgadzając się co do zasady $\mathrm{z}$ koncepcją wewnętrznego punktu widzenia ${ }^{52}$, zauważył, że Hart niekonsekwentnie stosuje metodę dzielenia terminów teoretycznych na główne oraz peryferyjne. Nie wyróżnił on bowiem przypadku głównego oraz peryferyjnych w odniesieniu do samego terminu „wewnętrzny punkt widzenia ${ }^{53}$. Krytyka Finnisa przyjmuje postać trzech zarzutów.

Po pierwsze, Finnis zarzuca Hartowi, że opisując wewnętrzny punkt widzenia, nie wyjaśnił sytuacji przejścia od stanu przedprawnego do stanu prawnego. Przejście to może być, zdaniem Finnisa, wyjaśnione jedynie przy uwzględnieniu postawy charakteryzującej się przejawianiem troski o sposoby wyeliminowania wad przedprawnych porządków społecznych, a zatem uwzględnieniu wymagań rozumności praktycznej ${ }^{54}$. Finnis sugeruje więc, że

50 Zob. J. Finnis, Prawo naturalne..., s. 16-17.

51 Ibidem, s. 18.

52 Uwagi skierowane w stosunku do koncepcji wewnętrznego punktu widzenia Herberta Harta odnoszą się w opisanym zakresie również do prawnego punktu widzenia Josepha Raza.

53 J. Finnis, Prawo naturalne..., s. 20. Należy dodać, że to samo odnosi się do „prawnego punktu widzenia” Josepha Raza, który można uznać za wariant „wewnętrznego punktu widzenia” Harta.

54 Ibidem. 
koncepcja wewnętrznego punktu widzenia Harta jest niepełnym lub wręcz wypaczonym sposobem ukazania przypadków praktycznego punktu widzenia. Nie sposób bowiem rozważać postaw i motywacji ujętych w koncepcji wewnętrznego punktu widzenia bez zrozumienia tego, że są to przypadki praktycznego punktu widzenia, których z kolei nie sposób zrozumieć bez odwołania do koncepcji rozumności praktycznej ${ }^{55}$.

Po drugie, Finnis wskazuje, że w świecie empirycznym wyróżnia się takie ludzkie postawy, według których obowiązek podporządkowania się regułom oraz zasadom prawa stanowionego jest co do zasady wymaganiem samej rozumności praktycznej. Przypadek taki musi być uwzględniony przez teoretyka. Prawoznawstwo zatem, jeśli ma trafnie opisywać prawo, musi uwzględniać postawy nie dające się opisać inaczej niż przez odwołanie do koncepcji rozumności praktycznej ${ }^{56}$.

Po trzecie, Finnis wskazuje, w nawiązaniu do Maxa Webera, że „oceny dokonywane przez samego teoretyka stanowią niezbędny i decydujący czynnik w doborze i kształtowaniu wszelkich pojęć stosowanych w opisie takich aspektów spraw ludzkich, jak prawo czy porządek prawny" ${ }^{\prime \prime}$. Zwraca więc uwagę, że teoretyk jest w stanie w pełni uchwycić jedynie zjawiska społeczne, które $\mathrm{w}$ jego mniemaniu są $\mathrm{z}$ praktycznego punktu widzenia istotne (w sposób istotny porządkują ludzkie życie). Staje się to szczególnie widoczne, gdy teoretyk wskazuje na braki lub nieprawidłowości opisywanych porządków społecznych. Innymi słowy, teorii - jeśli ma być czymś więcej niż zbiorem luźno powiązanych faktów - musi towarzyszyć namysł nad ważnością oraz znaczeniem owych faktów, czyli namysł praktyczny. Finnis wprost wskazuje, że człowiek nie jest zdolny do osiągnięcia wiedzy „bez wstępnej konceptualizacji, a więc także bez przyjęcia jakiegoś wstępnego zbioru zasad doboru i oceny ważności pojęć, zasad wywiedzionych z jakiegoś praktycznego punktu widzenia" ${ }^{38}$. Finnis dostrzega zatem brak możliwości stworzenia teorii prawa opartej na samym opisie. W proces tworzenia teorii jak w każde racjonalne działanie człowieka - wpisane są wymogi rozumności praktycznej. Nie zmienia to jednak faktu, że dane opisowe mogą wpływać na sądy dotyczące ważności i znaczenia opisywanych zjawisk (należy mieć na uwadze, że wiedza jest $\mathrm{z}$ jednym $\mathrm{z}$ dóbr podstawowych), oraz że nie są one wydedukowane $\mathrm{z}$ ocen ${ }^{59}$.

\footnotetext{
55 Ibidem.

56 Ibidem, s. 21.

57 Ibidem, s. 22.

58 Ibidem, s. 23.

59 Ibidem, s. 24-25.
} 
Finnis, wskazując na konieczność uwzględnienia przez opisową naukę prawa praktycznych punktów wiedzenia, postuluje zatarcie granicy pomiędzy teorią prawa (prawoznawstwem) a metodą prawno-naturalną. Ta ostatnia stanowi krytykę praktycznych punktów widzenia z perspektywy rozumności praktycznej.

Autor niniejszego tekstu proponuje, aby krytykę przeprowadzoną przez Finnisa rozumieć nie jako negację filozofii Harta, ale sposób jej uzupełnienia. Nie jest ona bowiem sprzeczna z zasadniczym wywodem Harta, a stwarza możliwość racjonalnej oceny prawa stanowionego na gruncie teorii prawa. 



\section{Zakończenie}

Filozofia prawa Herberta Harta może być traktowana jako ta, która otwiera perspektywę do rozważań nad koncepcją podstawowych zasad rozumności praktycznej, a co za tym idzie, połączenia etyki oraz prawoznawstwa. Przemawia za tym zarówno analiza opublikowanych poglądów Harta, jak i jego postawa względem twórcy tzw. nowej teorii prawa naturalnego. Filozofia Harta, jako najpełniej odzwierciedlająca aspiracje pozytywizmu prawnego $\mathrm{XX}$ wieku, jednocześnie wskazuje na ograniczenia tego sposobu postrzegania zjawisk prawnych. Najistotniejszym z nich jest brak dostatecznego uzasadnienia podporządkowania się normie prawa stanowionego. Wydaje się, że zadanie to wypełnia koncepcja racjonalności praktycznej, przypomniana w oryginalny sposób przez przedstawicieli nowej teorii prawa naturalnego.

Jak zostało wskazane na przykładzie poglądów Harta, pozytywizm prawny pozwala jedynie na wybiórcze wyjaśnienie systemu prawa pozytywnego. Bez głębszej analizy filozoficznej nie sposób wytłumaczyć przyczyn ani zasadności stosowania reguł wtórnych. W żadnym razie nie wyjaśnia ich w pełni pojęcie „nawyku”, nie czyni tego także koncepcja „minimalnej treści prawa natury”. Pojęcie „nawyku” (czego dowiódł także Hart) nie wskazuje, jaki aspekt rzeczywistości (życia społecznego) jest istotnym bodźcem kreacji prawa (także wprowadzania zmian w systemie prawa stanowionego). Natomiast pojęcie „minimalnej treści prawa natury” nie może być w sposób sensowny wyjaśnione bez pogłębionej analizy filozoficznej, której pozytywiści prawni unikają. Co więcej, sprowadzanie jej do przetrwania nie wydaje się zgodne z obserwowaną rzeczywistością.

Podkreślić należy różnice pomiędzy przetrwaniem (życiem) w rozumieniu Herberta Harta a dobrami podstawowymi ukazywanymi przez zwolenników nowej teorii prawa naturalnego. Po pierwsze, „życie” wedle Harta - jak zostało wskazane - należy rozumieć jako element wspólny prawa i moralności. Dobra podstawowe są zaś koniecznym substratem sądu moralnego. Po drugie, wspomniane „życie” (chęć przetrwania) wywiedzione jest z obserwacji, zaś dobra podstawowe są oczywistym wskazaniem rozumności praktycznej (nie wymagają przeprowadzania dowodu w sensie nauk empirycznych). Po trzecie, Herbert Hart nie wyróżnia innych elementów 
prawa natury poza „życiem” (przetrwaniem). Nową teorię prawa naturalnego cechuje zaś wielość aspektów rozumności praktycznej wyrażających się w pięciu (w najbardziej rozpowszechnionej wersji) dobrach podstawowych, wśród których obok „życia” odnajdziemy takie dobra jak „zabawa”, „przeżycia estetyczne” czy „religia”.

Pomimo różnic pomiędzy filozofią Herberta Harta a nową teorią prawa naturalnego, wydaje się, że koncepcje te rozpatrywane rozdzielnie, w sposób niewystarczający wyjaśniają zjawiska prawne. Pozytywizm prawny Harta załamuje się przy próbie wyjaśnienia związków prawa z moralnością. Natomiast nowa teoria prawa naturalnego w sposób niewystarczający omawia zagadnienia z poziomu prawoznawstwa. W szczególności nie odnosi się do teorii reguł pierwotnych oraz wtórnych, której nie sposób przecenić z punktu widzenia teorii prawa pozytywnego. Ta swoista luka w odniesieniu do zagadnień z poziomu teorii prawa pozytywnego może być również podyktowana brakiem potrzeby dyskutowania rozstrzygniętych już zagadnień (co świadczy o doniosłości filozofii Harta). Jest to tym bardziej prawdopodobne, że Hart oraz Finnis znali się osobiście oraz współpracowali ze sobą. Nie należy również zapominać, że z punktu widzenia filozofii koncepcja reguł pierwotnych i wtórnych stanowi wezwanie do krytycznej postawy względem wszystkiego, „co znajduje wyraz w normatywnej terminologii zawierającej wyrazy »powinno«, »musi«, »należy«, »łłuszny« czy »zły«"1.

Podkreślić należy, że niepełny charakter filozofii Harta nie umniejsza jego aktualności. Nie sposób bowiem w sposób właściwy odnieść nowej teorii prawa naturalnego do teorii prawa pozytywnego bez znajomości koncepcji Harta. Warto również pamiętać, że zarówno Finnis, jak i inni zwolennicy nowej teorii prawa naturalnego nie zajmują się krytyką pierwotnego pozytywizmu prawnego. Tej bowiem w sposób wyczerpujący dokonał Hart² Nowa teoria prawa naturalnego nie powinna być zatem rozumiana jako ta, która powstała w opozycji do pozytywizmu prawnego, ale jako teoria uzupełniająca wyrafinowany pozytywizm prawny Herberta Harta. Filozofia tego ostatniego zaś nie może być traktowana jako nieaktualna czy błędna. Opisuje i wyjaśnia ona bowiem zjawiska prawne w sposób prawidłowy, aczkolwiek, niewątpliwie, niepełny.

Trzeba również zauważyć, że rozwój filozofii prawa jawi się na gruncie opisanych koncepcji nie jako rewolucyjny, ale ewolucyjny, co stanowi ilustrację

1 H. L. A. Hart, Pojęcie prawa, s. 86.

2 Aktualna pozostaje również krytyka Harta skierowana w stronę normatywizmu Kelsena, który wciąż jest przytaczany z uwagi na skrajny wydźwięk czystej teorii prawa. 
zapomnianej nieco tezy o jedności europejskiej myśli filozoficznej, spopularyzowanej niegdyś przez Ericha Heintla ${ }^{3}$. Filozofia prawa Herberta Harta jest zatem aktualna nie tylko $\mathrm{z}$ uwagi na wskazane wcześniej argumenty, ale również dlatego, że bez jej zgłębienia nie sposób zrozumieć stworzonych po niej koncepcji, w tym nowej teorii prawa naturalnego. 



\section{Bibliografia}

\section{KSIĄŻKI:}

Austin J., Lectures on Jurisprudence: Or The Philosophy of Positive Law, London 1885. Austin J., The Province of Jurisprudence Determined, London 1832.

Austin J. L. ', Mówienie i poznawanie: Rozprawy i wykłady filozoficzne, tłum. B. Chwedeńczuk, Warszawa 1993.

Arystoteles, Etyka nikomachejska, w: Arystoteles, Dzieła wszystkie, $t$. V, tłum. D. Gromska, Warszawa 2002.

Chojnicka K., Olszewski H., Historia doktryn politycznych i prawnych, Poznań 2004.

Coreth E., Ehlen P., Haeffner G., Ricken F., Filozofia XX wieku, tłum. M. Kalinowski, Kęty 2004.

Dworkin R., Biorac prawa poważnie, tłum. T. Kowalski, Warszawa 1998.

Finnis J., Natural Law and Natural Rights (Second Edition), Oxford 2011.

Finnis J., Prawo naturalne i uprawnienia naturalne, tłum. K. Lossman, Warszawa 2001. Francuz P., Mackiewicz R., Liczby nie wiedza, skąd pochodza. Przewodnik po metodologii i statystyce nie tylko dla psychologów, Lublin 2007.

Gaius, Instytucje, tłum. W. Rozwadowski, Poznań 2003.

Gardocki L., Prawo karne, Warszawa 2005.

Garlicki L., Polskie prawo konstytucyjne. Zarys wykładu, Warszawa 2005.

Hart H. L. A., Eseje z filozofii prawa, tłum. J. Woleński, Warszawa 2001.

Hart H. L. A., Law, Liberty and Morality, Oxford 1982.

Hart H. L. A., Pojęcie prawa, tłum. J. Woleński, Warszawa 1998.

Izdebski H., Elementy teorii i filozofii prawa, Warszawa 2008.

Izdebski H., Historia myśli politycznej i prawnej, Warszawa 2007.

Kant I., Krytyka czystego rozumu. Tom 1, tłum. R. Ingarden, Warszawa 1957.

Kant I., Krytyka praktycznego rozumu, tłum. B. Bornstein, Kęty 2002.

Kant I., Metafizyczne podstawy nauki prawa, tłum. W. Galewicz, Kęty 2006.

Kant I., Uzasadnienie metafizyki moralności, tłum. M. Wartenberg, Kęty 2001.

Kobyliński A., Problem fundamentu praw człowieka w myśli Norberta Bobbia, w: R. Moń i A. Kobyliński (red.), Prawa człowieka i świat wartości, Warszawa 2011, s. 207-219.

Kokoszczyński M., Komentarz do zat. \$155 rozporzadzenia w sprawie „Zasad techniki prawodawczej", System Informacji Prawnej LEX 2020.

Kurcz I., Psychologia języka i komunikacji, Warszawa 2005.

1 Jest to inny autor niż poprzedzający go w niniejszej bibliografii John Austin. 
Leleno-Czarnak M., Nonkonformizm jako warunek trwania demokracji, w: M. Szyszkowska (red.), Demokracja i niepospolite jednostki, Tarnów 2013, s. 322-332.

Lewandowski S., Machińska H., Malinowski A., Petzel J., Logika dla prawników, Warszawa 2003.

Łabieniec P., Prawo rozumu. O teorii prawa naturalnego Johna Finnisa, Łódź 2004.

Moń R., Warto czy należy?, Warszawa 2011.

Moore, G. E., Zasady etyki, tłum. Cz. Znamierowski, Warszawa 1919.

Morawski L., Główne problemy współczesnej filozofii prawa, Warszawa 2000.

Nęcka E., Orzechowski J., Szymura B., Psychologia poznawcza, Warszawa 2007.

Radbruch G., Ustawowe bezprawie i ponadustawowe prawo, tłum. Cz. Tarnogórski, w: M. Szyszkowska, Zarys europejskiej filozofii prawa, Białystok 2004, s. 276-286.

Sartre J. P., Egzystencjalizm jest humanizmem, tłum. J. Krajewski, Warszawa 1998.

Sartre J. P., Problem bytu i nicości. Egzystencjalizm jest humanizmem, tłum. M. Kowalska, J. Krajewski, Warszawa 2001.

Sczaniecki M., Powszechna historia państwa i prawa, Warszawa 2003.

Skowrońska-Bocian E., Prawo cywilne. Część ogólna. Zarys wykładu, Warszawa 2005.

Sójka-Zielińska K., Historia prawa, Warszawa 2005.

Sztompka P., Socjologia. Analiza społeczeństwa, Warszawa 2007.

Szyszkowska M., Etyka, Białystok 2010.

Szyszkowska M., Zarys europejskiej filozofii prawa, Białystok 2004.

Vardy P., Grosch P., Etyka. Poglady i problemy, tłum. J. Łoziński, Poznań 2010.

Viola F., Hans Kelsen and Practical Reason, w: P. Langford, I. Bryan, J. McGarry (red.), Kelsenian Legal Science and the Nature of Law, Dordrecht 2017.

Wittgenstein L., Dociekania filozoficzne, tłum. B. Wolniewicz, Warszawa 1972.

Wołodkiewicz W., Zabłocka M., Prawo rzymskie. Instytucje, Warszawa 2001.

Ziembiński Z., Logika praktyczna, Warszawa 2002.

Zirk-Sadowski M., Wprowadzenie do filozofii prawa, Kraków 2000.

\section{Czasopisma:}

Calhoun J. B., Death Squared: The Explosive Growth and Demise of a Mouse Population, „Proceedings of the Royal Society of Medicine” 1973, t. 66, s. 80-88, https://doi. org/10.1177/00359157730661p202

Crowe J., Natural Law Beyond Finnis, „Jurisprudence” 2011, t. 2, s. 293-308. https:// doi.org/10.5235/204033211798716871

Finnis J., On the Incoherence of Legal Positivism, „Notre Dame Law Review” 1999-2000, t. 75 , s. $1597-1612$.

Kozłowski T., Społeczny pozytywizm Josepha Raza, „Studia Iuridica” 1998, t. XXXVI, s. 93-101. 
Morawski L., Pozytywizm „twardy”, pozytywizm „miękki” i pozytywizm martwy, „Ius et Lex" 2003, t. 1, s. 320-345.

Waleszczyński A., Ronalda Dworkina teoria interpretacji i jej rola $w$ filozofii prawa i polityki, „Politeja” 2006, t. 2, nr 6, s. 311-329.

\section{AKTY PRAWNE I ORZECZENIA:}

Konstytucja Rzeczypospolitej Polskiej, Dz.U. 1997 nr 78 poz. 483 z późn. zm.

Ustawa z dnia 23 kwietnia 1964 r. Kodeks cywilny, tekst jednolity: Dz.U. 2019 poz. 1145 z późn. zm.

Ustawa z dnia 2 sierpnia 1997 r. Kodeks karny, tekst jednolity: Dz.U. 2020 poz. 1444.

Ustawa z dnia 4 sierpnia 1997 r. Kodeks postępowania karnego, tekst jednolity: Dz.U. 2020 poz. 30 z późn. zm.

Rozporządzenie Prezesa Rady Ministrów z dnia 20 czerwca 2002 r. w sprawie „Zasad techniki prawodawczej”, Dz.U. 2002 nr 100 poz. 908.

Postanowienie Sądu Najwyższego z dnia 7 maja 2008 r. o sygn. akt III KK 234/07, OSNKW 2008/9/69.

\section{STRONY INTERNETOWE:}

https://archive.org/stream/lecturesonjuris00campgoog\#page/n8/mode/2up

Skan książki (dostęp z dnia 01.11.2020 r.): Austin J., Lectures on Jurisprudence: Or The

Philosophy of Positive Law, London 1885.

https://archive.org/stream/provincejurispr04austgoog\#page/n9/mode/lup

Skan książki (dostęp z dnia 01.11.2020 r.): Austin J., The Province of Jurisprudence

Determined, London 1832.

http://csi.uksw.edu.pl/oprogramowanie/lex

http://droitromain.upmf-grenoble.fr/Corpus/d-50.htm\#17 



\section{Summary}

\section{TOPICAlity OF Herbert HART'S PHILOSOPHY OF LAW AS A CRITIQUE OF PRIMARY LEGAL POSITIVISM AND ITS OPENNESS TO THE CONCEPT OF PRACTICAL RATIONALITY}

Herbert Hart is the most prominent representative of so-called sophisticated legal positivism. He has made a critique of the primary legal positivism created by John Austin. His distinction between primary and secondary rules is a milestone for contemporary legal theory. It should be also noted that, in a reply on Dworkin's accusations, he agreed that the legal system also consists the principles of law. However, his theory requires additions of the concepts of practical rationality which form the basis of the so-called New Natural Law Theory.

Herbert Hart's philosophical achievements should be divided into three parts. The first is about what law is not, the second is about what law is, the third is about what a law should be.

It is impossible to overestimate the considerations included in the first part. First of all, Hart has undeniably demonstrated the falsehood of the primary (hard) legal positivism. He did it by analyzing the functioning of the applicable legal norms. His conclusions were therefore based on empirical research. The law is not an order made by sovereign, secured by coercion, and its analysis is not possible only by means of logical conclusions that do not add external content to the result of reasoning. Hart refers to the achievements of the philosophy of language. In particular, there is an interaction of legal concepts with reality and vice versa. Therefore, the dictionary of legal concepts cannot constitute a closed, separate and independent system.

Criticism of the assumptions of primitive legal positivism led Hart to make assertions about what law is. First of all, he claims that the law can be fully known only in relation to the whole of social life. Openness and context take on fundamental importance for Hart. Law ceases to be an artificial creation of an abstract sovereign and becomes an element of social life. First of all, it is open to criticism from moral, customary and other positions. Its content is also co-created by the context in which it is applied. It is interesting that Hart's theses in the scope presented above are also true in the Polish legal system. In particular, it is necessary to point out the essence of legal language, which is not a metalanguage but a register of an ethnic language. The meanings of the names contained therein often depend on the context of their use. In Poland, legal definitions are more important, but they do not constitute the 
entire legal system, which in its assumptions remains open thanks to underspecified expressions and general clauses, as well as references to legal principles, and sometimes to values. Also noteworthy is the possibility for the court to apply various methods of interpretation and the theoretical possibility of departing from the linguistic interpretation, when its effect would be contrary to generally accepted ethical norms. Hart's philosophy allows for such a judicial activity, which may be considered the most significant legacy of his achievements, because it was formulated from the perspective of legal positivism, therefore the part of philosophy of law, which was responsible for the attempt to remove axiology from the method of jurisprudence.

On the basis of undoubtedly correct observations, Hart created an extensive theory of law. However, this project did not end with full success. First of all, there are doubts about Hart's understanding of the moral norm and the features he points out to distinguish it from the legal norm. His theory is extremely important for the philosophy of law. First of all, it is a positivist theory that distances itself from the theses of its predecessor in a way that does not allow the mind applying the principles of logic to return to the assumptions of original legal positivism. Hart's theory of law should be treated not as one that would allow for a precise definition of the law, but as a theory indicating its characteristic features, without prejudging whether they are complete. Such a view is consistent with Hart's (and his scientific community) understanding of the essence of defining.

The third part of Hart's academic achievements is his concept of the minimum content of the law of nature, which gives rise to general guidelines to the content of the law. In his opinion, this concept is built on the observation based on the fact that people strive for survival, and therefore the law must ensure the possibility of implementing these aspirations. However, it is not possible to build a theory of the law of nature without adopting a series of philosophical assumptions. First of all, the assertion that there is human nature is itself a metaphysical thesis. The thesis that people should pursue the known goal of their nature is an axiological and epistemological thesis. This does not mean that these theses are wrong. But they undoubtedly exceeded the empirical method. Therefore Hart's assertion that his theory derives solely from observation is incorrect. Moreover, there is an assumption in his claims which he does not discuss. Namely, by indicating what law should be based on observation, Hart connects the sphere of being and ought, which, for example, from the point of view of Kantism, is a mistake.

Moreover, it seems that it is not "survival" that constitutes man's basic aspiration, but the will to create a culture. Survival is secondary to this. If we can talk about something that distinguishes a person in the sphere of experience, it is the processing of the existing environment, the effect of which is a survival (though not always).

Apart from the issue of what the basic human aspiration is, it is worth saying that the word "survival" is an ambiguous statement. Even accepting the fact that it is and should be a human goal, one should consider what actions will ensure its implementation. In other words, how to construct a legal system conducive to human survival. 
Hart does not answer that question. First of all, we do not find in his philosophy an answer to the question of whether, for survival, it is only necessary to ensure the realization of lower values (ensuring prosperity - utility ones), or it is necessary to refer to higher values (ideals). This is an extremely important problem because it seems that the realization of only lower (utility) values leads not to survival, but to the destruction of society. If we find that survival requires reference to higher values, the explanatory power of Hart's philosophy drops to zero. It would then only shift the problem. Instead of asking about the axiology of law, one would have to ask about the axiology of survival.

It should be pointed out that the thesis that the implementation of only lower (utility) values leads to destruction is more probable than the thesis that the implementation of these values ensures survival. If so, then the concept of the minimal content of a law of nature gives only an apparent answer. The results of the well-known Calhoun experiment on rats provide a significant indication in this regard. From the point of view of this publication, it is important that Calhoun subjected the population of rats to the experiment, providing them with the best possible conditions, in particular, unlimited food and medical care. Importantly, the rats did not populate the entire territory intended for them, so the limiting condition was not the lack of space (they voluntarily gathered in crowded selected nests - however, this is not important from the point of view of this text). At first, the rat population grew rapidly. Then population growth began to decline. Despite the availability of all resources, the population completely lost its reproductive capacity, which led to extinction. Recent mice have lost interest in procreation and got rid of aggressive behavior. The subjects were only interested in themselves. They were beautiful and healthy, but unable to take on challenges. Despite their excellent health, they did not reproduce. Interestingly, in earlier generations (when the population was still capable of reproducing), the loss of aggression and the need for domination in males was observed, and aggressive behavior was taken over by females and expressed in a pathological way (for example, towards young ones). Homosexual behavior was also common (their role increased significantly). The results of the experiment were variously interpreted. There is no doubt, however, that the lack of challenges led to the extermination of the population. The provision of unlimited resources caused the extinction before the rats could settle their entire habitat.

These arguments are not conclusive, but they justify the thesis that in order to survive, a person must be able to take up challenges - in the sense of achieving goals other than meeting biological needs. It seems, that the thesis that for human survival it is necessary to refer to higher values is probable. If so, Hart's concept is absolutely insufficient. It shifts the question about higher values to the sphere of survival. Such an explanation not solve the problem, but it blurs it.

The above thesis does not change the fact that at the description level, Hart's philosophy is a significant work. Hart made the final conclusions that could be drawn using the empirical method. First of all, he showed the flaws in the original legal positivism. However, an analysis of his positive philosophy shows that the method based on description is insufficient for considering legal phenomena. 
When answering the question about the topicality of Herbert Hart's philosophy of law, it should be said that it can be discussed at three levels of analysis.

The first level is the description level. Hart accurately and reliably analyzes the current legal phenomena. His concept is also consistent with the legal system in Poland. It is worth pointing out that, while remaining at the level of description, it is more legitimate to talk about the theory of law than about the philosophy of law. It must therefore be said that Hart's theory of law has remained relevant.

The second level of analysis are the conclusions of his theory. It indicates that the present theory implies the necessity to take into account the minimum content of the law of nature in the legal system (it is worth recalling that this system is characterized by openness, which does not correspond to the concept of a system developed by classical logic). The necessity to take into account the law of nature by the state authorities is difficult to deny. It is a universal and timeless postulate.

The third level of analysis is the perspective of the development of the philosophy of law. This perspective can be called a meta-analysis. Namely, in the contemporary philosophy of law, the boundary between legal positivism and legal-natural concepts is becoming blurred. On the one hand, legal positivism leads to the conclusion that a minimum of natural law is necessary, and on the other hand, the thesis about the invariability of its content is no longer necessarily related to the concept of natural law (an example is Radbruch's philosophy). Therefore, the assertion of a specific synthesis in the field of the philosophy of law seems to be justified.

Proposed interpretation of Hart's philosophy assumes that it includes the moral aspect of justifying the system of positive law (the minimum content of the law of nature), which is traditionally ascribed to the concepts of the law of nature and defined as the thesis about the necessary dependence of positive law on its ethical status.

These links make it necessary to base the theory of law on the concept of practical rationality. In this sense, it can be said that the need to supplement legal positivism with the concepts of practical rationality is a conclusion from the analysis of Hart's philosophy. He did not articulate such a need. Undoubtedly, however, he was open to the arguments traditionally assigned to theories of the law of nature, as evidenced not only by his concept of the minimum content of the law of nature, but also by collaboration with John Finnis.

It should be emphasized that Herbert Hart's philosophy of law undoubtedly needs to be supplemented. The main reasons for this are:

1. lack of indication and explanation of the adopted philosophical assumptions,

2. difficulties in defining the relationship between the legal and moral norm,

3. the apparent nature of "survival" as the minimum content of the law of nature,

4. lack of sufficient justification for the obligation to comply with legal norms.

It should be emphasized that the essence of the dispute between representatives of natural law concepts and legal positivism concerns not so much the answer to the question about the existence of a law of nature, but whether the law of nature is the subject of interest of jurisprudence. The dispute concerns the question whether juris- 
prudence can dispense with the concept of practical rationality. It seems that Hart did not directly negate the view according to which jurisprudence and the concept of practical rationality are separated. However, he did not deny the possibility of such a combination, as evidenced by the fact that he encouraged John Finnis to write a book on practical rationality.

There are two obvious arguments in favor of the necessity to apply the method of jurisprudence to the concept of practical rationality. First, since positive law is a human product, understanding it requires a general theory explaining human actions, and therefore at least some practical philosophy. Second, since the law regulates human actions in a rational way, these actions should be treated as an object of practical rationality. The literature emphasizes that there can be no legal or moral normativity without taking into account the conditions necessary for agency. It is indicated that a complete theory of law should answer not only the question of what statutory law is but also explain the obligation to be subject to its orders. At the same time, "an attempt to explain normativity by prior exclusion of all references to practical reason is a doomed undertaking," which rules out Kelsen's normativism as a sensible attempt to justify the obligation to obey the law.

The philosophy of Herbert Hart's law can be treated as one that opens up the prospect of considering the concept of the basic principles of practical rationality, and thus the combination of ethics and jurisprudence. This is supported by both the analysis of Hart's published views and his attitude towards the creator of the so-called new theory of natural law. Hart's philosophy as the most fully reflecting the aspirations of the 20th century legal positivism, at the same time indicates the limitations of this way of perceiving legal phenomena. The most important of them is the lack of sufficient justification for compliance with the norm of statutory law. It seems that this task is fulfilled by the concept of practical rationality, recalled in an original way by the representatives of the New Theory of Natural Law.

Herbert Hart's legal positivism allows only a selective explanation of the system of positive law. Without a deeper philosophical analysis, it is impossible to explain the causes or justification of the application of secondary rules. The concept of "the minimum content of a law of nature" cannot be meaningfully explained without an in-depth philosophical analysis that legal positivists avoid. Moreover, reducing it to "survival" does not seem to be in line with the observed reality.

It should also be noted that the development of the philosophy of law appears on the basis of the concepts described above, not as revolutionary but as evolutionary. The philosophy of Herbert Hart's law is therefore up-to-date not only because of the arguments indicated above, but also because without it, it is impossible to understand the The New Natural Law Theory. 
Mariusz Leleno-Czarnak Ukończył prawo na Uniwersyłecie Warszawskim oraz filozofię i psychologię na Uniwersytecie Kardynała Stefana Wyszyńskiego w Warszawie. W 2016 roku zdał egzamin adwokacki. Jest doktorantem na ścieżce filozoficznej w Szkole Doktorskiej Uniwersytetu Kardynała Stefana Wyszyńskiego w Warszawie.

Autor recenzowanej monografii trafnie koncentruje uwagę na fundamentalnym problemie filozoficznoprawnym, a mianowicie różnicy między prawnonaturalnym oraz pozyływistycznoprawnym pojmowaniem prawa. Przybliża ewolucję pozyływizmu prawnego, wykazując wiedzę także w dziedzinie historii filozofii prawa. Trzeba podkreślić, że prawidłowo przedstawił stanowisko Kanta, co może się przyczynić do skorygowania błędów zawartych w niektórych podręcznikach opublikowanych w ostatnich dziesięcioleciach. [...] Pragnę podkreślić trafna intencję Autora, który dostrzegając rolę pozyływizmu prawnego we współczesnej kulturze, zdaje sobie sprawę, że jest konieczne wnikliwe poznanie go, by kreować inna niż pozyływistyczna wizja świata.

prof. dr hab. Maria Szyszkowska

Pan Mariusz Leleno-Czarnak stawia ważna tezę, a mianowicie powiada on, że „prawo jest częścia kultury nakierowanej na realizację idei sprawiedliwości". Prawo ma służyć realizacji projektu ludzkiego umysłu, który zwraca się ku wartościom wyższym. [...] Zdaniem autora trzeba wyróżnić w procesie kreacji idei prawa dwa istotne elementy. Pierwszy stanowi definiowanie ideału. Drugi, choć mniej oczywisty, jest identyfikacja symboliczna, czyli określaniem tego, z jakiej perspektywy pragniemy, by oceniane były postępy naszego dażenia ku sprawiedliwości. Książka może być przydatna zarówno prawnikom, jak i filozofom (zwłaszcza ełykom) do lepszego wzajemnego zrozumienia.

ks. prof. dr hab. Ryszard Moń

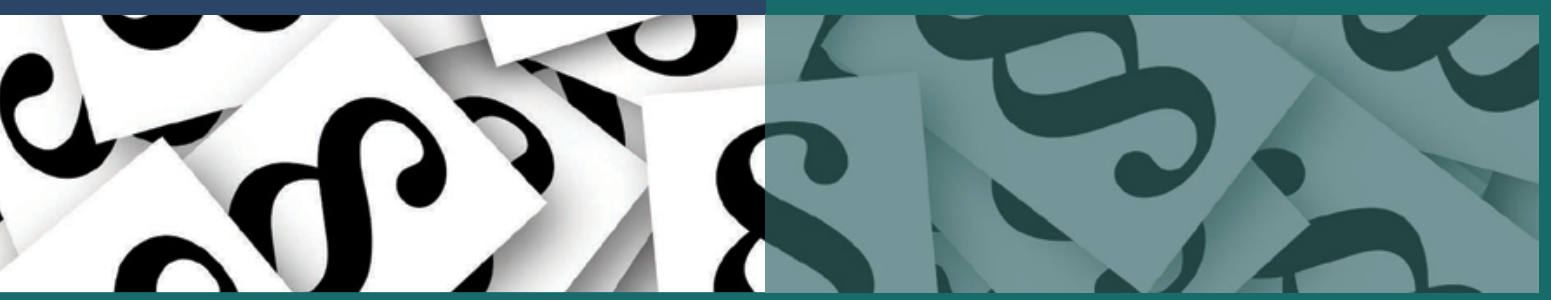

www.liberilibri.pl

ISBN 978-83-63487-49-2 